Universidade de São Paulo

Faculdade de Filosofia, Letras e Ciências Humanas

Mestrado em Ciência Política

\title{
ORDEM E REVOLUÇÃO NA REPÚBLICA DE WEIMAR
}

João Grinspum Ferraz

São Paulo

2009 
João Grinspum Ferraz

\section{ORDEM E REVOLUÇÃO NA REPÚBLICA DE WEIMAR}

Dissertação apresentada ao Programa de Pós-Graduação do Departamento de Ciência Política da Faculdade de Filosofia, Letras e Ciências Humanas da Universidade de São Paulo, sob a orientação do Prof. Dr. Oliveiros da Silva Ferreira, para a obtenção do título de Mestre.

São Paulo

2009 


\section{RESUMO}

O presente trabalho tem como objetivo discutir o pensamento e a ação dos principais grupos políticos na República de Weimar (1918-1933), bem como ambiente político em que se dá a disputa entre estes grupos. Dessa maneira, o trabalho procura classificar o papel desses grupos na disputa política de Weimar dentro das categorias de pensamento Partido da Ordem, Ordem e Revolução. O estudo leva em conta o estabelecimento de um novo cenário político na Europa após o final da I Guerra Mundial, a Conferência de Paz em Paris e a Crise Econômica que abala o continente nesse período. Esse contexto propicia o fortalecimento, na Alemanha, de grupos que se apresentam como alternativas ao modelo liberal e democrático estabelecido pela República de Weimar. De um lado, os que chamaremos de Intérpretes da Ordem - representados inicialmente por diversos grupos que, mais tarde, irão se cristalizar no Partido Nacional-Socialista (NSDAP). De outro, os partidários da Revolução - representados desde a I Guerra pela Liga Espartaquista que, em 1919, se alinhou à III Internacional Comunista depois de seu frustrado levante revolucionário. Esses grupos opostos ganham tal força no quadro político alemão que seu embate pode ser sido um dos fatores determinantes do fim do pacto originário da República de Weimar.

Palavras-chave: Alemanha, Weimar, Revolução, Ordem, Nazismo. 


\begin{abstract}
This paper aims at discussing the political thought and action of the main political groups of the Weimar Republic (1918-1933), and also the political atmosphere in which this groups fight for power. Also this paper targets to classify the role of these groups in the political dispute in the categories of Party of Order, Order and Revolution. The reference of this work is the new political framework of Europe that emerges after the First World War, The Paris Peace Conference and the Economic Crises that collapse the continent. This context benefit the empowerment of the groups that appear as an alternative of liberal and democratic model established during the Weimar Republic. On one hand there is the group that advocates in favor of the Order- at the beginning represented by several groups, but latter it will form the National Socialist Party (NSDAP). On the other hand, there is the group that wants the Revolution- represented, since the First War, by the Spartacus League which has align, in 1919, with the III International after the fail of the revolutionary uprising. Those opposite groups gain a lot of power in the German political arena and their confrontation could be the reason of the end of the pact that has origin the Weimar Republic.
\end{abstract}

Keywords: Alemanha, Weimar, Revolução, Ordem, Nazismo. 


\section{SUMÁRIO}

$\begin{array}{lr}\text { Agradecimentos } & 7\end{array}$

1. Introdução 8

1.1. A Economia e a Política em Weimar 13

2. As categorias teóricas: Partido da Ordem, Ordem e Revolução 22

2.1. O Partido da Ordem 22

2.2. A Ordem 26

2.3. A Revolução 31

3. Um só Völk, a Kultur e a Zivilisation 41

3.1. A arte na contraposição entre a vontade de potência e o Iluminismo 62

4. Socialistas versus Socialistas: Partido da Ordem e Revolução na República de Weimar $\quad 75$

4.1 O Partido da Ordem $\quad 75$

$\begin{array}{lll}4.2 & \text { A Revolução } & 87\end{array}$

5. A Ordem como proposta reorganizadora 99

$\begin{array}{ll}\text { 6. Considerações Finais } & 113\end{array}$

$\begin{array}{lll}\text { 7. } & \text { Referências } & 123\end{array}$

$\begin{array}{llr}\text { 8. Anexos } & 132\end{array}$

8.1. A Constituição da República de Weimar 132

8.2. Decreto do Incêndio do Reichstag, 28 de fevereiro de 1933

8.3. Ato do Reichstag de 23 de março de $1933 \quad 161$

8.4. Discurso de Adolf Hitler em 23 de Março de 1933 
Tabela 1. Índice de preços ao consumidor e variação anual da inflação na Alemanha entre 1912 e 1934. Índice com base no ano de 1912=100

Tabela 2. Distribuição assentos no parlamento alemão, por partido, no período entre 1919 e 1933.

Tabela 3. Distribuição votos (em porcentagem) para parlamento alemão, por partido, no período entre 1919 e 1933. 


\section{AGRADECIMENTOS}

Cabe aqui lugar para agradecimento àqueles que cooperaram de forma direta e indireta na elaboração deste trabalho. Esse trabalho nasceu fruto de um interesse antigo que alimento sobre a Segunda Guerra Mundial e tudo que envolve a história do período. Mas, do ponto de vista acadêmico, esse trabalho nasceu quando, no segundo ano do curso de Relações Internacionais, na PUC-SP, assistia as aulas da disciplina "Guerra, Poder e Geopolítica”, ministrada pelo professor Oliveiros S. Ferreira. Nesse semestre, após diversas conversas e extraordinárias aulas, passei a cercar o professor, com quem mantive o contato desde então. Graças a ele, e a sua orientação, pude transformar o que era um interesse pessoal no objeto de estudo de uma dissertação de mestrado. Fica aqui um agradecimento especial, pelo carinho e rigor com que tem me tratado, além de uma enorme paciência para com um aluno muito pouco disciplinado.

Devo também agradecer aos professores Antonio Pedro Tota, Leonel Itaussu, Cláudio Gonçalves Couto e Antonio Luis Sergio Bichir pelas inúmeras aulas, discussões e recomendações bibliográficas que fizeram com que o tema aqui estudado amadurecesse de maneira acadêmica. Aos meus pais, Isa e Marcelo, e a meu irmão Marcos pelas diversas leituras, conselhos, apoio, e todo o resto que está no plano do indizível.

E a Ju, pelas várias ajudas, comentários, e apoio sem fim ao longo do trabalho até seu estágio final.

Muito Obrigada.

João Grinspum Ferraz 


\title{
1. Introdução
}

\begin{abstract}
"No fundo da política mundial, que está longe de ser pacífica, a situação na Alemanha se destaca com nitidez. Os antagonismos políticos e econômicos atingiram nesse país uma gravidade inaudita. O desenlace se anuncia muito próximo. Está chegando o momento em que a situação pré-revolucionária tem de se transformar em situação revolucionária ou... contra revolucionária. Segundo a direção e a solução que tiver a crise alemã, a sorte não só da Alemanha (o que já seria muito), como também os destinos da Europa, os destinos do mundo inteiro, serão decididos por muitos anos" ${ }^{\text {. }}$.
\end{abstract}

(Leon Trotsky, 1930)

A história recente está marcada por grandes embates ideológicos, sejam eles no interior dos Estados, sejam eles nas relações entre Estados. Os países ocidentais, quase sem exceções, enfrentaram em seu interior disputas políticas, tentativas de golpes, revoluções, levantes, toda sorte de agitações sociais. O modelo que, em grande medida, serviu de inspiração às lutas pelo Poder no interior do Estado na primeira metade do século XX foi o da Revolução Russa de 1917. Mas o ideal da Revolução, assim como a ideologia da Conservação e da Reação, têm suas faces moldadas pelos eventos dos séculos XVIII e XIX, como a Revolução Francesa em 1789, a Revolução de 1830 na França e, principalmente, as revoluções de 1848.

A despeito do conteúdo das reivindicações de cada um dos grupos envolvidos nos diferentes processos revolucionários ocorridos na Europa no século XIX, e em todo o mundo no século XX, é possível identificar as posições distintas dos diferentes grupos em cada um desses processos. Retiram-se, assim, as peculiaridades ligadas aos processos históricos de cada país, na tentativa de observar categorias abstratas ao longo da história na luta pelo poder dentro do Estado. De um lado, há a Revolução, cujo objetivo principal é a destruição de toda a estrutura existente no Estado e na Sociedade, substituindo-a por completo, pretendendo que não se possa identificar qualquer grau de

\footnotetext{
${ }^{1}$ TROTSKY, Leon, Revolução e Contra-Revolução na Alemanha, São Paulo, Livraria Ciências Humanas, 1979, p. 25.
} 
continuidade na ordem social, política e econômica de um Estado. De acordo com Pasquino, "a tentativa, acompanhada do uso da violência, de derrubar as autoridades políticas existentes e de as substituir, a fim de efetuar profundas mudanças nas relações políticas, no ordenamento jurídico-constitucional e na esfera sócio-econômica”². De outro lado, há aquilo que Marx chamou de Partido da Ordem, cuja característica principal é a manutenção do status quo como bandeira, ou seja, nada deve mudar no que tange às relações sociais, políticas, econômicas, e religiosas. Segundo Oliveiros S. Ferreira:

“(...) o 'partido da ordem', isto é, no dizer de Marx, a 'sociedade das empresas' os defensores do status quo, é porque os que se contrapõem aos 'inimigos da sociedade' (...), os defensores da 'propriedade, família, religião e ordem' costumam associar a preservação de suas concretas e atuais condições de existência social à alegada conservação dos valores forjados ao longo da luta do Homem contra a Natureza e seus semelhantes, fazendo essa depender daquela”3.

Existe ainda outra categoria que carrega, assim como a Revolução, a bandeira da mudança, a que chamamos de Ordem e que, para efeitos de análise, fazemos questão de distinguir do Partido da Ordem. A principal característica da Ordem consiste no desejo de transformação da sociedade sem que haja uma ruptura total com o passado e com as tradições. As categorias teóricas Revolução e Ordem têm indiscutível relevância desde a Revolução Francesa de 1789.

\footnotetext{
"São, na Política, como que categorias gerais informando a ação; maneiras de ver o mundo que antecedem a tomada de decisões e condicionam não apenas essas, como toda a prática a elas subseqüente. Elaboradas teoricamente diante das solicitações da vida social, ganharam vigência teórica especialmente a partir do século XVIII, de modo particular após a Grande Revolução de 1789. São, em síntese, os dois pólos que solicitam qualquer ação política com sentido construtivo: a Ordem e a Revolução"*.
}

\footnotetext{
${ }^{2}$ BOBBIO, Norberto; MATTEUCCI, Nicola e PASQUINO, Gianfranco, Dicionário de Política - 5a Ed, Brasília, Editora Universidade de Brasília, 2000. p. 1121.

${ }^{3}$ FERREIRA, Oliveiros S., Nossa América: Indoamérica, São Paulo, Editora da Universidade de São Paulo, 1971, p. 149.

${ }^{4}$ FERREIRA, Oliveiros S., Op cit, 1971, p. 142.
} 
O estudo dessas categorias teóricas é especialmente proveitoso ao observar processos políticos ocorridos durante o século XX. As roupagens ideológicas do Comunismo, Fascismo e Nazismo dão atualidade ao estudo das categorias de Ordem, Partido da Ordem e Revolução.

\begin{abstract}
“A força mais importante do século XX foi o nacionalismo. O erro fatal ou quase fatal do comunismo, assim como da democracia, foi ignorá-lo até que fosse quase - tarde demais. O maior e mais poderoso apóstolo do nacionalismo foi Adolf Hitler”.
\end{abstract}

O tema central do presente trabalho é a análise do desenvolvimento e do embate dos representantes da Revolução, da Ordem, e do Partido da Ordem na República de Weimar. Procuraremos analisar o cenário que se estabelece no pós- Primeira Guerra e as condições sociais, econômicas e, principalmente, políticas que levaram ao fortalecimento desses três grupos no interior da Alemanha.

Para que se possa analisar de que forma o acirramento do embate entre a Ordem e a Revolução acelerou o processo de desmantelamento do Estado estabelecido na República de Weimar, será necessário antes analisar conceitualmente essas categorias, buscando situá-las no campo das Ciências Políticas.

Na Alemanha, após 1918, a Revolução parecia uma alternativa real, e foi na República de Weimar que se observou uma efervescência intelectual e cultural sem precedentes: literária, artística, científica, musical e filosófica; as alternativas políticas floresciam em todos esses campos da atividade humana. Na impossibilidade de estudar toda a Europa no período do entreguerras, a Alemanha pós-1918 é o Estado que oferece

\footnotetext{
${ }^{5}$ LUKACS, John, Op cit, 2002, p. 17.
} 
os melhores e mais profundos exemplos do clima em que vivia a Europa. Segundo Karl

Mannheim:

\begin{abstract}
“A questão fundamental eram as diferenças políticas que se desenvolveram sob a pressão dos eventos da Revolução Francesa. Diferentes formas de pensamento desenvolveram-se paralelamente,; dessa maneira podemos falar de pensamento 'liberal' e 'conservador', aos quais devemos adicionar com o passar do tempo o modo 'socialista'. Essa tendência polarizadora é especialmente característica na Alemanha. Na Alemanha sempre houve uma tendência para ir aos extremos, levando argumentos lógicos às últimas consequências - uma tendência que não existiu de maneira tão marcada em nenhum país europeu fora a Alemanha”"6.
\end{abstract}

Nos primeiros anos da nascente República de Weimar, as opções que se apresentaram no cenário político alemão eram três: a social-democracia, representando um modelo de democracia parlamentar e que colocaríamos na categoria de Partido da Ordem; a Revolução, cujo modelo bolchevique triunfara na Rússia em 1917; e um novo modelo que surgia na Europa, de características ainda pouco definidas: um governo baseado em premissas nacionalistas, um Estado forte e uma economia centralizada. Com a evolução dos acontecimentos, este novo modelo irá ocupar o papel de intérprete da Ordem.

Trotsky identifica com clareza, em 1930, a personificação da Ordem nos Nacional-Socialistas (a quem ele se refere como fascistas) como um "terceiro período" alternativo à Revolução e ao Partido da Ordem. Trotsky vê a grande burguesia como o fiel da balança entre a permanência do Partido da Ordem - onde está a SocialDemocracia - e a vitória dos intérpretes da Ordem, a nosso ver, representados pelo Nacional Socialismo, como procuraremos demonstrar. De acordo com Trotsky:

\footnotetext{
${ }^{6}$ MANNHEIM, Karl, Essays on Sociology and social psychology, London, Routledge and Kegan Paul Ltd, 1959, p.79. tradução livre de "The dividing issue was the political differences which developed under pressure of the events of the French Revolution. Different styles of thought developed along party lines, so that we can speak of 'liberal' and 'conservative' styles of thought, to which we shall later have to add the 'socialist' style. Now this polarizing tendency was specially marked in Germany. In Germany there has always existed a tendency to go extremes in pushing logical arguments to their ultimate conclusions - a tendency which has not existed in such a marked fashion in the European countries outside Germany"
} 
"Por outras palavras, a finança burguesa, no seu conjunto, oscila na apreciação da situação, ainda sem base para proclamar o advento do seu 'terceiro período', no qual a social-democracia será substituída de forma absoluta pelo fascismo, sendo que, no ajuste de contas, a social-democracia, pelos seus serviços passados, deverá sofrer com outros, como se sabe, um pogrom geral. As oscilações da grande burguesia entre a social-democracia e o fascismo - em virtude do enfraquecimento dos seus partidos principais - constituem um sintoma muito evidente de uma situação pré-revolucionária”, .

É a social-democracia que proclama a República e transfere a capital para a

cidade de Weimar. Conforme John Lukacs:

\begin{abstract}
“De cerca de 1920 a 1945(...) a história do mundo (e não apenas da Europa) foi assinalada por uma luta triangular. Havia o comunismo (...); havia a democracia parlamentar (...); e havia uma nova força histórica, inadequadamente chamada de ‘fascismo', cuja primeira incidência nacional foi a ditadura de Mussolini na Itália, mas cujo poder de atração se mostrou depois eclipsado pelo Terceiro Reich de Hitler na Alemanha, um Estado nacional-socialista que permaneceu sua principal encarnação até a derrota da Alemanha em 1945". ${ }^{\circ}$
\end{abstract}

A nova república, alicerçada num acordo entre o exército e o SPD (Partido Social-Democrata Alemão), seria consolidada pela criação de um arcabouço institucional representado pela Constituição da República de Weimar. O modelo republicano parlamentar que a social-democracia instalou veio ao encontro das idéias professadas pelas democracias vencedoras da I Guerra - França, Inglaterra e EUA - nas Conferências de Paz em Paris.

É nesse cenário que o embate entre a Revolução e a Ordem vai, gradualmente, assumir um papel preponderante: sai dos bancos do parlamento para os jornais e para as ruas, criando um clima de instabilidade social e institucional que leva à derrubada da República e do Estado instituídos em Weimar.

\footnotetext{
${ }^{7}$ TROTSKY, Leon, Op. cit, , 1979, p. 42.

${ }^{8}$ LUKACS, John, O Duelo: Churchill X Hitler, Rio de Janeiro, Jorge Zahar Editor, 2002, p. 18.
} 


\title{
1.1 A Economia e a Política em Weimar
}

Não será possível simplificar a análise dos acontecimentos ignorando outros motivos que contribuíram para o fim da República de Weimar, dentre os quais a crise monetária e econômica por que passou a Alemanha após o final da I Guerra Mundial: o fenômeno da inflação entre os anos de 1917 e 1923. Segundo o estatístico E. J. Gumbel:

\begin{abstract}
“A [Primeira] Guerra fora financiada pela inflação. A República deu continuidade ao processo inflacionário, que durou até 1923. Esse processo alcançou uma dimensão sem precedentes. De 1917 até o início de 1923, o valor do Dólar subiu de 4,2 [Marcos] para 10.000,00 [Marcos]. Não obstante, apenas nos anos de 1923, o Dólar subiu de 10.000,00 para 4,2 x 10 ${ }^{12}$. Em outras palavras, em 5 anos, o Marco Alemão caiu a $10^{12}$ parte de seu valor original. Isso criou degeneração moral, uma corrupção alastrada (um fenômeno novo na história alemã), e novos ricos de origens e fins duvidosos. Por esses motivos, grandes parcelas da população tornaram-se hostis ao governo" .
\end{abstract}

Na tabela abaixo é possível observar o crescimento da inflação no período da I

Guerra Mundial (1914-1918) e, principalmente, no período entre 1917 e 1923, a que se refere Gumbel. Para que possa ser melhor entendida, o recorte foi feito desde dois anos antes do início da Grande Guerra até o final definitivo da República de Weimar em 1934.

\footnotetext{
${ }^{9}$ GUMBEL, E. J., "Disarmament and Clandestine Rearmament under the Weimar Republic" in MELMAN, Seymour, Inspection for Disarmament. Columbia, University Press, 1958. p. 203-219. tradução livre de "The war had been financed by inflation. The Republic continued inflation, which lasted up to 1923. It reached unheard-of dimensions. From 1917 to the beginning of 1923, the dollar rose from 4.20 to 10,000 marks. However, in the single year 1923, it rose from 10,000 to $4.2 \times 10^{12}$. In other words, in five years, the mark fell to the $10^{12}$ th part of its original value. This created moral degeneration, wide-spread corruption (a new phenomenon in German history), and new riches of doubtful origin and aims. It made large parts of the population hostile to the government”.
} 
Tabela 1. Índice de preços ao consumidor e variação anual da inflação na Alemanha entre 1912 e $1934^{10}$. Índice com base no ano de 1912=100

\begin{tabular}{rrr}
\hline Ano & $\begin{array}{c}\text { Índice de preços ao } \\
\text { consumidor }\end{array}$ & $\begin{array}{c}\text { Variação anual da } \\
\text { inflação }\end{array}$ \\
\hline 1912 & 100,00 & $4,9 \%$ \\
1913 & 97,33 & $-2,7 \%$ \\
1914 & 110,00 & $13,0 \%$ \\
1915 & 150,00 & $36,4 \%$ \\
1916 & 203,33 & $35,6 \%$ \\
1917 & 214,00 & $5,2 \%$ \\
1918 & 240,67 & $12,5 \%$ \\
1919 & 433,00 & $82,0 \%$ \\
1920 & 773,33 & $76,3 \%$ \\
1921 & 1286,67 & $66,5 \%$ \\
1922 & 45666,67 & $3453,2 \%$ \\
1923 & 10146666666666,70 & $18,1 \%$ \\
1924 & 11986666666666,70 & $4,3 \%$ \\
1925 & 12500000000000,00 & $2,2 \%$ \\
1926 & 12773333333333,30 & $4,9 \%$ \\
1927 & 13393333333333,30 & $0,9 \%$ \\
1928 & 13520000000000,00 & $-0,1 \%$ \\
1929 & 13506666666666,70 & $-7,2 \%$ \\
1930 & 12533333333333,30 & $-7,6 \%$ \\
1931 & 11580000000000,00 & $-9,6 \%$ \\
1932 & 10466666666666,70 & $2,0 \%$ \\
1933 & 10673333333333,30 & $1,4 \%$ \\
1934 & 10820000000000,00 &
\end{tabular}

A inflação foi controlada por um rigoroso plano arquitetado pelo ministro Hjalmar Schacht, no final do ano de 1923. Criou-se o Rentenbank, banco encarregado da emissão de uma nova moeda, o Rentenmark, que circularia paralelamente ao Marco, mas em vez de adotar o padrão ouro, seria lastreada por uma hipoteca sobre a propriedade industrial e agrícola alemã ${ }^{11}$. Schacht adotou também uma política de restrição do crédito já no ano de 1923; em 1924 essa medida seria ampliada como uma restrição total ao crédito industrial. A política recessiva de Schacht surtiu efeito e com

\footnotetext{
${ }^{10}$ Tabela compilada a partir de: CALWER, Richard, Monatliche Ubersichten uber Lebensmittelpreise, Berlim, 1913; BRY, Gerhard, Wages in Germany 1871-1945, Princeton, 1960, p. 440-445. ; MITCHELL, B. R., European Historical Statistics, 1750-1975, Nova Iorque: Facts on File, 1980.

${ }^{11}$ THALMANN, Rita, A República de Weimar, Rio de Janeiro, Jorge Zahar, 1988, p. 47-48.
} 
financiamento externo, principalmente da Grã-Bretanha, criou-se o Reichsmark, uma nova moeda lastreada em ouro. A estabilidade obtida através do plano Schacht fez com que o país pudesse voltar a contar com o a concessão de créditos advindos do exterior. Nas palavras de Beaud:

\begin{abstract}
“Quanto ao Marco alemão, após o soçobramento de 1922-1923, ele é reconstituído om o auxílio de créditos externos, britânicos especialmente, no mesmo movimento que se desenvolveu e modernizou o aparelho industrial: durante o período de 19241930, os créditos externos obtidos pela Alemanha são duas vezes e meia superiores às reparações efetivamente pagas, o que lhe permite não somente se aprovisionar em matérias-primas, mas também reconstituir um estoque de ouro de divisas, e desenvolver seus investimentos no exterior"12.
\end{abstract}

Com a quebra da Bolsa de Nova Iorque em 1929, há uma nova crise econômica que, rapidamente, reabriu o trauma do caos econômico na sociedade alemã e contribuiu para o aumento da instabilidade política, ainda que não tenha havido inflação, conforme demonstrado na tabela acima. Os capitais de investimento internacionais, que haviam chegado à Alemanha após o final de 1923 e que haviam garantido o sucesso do plano de Schacht, desapareceram: a economia entrou em retração e o desemprego atingiu níveis altíssimos. O dinheiro se tornou mais caro e houve uma drástica redução na concessão de créditos para a atividade produtiva. A esse respeito, explica Brener:

\begin{abstract}
"Nos primeiros meses de 1929, certa de quatrocentos milhões de dólares em ouro voaram dos bancos centrais de outros países rumo a Wall Street. Só o Reichsbank, o Banco Central Alemão, perdeu 41 milhões de dólares no período e tentou estancar a hemorragia oferecendo taxas de juros mais altas, na expectativa de seduzir os investidores. O juro alto, por sua vez, torna o dinheiro mais caro e inibe os empréstimos às atividades produtivas" ${ }^{\text {"13 }}$.
\end{abstract}

As altas taxas de juros provocaram uma recessão na demanda, o que resultou em um forte processo deflacionário no período. A falta de crédito e de atividade econômica

\footnotetext{
${ }^{12}$ BEAUD, Michel, História do Capitalismo: de 1500 até os nossos dias, Brasília, Brasiliense, 1989, p. 250.

${ }^{13}$ BRENER, Jayme, 1929: A crise que mudou o mundo, São Paulo, Ática, 1996, p. 8-9.
} 
fizeram com que as indústrias buscassem ajustar a produção à demanda decrescente, o que produziu um crescimento considerável no desemprego. No momento mais agudo da crise que eclodiu em 1929, os anos de 1932 e 1933, a Alemanha tinha 44\% da sua força de trabalho desempregada. Os efeitos do caos econômico sobre o processo político eram ainda mais intensos na Alemanha: o trauma da inflação do pós-guerra e a desordem social apresentavam-se como elementos que colocavam a população contra o regime. Hobsbawm caracteriza a crise econômica como um fator fundamental na ascensão dos Nacional-Socialistas ao poder:

\begin{abstract}
“Após a recuperação econômica de 1924, o Partido dos Trabalhadores NacionalSocialistas foi reduzido a uma rabeira de 2,5 a $3 \%$ do eleitorado, conseguindo pouco mais da metade do que o pequeno e civilizado Partido Democrático alemão, pouco mais que um quinto dos comunistas e muito menos que um décimo dos social-democratas nas eleições de 1928. Contudo, dois anos depois havia subido para mais de $18 \%$ do eleitorado, tornando-se o segundo partido mais forte na política alemã. Quatro anos depois, no verão de 1932, era de longe o mais forte, com mais de $37 \%$ dos votos totais, embora não mantivesse esse apoio enquanto duraram as eleições democráticas. Está claro que foi a Grande Depressão que transformou Hitler de um fenômeno da periferia política no senhor potencial, e finalmente real, do país"14.
\end{abstract}

Com o aumento da popularidade do Partido Nacional Socialista - devido ao seu discurso contra a “desordem” instituída pela República, e favorável à criação de uma ordem institucional orgânica, baseada em um modelo de Estado forte e disciplinador os grupos conservadores, representados pelos aristocratas junkers e pelos industriais do Rühr, tentavam vencer a crise política que abalava a autoridade da República indicando Hitler para chanceler do Reich, após as eleições de 1932. Em 4 de junho de 1932, Hindenburg - que fora reeleito presidente do Reich em março do mesmo ano dissolveu o parlamento e convocou novas eleições. No mesmo mês, Hindenburg rescindiu a proibição às SA e SS, o que fez com que elas retomassem suas atividades, provocando uma onda de combates violentos entre os Nazistas, os Comunistas e os

\footnotetext{
${ }^{14}$ HOBSBAWM, Eric, A Era dos Extremos - $2^{a}$ ed,, São Paulo, Companhia das Letras, 1995. p. 132.
} 
Social-Democratas. As eleições ocorreram em 31 de julho de 1932 e registraram uma esmagadora vitória dos Nacional-Socialistas, com 230 cadeiras no Reichstag (ver tabela abaixo).

Tabela 2. Distribuição assentos no parlamento alemão, por partido, no período entre 1919 e $1933 .^{15}$

\begin{tabular}{|c|c|c|c|c|c|c|c|c|c|}
\hline Partido & $1 / 1 / 1919$ * & jun/1920 & mai/1924 & dez/1924 & mai/1928 & set/1930 & jul/1932 & nov/1932 & $\mathrm{mar} / 1933$ \\
\hline NSDAP & - & - & $32^{\text {**}}$ & $14^{* \star *}$ & 12 & 107 & 230 & 196 & 288 \\
\hline Landvolk & - & - & - & - & 9 & 19 & 1 & - & - \\
\hline WP & - & - & 7 & 12 & 23 & 23 & 2 & 1 & - \\
\hline BBB & 4 & 4 & 3 & 5 & 8 & 6 & 2 & 3 & 2 \\
\hline DNVP & 44 & 71 & 95 & 103 & 73 & 41 & 37 & 52 & 52 \\
\hline CSVd & - & - & - & - & - & 14 & 3 & 5 & 4 \\
\hline DVP & 19 & 65 & 45 & 51 & 45 & 30 & 7 & 11 & 2 \\
\hline DDP & 75 & 39 & 28 & 32 & 25 & 20 & 4 & 2 & 5 \\
\hline BVP & - & 20 & 16 & 19 & 17 & 19 & 22 & 19 & 19 \\
\hline Zentrum & 91 & 64 & 65 & 69 & 61 & 68 & 75 & 71 & 73 \\
\hline SPD & 165 & 103 & 100 & 131 & 153 & 143 & 133 & 121 & 120 \\
\hline USPD & 22 & 83 & - & - & - & - & - & - & - \\
\hline KPD & - & 4 & 62 & 45 & 54 & 77 & 89 & 100 & 81 \\
\hline Outros & 3 & 6 & 19 & 12 & 11 & 10 & 3 & 3 & 1 \\
\hline Total & 423 & 459 & 472 & 493 & 491 & 577 & 608 & 584 & 647 \\
\hline
\end{tabular}

Tabela 3. Distribuição votos (em porcentagem) para parlamento alemão, por partido, no período entre 1919 e $1933 .^{16}$

\begin{tabular}{|c|c|c|c|c|c|c|c|c|c|}
\hline Partido & $1 / 1 / 1919$ * & jun/1920 & mai/1924 & dez/1924 & mai/1928 & set/1930 & jul/1932 & nov/1932 & mar/1933 \\
\hline NSDAP & - & - & $6,55^{* *}$ & $3^{* * *}$ & 2,63 & 18,33 & 37,36 & 33,09 & 43,91 \\
\hline Landvolk & - & - & - & - & 1,89 & 3,17 & 0,25 & 0,30 & - \\
\hline WP & - & - & 1,71 & 2,29 & 4,54 & 3,95 & 0,40 & 0,31 & - \\
\hline BBB & 0,91 & 0,78 & 0,64 & 1,03 & 1,56 & 0,97 & 0,37 & 0,42 & 0,29 \\
\hline DNVP & 10,27 & 15,07 & 19,45 & 20,49 & 14,25 & 7,03 & 5,93 & 8,66 & 7,97 \\
\hline CSVd & - & - & - & - & 0,20 & 2,49 & 1,10 & 1,48 & 0,98 \\
\hline DVP & 4,43 & 13,90 & 9,20 & 10,07 & 8,71 & 4,75 & 1,18 & 1,86 & 1,10 \\
\hline DDP & 18,56 & 8,28 & 5,65 & 6,34 & 4,90 & 3,78 & 1,01 & 0,95 & 0,85 \\
\hline BVP & - & 4,39 & 3,23 & 3,74 & 3,07 & 3,03 & 3,26 & 3,09 & 2,73 \\
\hline Zentrum & 19,67 & 13,64 & 13,37 & 13,60 & 12,07 & 11,81 & 12,44 & 11,93 & 11,25 \\
\hline SPD & 37,86 & 21,92 & 20,52 & 26,02 & 29,76 & 24,53 & 21,58 & 20,44 & 18,25 \\
\hline USPD & 7,62 & 17,63 & 0,80 & 0,33 & 0,07 & 0,03 & - & - & \\
\hline KPD & - & 2,09 & 12,61 & 8,94 & 10,62 & 13,13 & 14,56 & 16,86 & 12,32 \\
\hline Outros & 0,68 & 2,30 & 6,25 & 4,15 & 4,86 & 3,02 & 0,56 & 0,61 & 0,35 \\
\hline Comparecimento & 83,02 & 79,18 & 77,42 & 78,76 & 75,60 & 81,95 & 84,06 & 80,58 & 88,74 \\
\hline Total de eleitores & $36.766 .500,00$ & $33.016 .569,00$ & $38.374 .983,00$ & $38.987 .324,00$ & $41.224 .678,00$ & $42.982 .912,00$ & $44.211 .216,00$ & $44.374 .085,00$ & $44.685 .764,00$ \\
\hline
\end{tabular}

* Eleições para a Assembléia Constituinte; **DVFP e NSDAP; *** sob a legenda NSFB.

\footnotetext{
${ }^{15}$ Fonte: Compilada a partir de: GAY, Peter, A Cultura de Weimar, Rio de Janeiro, Paz e Terra, 1978 e http://www.gonschior.de/weimar/Deutschland/Uebersicht_RTW.html, consultado em 07/07/2009, às 15h00. As legendas dos partidos tem a seguinte correspondência: SPD (Social Democracia Alemã); KPD (Partido Comunista Alemão); Zentrum (Centro Católico); NSDAP (Partido Nacional Socialista dos Trabalhadores Alemães); DVP (Partido Popular Alemão); DNVP (Partido Nacional do Povo Alemão); DDP (Partido Democrático Alemão); USPD (Partido Social Democrata Independente).

${ }^{16}$ Fonte: Compilada a partir de: GAY, Peter, A Cultura de Weimar, Rio de Janeiro, Paz e Terra, 1978 e http://www.gonschior.de/weimar/Deutschland/Uebersicht_RTW.html, consultado em 07/07/2009, às $15 \mathrm{~h} 00$.
} 
Após um desentendimento entre o chanceler von Papen e o Presidente do Reichstag, Hermann Göring, von Papen dissolveu o parlamento e convocou novas eleições para o Reichstag. Nas eleições realizadas em 6 de novembro de 1932, os nazistas perderam 34 cadeiras e 2 milhões de votos, mas continuaram como o partido majoritário no Reichstag. Por um momento, Hitler julgou a situação como o início da derrocada dos Nacional-Socialistas: o Partido tinha dificuldades em conseguir apoio financeiro devido à brutalidade dos combates que as SA e SS travavam contra seus opositores nas ruas. Um dos ideólogos do partido, Gregor Strasser, deixou a direção da organização e Joseph Goebbels, outra liderança do Partido, “temia pelo futuro"17.

O gabinete formado pelo chanceler do Reich, Franz von Papen, reunindo Junkers e grandes industriais, gozava de pouca autoridade. Em 17 de novembro, von Papen renunciou e Hindenburg, para substituí-lo, nomeou Kurt von Schleicher. Com o novo chanceler, grande parte do gabinete manteve-se a mesma. Embora tivesse renunciado, von Papen gozava de prestígio junto ao presidente Hindenburg e estava insatisfeito por estar afastado do centro de decisões. Schleicher, por sua vez, não tinha apoio sólido de nenhum dos partidos majoritários. Essa situação incitou von Papen a iniciar uma série de intrigas contra Schleicher, na tentativa de que um novo gabinete do qual ele fizesse parte - fosse formado. Hitler aparecia para esses membros da aristocracia e da indústria como uma solução ${ }^{18}$ : gozava de grande popularidade e era líder de um partido com grande expressão no parlamento. Von Papen fez de Hitler seu candidato a novo chanceler junto a Hindenburg - outros membros do círculo mais próximo a Hindenburg também viam Hitler como uma boa solução. Em 30 de janeiro de 1933, após a renúncia de Schleicher, Hindenburg nomeou Hitler como chanceler do

\footnotetext{
${ }^{17}$ GAY, Peter, A Cultura de Weimar, Rio de Janeiro, Paz e Terra, 1978, p. 183.

${ }^{18}$ A simpatia e o apoio que Hitler teve, desde 1928, do influente Industrial Alfred Hugenberg, líder do Partido Nacional do Povo Alemão (DNVP) é uma exemplo significativo de como os estratos conservadores viam Hitler com bons olhos.
} 
Reich. Von Papen seria o vice-chanceler: a aristocracia e os industriais confiaram-lhe a tarefa de controlar Hitler. Em pouco mais de um ano, a República estaria efetivamente morta. O historiador Karl Dietrich Bracher escreveu:

\begin{abstract}
“Enfatizando a 'legalidade', Hitler traçou seu caminho no governo não como o líder de uma coalizão, de uma maioria parlamentar trabalhadora (...) mas através de uma brecha autoritária na Constituição de Weimar [o artigo 48], e imediatamente começou a destruir a Constituição que ele acabar de jurar defender. Este juramento formalmente correto, ele o encarava como o símbolo e o fim de sua bem sucedida habilidade política de legalidade. Agora, a real tomada de poder começava. Agora as táticas da legalidade tinham de ser combinadas com a estratégia da revolução para formar a técnica específica de tomar o poder num tempo curto, vencer no jogo, eliminar ou arregimentar todas as defesas e forças contrárias, políticas, sociais e intelectuais"
\end{abstract}

Conforme argumenta John Lukacs, a derrocada do Estado liberal e democrático não foi um fato isolado na Alemanha, mas sim um fenômeno em grande parte causado pela conjuntura da época:

\footnotetext{
"Durante os vinte anos anteriores a 1940, a democracia parlamentar liberal fracassou e foi abandonada pelos povos da Itália, Turquia, Portugal, Espanha, Bulgária, Grécia, Romênia, Iugoslávia, Hungria, Albânia, Polônia, Estônia, Letônia, Lituânia, Áustria, Alemanha - sem falar no Japão, China e muitos países da América Central e do Sul. Essas mudanças não resultaram de pressão externa, mas de desdobramentos espontâneos. Já em 1930 parecia (e isso se deu três anos antes de Hitler chegar ao poder na Alemanha) que a ascensão das ditaduras autoritárias como conseqüência do fracasso da democracia parlamentar e capitalista era um fenômeno natural e mundial”"20.
}

No final da I Guerra Mundial, a Europa experimentou sentimentos contraditórios em relação ao bolchevismo e à URSS. Com a Revolução Russa de outubro de 1917, os partidos populares, parte dos intelectuais e vários movimentos operários na Europa (e no mundo) observavam com entusiasmo a vitória de Lênin na Rússia. Por outro lado, dentre os vencedores da I Guerra havia setores que viam a

\footnotetext{
${ }^{19}$ BRACHER, Karl Dietrich, apud GAY, Peter, Op. cit, 1978, p. 183-4.

${ }^{20}$ LUKACS, John, Op cit, 2002, p. 19.
} 
vitória bolchevique com apreensão. Desde o século XIX, a Revolução - representada primeiro pelos liberais em 1848; depois, pela Comuna de Paris e, por fim, pelos Marxistas - era tida como uma ameaça à coisa pública e à propriedade. Esse medo, claramente identificado no pensamento e na ação de setores da burguesia e da aristocracia, perpassava o Partido da Ordem na sociedade alemã, em 1918. Em 1894, Feodor von Zobeltitz escreveu:

\begin{abstract}
"Somente os filisteus a quem nada consegue despregar de sua confortável paz enquanto o telhado não lhes cair sobre a cabeça podem fechar os ouvidos ao contínuo ronco do vulcão socialista que está se formando sob a superfície da sociedade de hoje; e somente o filisteu cuja renda é reduzida por impostos pode opor-se à idéia de que um exército forte é a única proteção e a mais forte barreira ao crescimento de elementos que ameaçam o Estado. A consagração da bandeira, celebrada ontem, constitui um novo e histórico marco na defesa do governo contra a revolução. As palavras do Kaiser, que uma imprensa cega, insuflada pela paixão partidária, já começou a criticar de novo, também expressaram isso”21.
\end{abstract}

As fracassadas tentativas de Revolução, realizadas pela Liga Espartaquista de Rosa Luxembourg e Karl Liebknecht, em Berlim, e por Kurt Eisner, na Baviera, só recolocaram na ordem do dia o medo da Revolução. O fracasso da Liga Espartaquista e o assassinato de seus dois principais líderes não representaram, no entanto, o fim do movimento.

O objetivo principal do trabalho ora proposto é a análise dos atores que transitaram como representantes das categorias Partido da Ordem, Ordem e Revolução no contexto alemão. O estudo dessas categorias teóricas não se propõe a se converter em um modelo fechado, que possa resumir de maneira definitiva o processo histórico

\footnotetext{
${ }^{21}$ ZOBELTITZ, Feodor von, Chronik der Gesellshaft unter dem letzen Kaiserreich, apud ELIAS, Norbert, Os Alemães, Rio de Janeiro, Jorge Zahar Editor, 1997, p. 91.
} 
alemão; serve apenas como um instrumento de análise no intuito de auxiliar no estudo do papel das forças políticas no período.

Nesse sentido, será de extrema utilidade situar historicamente as condições políticas em que se encontra o Estado alemão após a I Guerra Mundial. Trata-se do pano de fundo que possibilitará entender com mais clareza e rigor os acontecimentos do período. Fundamental, também, será analisar, à luz das Ciências Políticas, os debates teóricos travados no período - com especial ênfase àquele travado no interior do marxismo entre reformistas e revolucionários de várias sortes. Tentaremos classificar com rigor os atores do período dentro dos conceitos de Partido da Ordem, Ordem e Revolução, ainda que estes atores possam, por vezes, não se enquadrar nessa classificação. Por outro lado, será impossível tratar de Revolução sem falar na Rússia (ou URSS), assim como não se pode falar de Liberalismo sem falar do que se passa na Inglaterra e nos EUA, ou falar na gênese da ideia de Partido da Ordem sem falar na França no século XIX. 


\title{
2. As categorias teóricas: Partido da Ordem, Ordem e Revolução
}

\subsection{O Partido da Ordem}

\begin{abstract}
"Os cavaleiros da ordem tinham intimidado com profecias dos terrores da república vermelha. Porém, os vis excessos, os horrores hiperbóreos da contrarevolução triunfante (...) caiaram de branco a 'república vermelha',’22.
\end{abstract}

O conceito de Partido da Ordem aparece com Marx nos seus trabalhos sobre a Revolução de 1848 na França, A Luta de Classes em França de 1848 a 1850, o Dezoito Brumário de Luis Bonaparte e Revolução e Contra-Revolução na Europa. De acordo com Marx, o Partido da Ordem representa a união de todos aqueles que, no quadro político de 1848, se uniram contra a Revolução proletária e as mudanças sociais mais profundas na sociedade francesa. A expressão Partido da Ordem não se refere a uma organização real, concreta. É uma classificação usada para designar a organização de segmentos altos da sociedade em torno de um mesmo propósito. O partido que Marx descreve reunia a alta burguesia, a nobreza, o clero e líderes locais, segmentos sociais interessados na manutenção do status quo. Aos quais, no calor revolucionário, com receio do rompimento das relações de propriedade privada, se juntaram os republicanos moderados. De acordo com a explicação de Hobsbawm:

\footnotetext{
“Dos principais grupos sociais envolvidos na revolução, a burguesia, como já vimos, descobriu que preferia a ordem à oportunidade de pôr em prática seu programa completo quando confrontada com a ameaça à propriedade. Quando se viram diante da revolução 'vermelha', os moderados liberais e os conservadores uniram-se. Os 'notáveis’ da França, quer dizer, as famílias respeitáveis, influentes e ricas que dirigiam os negócios políticos daquele país, deram fim a sua longa e antiga rixa entre os partidários dos Bourbons, dos Orleans, e mesmo dos que apoiavam a república, e adquiriram uma consciência de classe nacional através do emergente e novo 'partido da ordem, ${ }^{\text {,23 }}$.
}

\footnotetext{
${ }^{22}$ MARX, Karl, A Luta de classes em França de 1848 a 1850, Lisboa, Avante, 1997. p75.

${ }^{23}$ HOBSBAWM, Eric J., ,A Era do Capital - $5^{a}$ ed, Rio de Janeiro, Paz e Terra, 2000, p. 41.
} 
Para Marx, eles estariam unidos sob o lema “Propriedade, Família, Religião, Ordem!”, apesar de distinguirem-se na luta política em diferentes facções de classe, com aspirações sociais e programas políticos diferentes entre si. O Partido da Ordem tem no centro de sua conceituação, a aversão à Revolução enquanto processo de rompimento da ordem social. Seu lema, "Propriedade, Família, Religião, Ordem!", representa a defesa dos alicerces em que se assenta a sociedade. Cabe lembrar também, que a existência de um Partido da Ordem não passa pela existência formal ou física: o Partido da Ordem, encarna um estado de espírito que é a negação a um processo de mudança social. A motivação real e última desse estado de espírito consiste no temor daqueles que o defendem de que sua posição social, poder político e propriedade sejam tomadas e/ou alteradas pelo processo de transformação social, no caso a Revolução. O nascimento desse grupo, no contexto francês, de acordo com Marx, se dá na coligação entre os Orleanistas e os Legitimistas, diz Marx:

\begin{abstract}
“o partido da ordem defende o título da sua dominação comum, a república; frente aos orleanistas, os legitimistas defendem, como frente aos legitimistas os orleanistas, o status quo, a República. Todas estas fracções do partido da ordem, cada uma delas com o seu próprio rei e a sua própria restauração in petto, fazem valer alternadamente, frente aos apetites de usurpação e sublevação dos seus rivais, a dominação comum da burguesia, a forma na qual ficam neutralizadas e reservadas às pretensões particulares - $a$ República” ${ }^{\text {24 }}$.
\end{abstract}

Na França, as demandas populares em torno do Sufrágio Universal e de reformas sociais deu origem a um sangrento confronto de rua entre trabalhadores, artesãos e estudantes e a Guarda Nacional. Os populares fizeram com que o centro de Paris amanhecesse no dia 24 de fevereiro tomado por barricadas. A luta que se sucedeu entre a população, insatisfeita com a situação política e social e o governo fez com que o Rei Luís Filipe abdicasse, resultando na instalação de uma Assembléia Nacional Constituinte. Essa assembléia veio a instituir o Sufrágio Universal. Dessa maneira, os

\footnotetext{
${ }^{24}$ MARX, Karl, Op cit, 1997. p. 89.
} 
anseios de igualdade para todos pareciam entrar na pauta da breve II República

Francesa. A Assembléia Constituinte, porém, pouco caminhou no sentido de atender às reivindicações dos socialistas e operários que haviam participado diretamente da revolta de fevereiro: a composição de um Partido da Ordem representou uma contraposição às propostas de mudanças dos socialistas e operários. Segundo Marx:

"O 13 de Junho encerra o primeiro período da vida da república constitucional, a qual em 28 de Maio de 1849 alcançara a sua existência normal com a reunião da Assembléia Legislativa. Toda a duração deste prólogo é preenchida pela ruidosa luta entre o partido da ordem e a Montagne, entre a burguesia e a pequena burguesia, que se opõe em vão ao estabelecimento da república burguesa em favor da qual ela própria havia incessantemente conspirado no Governo provisório e na Comissão Executiva e pela qual, durante as jornadas de Junho, se havia fanaticamente batido contra o proletariado. O 13 de Junho quebra a sua resistência e torna a ditadura legislativa dos realistas coligados um fait accompli. A partir deste momento a Assembléia Nacional é apenas um Comitê de Salvação Pública do Partido da Ordem,"25.

O Partido da Ordem mostrou-se forte e controlou a Assembléia Constituinte.

Na explicação de Marx,

"Durante as Jornadas de Junho todas as classes e partidos se tinham unido no 'partido da ordem' contra a classe proletária, o 'partido da anarquia', do socialismo, do comunismo. Tinham 'salvado' a sociedade dos cometimentos dos 'inimigos da sociedade'. Tinham retomado e divulgado entre suas fileiras as velhas palavras de ordem da antiga sociedade 'Propriedade, família, religião, ordem’ e proclamado à cruzada revolucionária: ‘sob este signo vencerás’!”26.

A promulgação da Constituição republicana teve também outras conseqüências: significou o rompimento entre facções da burguesia que lutara pelas conquistas liberais - ou seja, por governos constitucionais, direitos civis e direitos de cidadania que garantissem igualdade de condições perante a nobreza ${ }^{27}$, ou seja, pelo

\footnotetext{
${ }^{25}$ Idem. p. 70.

${ }^{26}$ MARK, Karl, O 18 Brumário de Louis Bonaparte, Coimbra, Oficinas Gráficas, 1971, p. 27.

${ }^{27}$ no dizer de Hannah Arendt “O Grande desafio do período moderno - e seu perigo peculiar - está nisso: pela primeira vez o homem se confrontou com seu semelhante sem a proteção das condições pessoais que ostentava como diferenciadoras.” ARENDT, Hannah, “Os Judeus e a Sociedade” In Origens do
} 
instituto da livre iniciativa -, e aqueles que representavam a luta pela democracia política, igualdade social e real participação das massas no campo político, a quem podemos considerar fazendo parte do partido da Revolução. Conforme descreve Hobsbawm,

\begin{abstract}
"Durante grande parte do século XIX, portanto, a divisão era entre o partido da mudança e o da estabilidade, ou, em termos mais específicos, entre o partido do progresso e o partido da ordem. (...) Essa unidade de intenções foi aos poucos erodida pelas mudanças na estrutura de classes da sociedade. A antiga aristocracia dirigente foi substituída ou dividiu o poder com a nova burguesia dominante, que não se opunha a certo grau de mudanças radicais”.,"28
\end{abstract}

O ano de 1848 foi marcado pelas revoluções que sacudiram a Europa. A derrubada do rei Luís Felipe, na França, em fevereiro, serviu como ignição para o despontar de movimentos e agitações em lugares como Nápoles, Viena, Budapeste e Berlim, entre outros. De acordo com A. J. P. Taylor, "A revolução de 24 de fevereiro em Paris, que derrubou Luis Felipe, provocou em
toda a Alemanha ocidental o mesmo tipo de resposta que havia sido provocada
pelos eventos da grande revolução de 1789 , mas desta vez em maior escala. Em
quase todos os estados houve disputas acirradas entre governantes e o povo (...),29.

Nesse aspecto, o Partido da Ordem enquanto categoria teórica, extrapola a história francesa específica do período, remanescendo, de acordo com a definição criada por Marx, à luz dos acontecimentos ocorridos na França nas disputas entre os revolucionários de 1848 e aqueles que, segundo Marx, defendia o lema “Propriedade, Família, Religião, Ordem!”.

Totalitarismo - anti-semitismo, imperialismo, totalitarismo, São Paulo, Companhia das Letras, 2004, p. 77.

${ }^{28}$ HOBSBAWM, Eric J, O Novo Século, São Paulo, Cia das Letras, 2000, p. 103.

${ }^{29}$ TAYLOR, A. J. P., The Course of German History, Londres, Routledge Classics, 2001, p. 75. tradução livre de "The revolution of February $24^{\text {th }}$ in Paris, which overthrew Louis Philippe, evoked in all western Germany the sort of response which had been evoked by events of the great revolution of 1789, but this time on a wider scale. In almost every state there were long-standing disputes between ruler and people (...)". 
Dessa maneira, estabeleceu-se uma categoria cujo propósito principal é evitar qualquer sorte de ruptura na sociedade e em suas relações fundamentais. A manutenção da propriedade, da religião e das relações familiares, constitui uma bandeira excepcional contra ações históricas de mudança, como a Revolução.

A categoria Partido da Ordem surge, conforme apresentado, como uma contraposição a Revolução, cujo modelo se estabelece em 1789. Mas ao identificar as categorias Revolução e Ordem, conforme o modelo aqui proposto, o Partido da Ordem assume, não apenas a contraposição à Revolução, na dualidade proposta por Marx, mas sim uma contraposição à Revolução e a Ordem, vista aqui como uma terceira categoria teórica cujas mudanças propostas têm outra intensidade e característica do que a Revolução, mas afirma-se também enquanto ação histórica de transformação.

Nesse sentido, o Partido da Ordem, reveste-se de um aspecto de contraposição a qualquer mudança, seja ela Revolucionária ou, no dizer de Manheim, “evolucionária”. Essas categorias serão melhor definidas nas seções seguintes.

\title{
2.2. A Ordem
}

\begin{abstract}
"Nosso povo encontrará na defesa do que possui matéria onde empregar um espírito verdadeiramente patriótico, independente e livre. Sem dúvida, não rejeito as mudanças; mas gostaria que as mudanças fossem feitas sempre com o intuito de conservar. Ainda assim, seriam precisos grandes abusos para se lançar mão deste remédio" ${ }^{30}$.

"Uma longa cadeia de eventos, interligados como causas e efeitos, estende-se desde o presente momento até os primórdios da raça humana”31
\end{abstract}

Ao se referir ao desenvolvimento político da Inglaterra nos séculos XVII e XVIII, Karl Mannheim, refere-se a um processo “evolucionário e conservador”32,

\footnotetext{
${ }^{30}$ BURKE, Edmund, Reflexões sobre a revolução em França, Brasília, Ed Universidade de Brasília, 1997, p. 221.

${ }^{31}$ SCHILLER, Friedrich, “Was heist und zu welchem Ende studiert man Universal-geschichte?” apud ELIAS, Norbert. Op cit, 1997, p. 91
} 
comparando tal desenvolvimento com o processo revolucionário francês de 1789. É característica marcante no desenvolvimento do conceito de Ordem o caráter decisivamente evolucionário, cujo modelo inglês serve de inspiração a seu primeiro grande interprete na teoria política, Edmund Burke. Nas palavras de Burke, ao refletir sobre as semelhanças e diferenças entre o processo inglês e francês,

\begin{abstract}
"A simples idéia de fabricar um novo governo é suficiente para nos encher de repulsa e horror. Desejávamos, quando da Revolução, e desejamos ainda derivar do passado tudo o que possuímos, como uma herança legada pelos nossos antepassados. Sobre o velho tronco de nossa herança, tivemos o cuidado em não enxertar nenhuma muda estranha à natureza da árvore primitiva. Todas as reformas que fizemos até hoje foram realizadas a partir de referências ao passado; e espero, ou melhor, estou convencido de que todas as reformas que possamos realizar no futuro estão cuidadosamente construídas sobre precedentes análogos, sobre a autoridade, sobre a experiência”,33.
\end{abstract}

Esse modelo de mudança a que se refere Burke, está no centro da formação do conceito da Ordem. A noção da construção histórica aliada aos vínculos com aquilo que Burke chamou de "herança, um legado que recebemos de nossos antepassados"34 contrapõe-se de à idéia de Revolução, defendendo não a conservação do status quo, que é ao que se propõe o Partido da Ordem, mas sim a possibilidade de uma mudança engendrada pela práxis humana, no sentido evolucionário, respeitando e procurando reavivar um determinado conjunto de vínculos com alguma ordem preexistente, em princípio, superando determinada realidade em favor de uma outra. Em uma reflexão sobre a Ordem, diz Oliveiros S Ferreira:

“...um princípio que se encontra em qualquer Sociedade, independente do tipo de solidariedade que a mantém unida e da forma de organizar a existência material de seus membros; enquanto consciência da ação, é uma forma de consciência que se poderia definir como histórica, isto é, que refere a ação presente a um passado (valores, idéias e estruturas) que a inspirou e a um futuro que dela resultará, e

\footnotetext{
${ }^{32}$ Tradução livre de "evolutionary and conservative" in MANNHEIM, Karl, Op cit, p.80.

${ }^{33}$ BURKE, Edmund, Op. cit, 1997, p. 67-8.

${ }^{34}$ Idem, p. 69.
} 
enquanto consideração da totalidade, a uma totalidade que se resume no próprio processo histórico" ${ }^{35}$.

Nesse sentido é preciso considerar o reconhecimento do processo histórico pela Ordem, bem como seu olhar para o futuro, ou seja, na direção de mudanças em relação ao presente - sem que haja, é claro, grandes e bruscos rompimentos com o presente. Sendo uma concepção histórica, a Ordem tem como característica fundamental a renovação e a evolução de suas propostas e de suas características específicas, ou seja, a Ordem estará sempre condicionada ao entendimento do passado, à analise do presente e a uma idéia de futuro. Essas três condições só estarão conjugadas na medida em que haja uma constante revisão histórica, para que o passado e o presente se apresentem de maneira correta e verossímil. De acordo com Oliveiros S. Ferreira, “...seja a Ordem, seja a Revolução, ambas se afirmam como ações históricas, isto é, intervenções conscientes ou semiconscientes do homem num processo social que ele sabe, ou intui, ser histórico, donde mutante ${ }^{\text {36. }}$

O reconhecimento do caráter histórico da Ordem, fundamental em sua conformação como ponto de partida para a ação do homem, é observado de maneira clara e precisa por Mannheim, como aquilo que ele chama de "conservadorismo", contrapondo-se à idéia de manutenção do status quo, à qual ele se refere como “tradicionalismo”. A Ordem, então é observada ao mesmo tempo como um movimento dinâmico centrado no desenvolvimento - ou evolução - da sociedade. Segundo Mannheim:

"O Conservadorismo é um objetivo configurado estruturalmente, dinâmico e desenvolvido historicamente. As ações e experiências das pessoas ao agir de maneira 'conservadora' (uma maneira distinta de apenas 'tradicionalista') na medida em que, e apenas na medida em que, as pessoas incorporam a si mesmo em uma das fases de desenvolvimento desse objetivo mental e estrutural (de modo

\footnotetext{
${ }^{35}$ FERREIRA, Oliveiros S., Op cit, p. 149.

${ }^{36}$ Idem, p. 142.
} 
geral na fase contemporânea), e se comportam a partir de estruturas, apenas reproduzindo-as todas ou em partes, ou desenvolvendo-as e adaptando-as segundo situações particulares concretas" ${ }^{37}$.

Na formação do pensamento da Ordem, está a noção exata de que para que se mantenha aspectos importantes passado é preciso transformar aqueles aspectos que se apresentam falhos; resgatando elementos que possam ser úteis no passado e criando novas propostas. Hans Barth analisa bem a necessidade de realizar mudanças na sociedade no sentido de que alguns elementos importantes não sejam mudados, combatendo-se assim a idéia de um rompimento total capitaneada pela Revolução. Segundo Barth,

\begin{abstract}
"Para chegar a um termo, com novas idéias políticas e formas tradicionais que ameaçam o estado das coisas, tem se mostrado repetidamente que à mera defesa do status quo é negado o sucesso definitivo. Se essa defesa não contém novos impulsos, vigor intelectual e insights que tornem possível justificar a manutenção da ordem existente contra o ataque de idéias revolucionárias, através de uma visão mais profunda do contexto histórico e social, ela acabará por permanecer ineficaz" $^{\text {38. }}$.
\end{abstract}

Nesse aspecto, é fundamental que os intérpretes da Ordem, possam agregar ao seu programa, em aspectos específicos, a defesa de pontos semelhantes ou próximos aqueles defendidos pelos partidários da Revolução, a quem se opõem de maneira veemente. Assim sendo, será possível esvaziar parte do programa Revolucionário, na medida em que se sugere uma mudança sem a ruptura total. Dessa maneira, o programa dos intérpretes da Ordem deve prescrever a transformação sem rompimento.

\footnotetext{
${ }^{37}$ MANNHEIM, Karl, Op cit, 1959, p.97. tradução livre de "Conservatism is just such an historically developed, dynamic, objective structural configuration. People experience, and act, in a 'conservative' way (as distinct from a merely 'tradionalist' way) in so far, and only in so far, as they incorporate themselves onto one of the phases of development of this objective mental structure (usually into the contemporary phase), and behave in terms of the structure, either by simply reproducing it in whole or in part, or by developing it further by adapting it to a particular concrete situation”

${ }^{38}$ BARTH, Hans. The Idea of Order, Holanda, D. Reidel Publishing Company, 1960, p. 23. tradução livre de "For in coming to terms with new political ideas and forms that threaten the traditional state of affairs, it has shown repeatedly that mere defense of the status quo is denied decisive success. If this defense does not contain new and vigorous intellectual impulses and insights which make it possible to justify the maintenance of the existing order against the onslaught of revolutionary ideas through more profound insights into the historical and social context, it will ultimately remain ineffective”.
} 
Mais além, ao se afirmar como um programa de mudança que se opõe a Revolução, e tendo se estabelecido teoricamente a partir da contraposição à Revolução Francesa de 1789, na medida em que se assume aqui o pensamento de Burke como uma das matrizes do programa da Ordem; a Ordem assume uma posição de contrariedade evidente aos preceitos iluministas de universalidade e igualdade celebrados na Revolução Francesa, e fundados na racionalidade. A universalidade de um modelo aceitável em qualquer parte, fundamento básico da racionalidade iluminista, é minimizada pelo programa da Ordem na medida em que se afirma o caráter decisivo da "herança dos antepassados”, ao que se pode apenas referir-se a uma herança que diz respeito a cada uma das sociedades e seus antepassados. Nesse sentido Barth acrescenta:

\begin{abstract}
"Racionalismo abstrato, que vê o homem em si mesmo, isolado da multiplicidade cultural da vida civilizada da ordem hierárquica na sociedade organizada, esse racionalismo abstrato, que entende a natureza humana como sendo primordialmente 'livre-iniciativa esclarecida', reduz a estrutura social a um mecanismo. A idéia de igualdade absoluta dos homens transforma a totalidade dos cidadãos em 'uma massa homogênea'. Os apóstolos da igualdade, antagônicos à igreja e destruidores de laços religiosos, reduzem o homem, com Burke disse, 'fichas indefinidas', que só necessitam ser contadas, não pesadas. $\mathrm{O}$ aspecto de quantidade predomina sobre o aspecto de qualidade" ${ }^{\text {,39 }}$.
\end{abstract}

Ao tratar do caráter decisivamente evolucionário do processo inglês, Mannheim não perde de vista as peculiaridades do processo político na Alemanha, caracterizando-o da seguinte maneira, “A Alemanha desempenhou um papel complementar, na medida em que ela transformou o conservadorismo, orgânico, e o pensamento histórico em

\footnotetext{
${ }^{39}$ BARTH, Hans. Op. cit., 1960, p. 33. tradução livre de "Abstract rationalism, which sees man in himself isolated from the manifold conditions of cultural and civilized life from the hierarchical order within organized society, this abstract rationalism, which understand man's nature as being primarily defined by 'an enlightened self-interest', reduces social structure to a mechanism. The idea of the absolute equality of men transforms the totality of citizens into 'one homogeneous mass'. The apostles of equality, antagonistic toward the church and destructive of religious ties, reduce men, as burke once said, 'to loose counters', which need only to be counted, not weighed. The aspect of quantity predominates over the aspect of quality"
} 
uma arma, atribuindo-os lógica e coerência próprias» ${ }^{40}$. Nesse aspecto, Mannheim assume a contra-revolução na Prússia em 1848, onde a aristocracia - corporificada no Estado Maior do Exército - combateu os ímpetos liberais dos revolucionários, como o momento de formação de uma idéia conservação assumindo perspectiva histórica, controlando ao mesmo tempo a herança dos antepassados e as mudanças necessárias na sociedade. Dessa maneira podemos identificar nesse processo um estágio embrionário da idéia de Ordem. Ainda segundo Mannheim, “A contra-revolução alemã, ou o 'oposto da revolução’ (...), desenvolveu seu combate ao pensamento liberal-revolucionário através de implicações lógicas e filosóficas, de maneira mais completa do que em qualquer outro país"41. A decorrência desse desenvolvimento de que fala Mannheim ficará mais evidente e será mais claramente estudado nos capítulos subseqüentes do presente trabalho.

\subsection{A Revolução}

Quanto à Revolução, podemos situá-la, enquanto fenômeno histórico, no quadro da história da Revolução Social. Nascida com a Revolução de 1789 na França, renovada com as agitações revolucionárias de 1848 e com a Comuna de Paris e, mais do que isso, respaldada pelo arcabouço teórico que se produziu na segunda metade do século XIX. Do ponto de vista teórico, enquanto categoria abstrata de pensamento, pode-se defini-la, de acordo com o Petit Libré, como um "sistema de opiniões compostas de hostilidade

\footnotetext{
${ }^{40}$ MANNHEIM, Karl, Op cit, 1959, p.80. tradução livre de "German played a complementary role in so far as she turned conservative, organic, historical tought into a weapon, giving it at the same time an inner consistency and logic from its own".

${ }^{41}$ Idem, p. 80. tradução livre de "German counter-revolution, or the 'oposite of the revolution' (...) developed its challenge to liberal-revolutionary tought in its logical and philosophical implications more completely than in any other country".
} 
ao passado e procura de um novo porvir" ${ }^{42}$. Nesse sentido bastante amplo, a Revolução significa a mudança total de um paradigma existe para outro completamente diferente, onde não restem laços com o passado de maneira nenhuma, ou seja que se transforme uma determinada situação em outra distinta, significando a negação de uma realidade presente em favor de outra distinta.

Ao longo da historia das ciências humanas, diversos autores tentaram situar ao certo o que significa a idéia de Revolução. Esses esforços geraram um arcabouço teórico considerável em torno do termo. Já em Aristóteles pode-se encontrar a preocupação com o uso do termo Revolução. Entendendo-o como a usurpação do poder político de maneira abrupta, Aristóteles define o termo como um processo histórico que rompe com a realidade pré-existente, “As Revoluções são levadas a cabo às vezes pela força e às vezes pela fraude”, a fraude, segundo Aristóteles constitui-se em uma maneira não violenta de alterar a ordem das coisas, onde "Os cidadãos inicialmente podem ser enganosamente a concordar com uma mudança no governo, e depois são forçados a aceitá-la contra a sua vontade"43. Dessa maneira Aristóteles preocupa-se apenas com a forma como a mudança é efetuada, sem identificar a Revolução a um conteúdo ideológico, ou um programa político específico.

Outro semântico ao termo é atribuído pelo positivismo jurídico de Hans Kelsen que, da mesma maneira de Aristóteles, se abstém de conferir ao termo um programa ideológico específico. Na visão de Kelsen, onde a o Estado se funda em um ordenamento jurídico, a Revolução é a transformação ilegítima de um ordenamento jurídico existente, ou seja:

"Uma revolução no sentido amplo da palavra, compreendendo também o golpe de Estado, é toda modificação ilegítima da Constituição, isto é, toda modificação da

\footnotetext{
42 apud FERREIRA, Oliveiros S., Op cit, p. 142.

${ }^{43}$ ARISTÓTELES, Política, Brasília, UNB, 1985. p. 171.
} 
Constituição, ou a sua substituição por uma outra, não operadas segundo as determinações da mesma Constituição. Dum ponto de vista jurídico, é indiferente que esta modificação da situação jurídica seja produzida através de um emprego da força dirigida contra o governo legítimo ou pelos próprios membros deste governo, através de um movimento de massas populares ou de um pequeno grupo de indivíduos. Decisivo é o fato de a Constituição vigente ser modificada ou completamente substituída por uma nova Constituição através de processos não previstos pela Constituição até ali vigente" 44 .

Já na visão de Hannah Arendt a Revolução adquire um caráter programático mínimo, ou seja, há um objetivo pelo qual ela é feito, que é tão ou mais importante do que a usurpação do poder através de uma mudança na sociedade existente ou no ordenamento jurídico. A Revolução constitui-se como a ação violenta de transformação na ordem e no regime político visando a liberdade como fim último. Diz ela:

\begin{abstract}
"Só se pode falar em Revolução, quando a mudança se verifica com vistas a um novo início, quando se faz uso da violência para constituir uma nova forma de governo absolutamente nova e para tornar real a formação de um novo ordenamento político, e quando a libertação da opressão visa pelo menos á instauração da liberdade" 45 .
\end{abstract}

Nesse sentido, Hannah Arendt atribui, à Revolução um caráter violento e emancipatório, restringindo assim seu campo ideológico. Ao falar de "libertação da opressão” e “instauração da liberdade”, Arendt tem diante de si o pensamento iluminista em revista, especialmente no que tange a igualdade e a livre iniciativa, condição sine qua non para a liberdade do ser humano, dentro do argumento do iluminismo de modo geral. Esse trabalho de "libertação da opressão" e “instauração da liberdade”, de que fala Hannah Arendt, surge de maneira clara na história social da humanidade com a Revolução Francesa de 1789. Esse movimento é descrito por Hans Barth como:

“O princípio da individualidade espiritual e essencial do espírito é sacrificado em nome do princípio abstrato de igualdade. A transformação de uma sociedade hierarquicamente estruturada em uma massa uniforme, de isolada e indiferenciada

\footnotetext{
${ }^{44}$ KELSEN, Hans, Teoria pura do direito, 6. Ed., São Paulo, Martins Fontes, 2000. p. 233.

${ }^{45}$ ARENDT, Hannah, Sobre a Revolução, Lisboa, Relógio d’Água, 2001, p.28.
} 
concentração de poder relativo, administrado por um sistema de ajuste das pressões pela livre iniciativa leva ao necessário estabelecimento de um despotismo da razão" ${ }^{\text {.46 }}$.

É a partir de então que a associação entre Revolução e emancipação social - em ultima instancia igualdade social e econômica - se tornou freqüente e, mais do que isso, imediata. Pasquino, como vimos anteriormente (ver página 2), entende, assim como Hannah Arendt, a Revolução como um processo de mudança operado a partir da violência. Pasquino não se atém, entretanto, ao caráter emancipatório de um processo revolucionário, entendo-o como uma alteração na autoridade política e "profundas mudanças nas relações políticas, no ordenamento jurídico-constitucional e na esfera sócio-econômica" ${ }^{47}$.

Podemos entender a Revolução como um processo histórico de mudança e transformação da realidade presente, rompendo com o passado e com o ordenamento social vigente, em busca de uma nova sociedade pautada pela democracia, pela igualdade e pela eliminação da propriedade privada. Segundo Oliveiros S. Ferreira,

“A Revolução, pela atitude dos que nela crêem, nega pois a unidade e a continuidade do processo, já que o agente da ação parte do princípio de que todo o existente até o momento purificador da revolução (instituições e valores, indistintamente) deve ser negado, se não destruído, desaparecendo o ponto de origem e referência da ação política, que é o presente”48.

Dessa maneira, entenderemos a Revolução, enquanto conceito, da maneira que o faz o Petit Libré e, também, Aristóteles, ou seja, como a ruptura no estado das coisas visando um novo porvir. Nesse entendimento será descartado o caráter ideológico da idéia de Revolução a priori. Embora ao analisar uma situação concreta, em se tratando

\footnotetext{
${ }^{46}$ BARTH, Hans. Op. cit., 1960, p. 23. tradução livre de "The principle of the essential and original individuality of the living spirit is sacrificed to the principle of abstract equality. The transformation of the hierarchically structured society into a uniform mass of relatively isolated and undifferentiated concentrations of power which are linked together by the mechanical and calculable pressure and counterpressure of their self-interests leads of necessity to the establishment of a rational despotism"

${ }^{47}$ BOBBIO, Norberto; MATTEUCCI, Nicola e PASQUINO, Gianfranco, Op. cit, 2000. p. 1121.

${ }^{48}$ FERREIRA, Oliveiros S., Op cit, p. 156.
} 
de um processo eminentemente histórico, seja impossível deixar de lado o conteúdo dos grupos que professam a Revolução. Oliveiros S. Ferreira distingue a Revolução da Ordem da seguinte maneira:

\begin{abstract}
“...embora a Ordem predisponha a aceitação da "disposição das coisas segundo relações aparentes e constantes, simples ou complexas”, e a Revolução se inspire num "sistema de opiniões compostas de hostilidade ao passado e procura de um novo porvir”, ambas têm presente o problema da transformação das instituições sociais e políticas. Apenas que, enquanto a primeira condiciona essa transformação ao respeito da "razão das gerações antigas", a segunda nega o passado por inteiro e se propõe estabelecer, olhos postos no futuro, uma nova ordem a partir da concepção geral que faz do desenvolvimento do processo histórico" ${ }^{49}$.
\end{abstract}

Muito embora, ao falar de um lugar específico no continente europeu, seja de extrema dificuldade não associar a Revolução a grupos políticos específicos. A partir da Revolução Francesa de 1789, a Revolução enquanto categoria histórica, reveste-se de um programa específico, a saber, no contexto de 1789, da Igualdade, da Liberdade e da Universalidade, fundada nas idéias iluministas sobre a natureza dos homens e suas relações sociais e políticas. Sobre os direitos inerentes ao ser humano e a ausência de uma hierarquia natural entre os homens.

No que tange à história específica da Alemanha, a Revolução começa a tomar forma, como um uma categoria de consistência e presença histórica a partir de 1848. Inspirados pelas agitações revolucionárias acontecidas na França, os setores da classe média, burguesia e Intelligentsia da Prússia, e dos outros Estados germânicos, iniciaram uma série de revoltas com o intuito de por um fim ao despotismo, modelo de governos nestes Estados, celebrando os avanços do Iluminismo, como a livre-iniciativa e o sufrágio universal. Assim como na França, dentre esses setores havia aqueles cuja luta resumia-se a busca por esses avanços liberais; havia, entretanto, grupos que se destacavam buscando melhorias para a classe trabalhadora, e igualdade entre os

\footnotetext{
${ }^{49}$ Idem, p. 142.
} 
homens. Rosenberg identifica a persistência dessas idéias, ditas socialistas, ao crescimento do proletariado, cujas bandeiras, com o passar do tempo, se diferenciavam das da classe-média: "para além da classe média, o proletariado das cidades surgiu como nova entidade política pronta para lutar com a classe média contra a aristocracia governante .50.

Dentre os expoentes dessas novas idéias, estava Karl Marx, que se encontrava exilado na Inglaterra, e Ferdinand Lassale. Foi Lassale, que em 1963 fundou a Associação Geral dos Trabalhadores Alemães, primeira organização de caráter partidário representando o proletariado alemão no campo do Socialismo. Lassale era, no entanto, mais brando em suas convicções ideológicas do que Marx e Engels. Influenciados por Marx e Engels, August Bebel e Wilhelm Liebknecht fundaram em 1869 o Partido Social Democrata dos Trabalhadores Alemães (SDAP).

Lassale morreu em 1864, e em 1875 na Conferência de Gotha, os dois grupos se fundiram no Partido Socialista dos Trabalhadores Alemães (SAPD) que permaneceu ilegal até 1890, quando passou a se chamar Partido Social Democrata (SPD). A principio, Marx e Engels não concordaram com a fusão dos dois partidos, em 1875, ambos apresentavam restrições consideráveis ao socialismo de Lassale, como pode ser notada na carta de Engels a Bebel em 18 de março de 1875, a carta deixa clara também a importância da liderança ideológica de Marx e Engels, mesmo no exílio na Inglaterra, diz Engels:

"Eu devo desistir, embora praticamente cada palavra neste programa, um programa
insipidamente redigido, esteja vulnerável a crítica. E tanto é assim que, se ela for
aceita, Marx e eu não poderíamos nunca reconhecer um novo partido estabelecido
nestas bases e teremos que considerar adotar mais sérias atitudes - publicas e
privadas. Lembre-se que no extrangeiro nós somos tidos como responsáveis por
toda e qualquer declaração ou decisão do Partido Social Democrata dos

${ }^{50}$ ROSENBERG, Arthur, Op. cit., 1964, p. 2, trad livre de "behind the middle class, the proletariate of the cities emerged as a new political entity ready to fight with the middle class against the government aristocracy. Nut nevertheless it was possessed of ideals which were not those of the liberal middle class". 
Trabalhadores Alemães. (...) As pessoas imaginam que nós comandamos todo o show daqui, embora você saiba tanto quanto eu que nós quase nunca interferimos nos assuntos internos do partido, e apenas com o intuito de fazer o bem, dentro do possível, nós consideramos sermos incentivadores - e apenas incentivadores teóricos. Mas como você irá perceber, esse programa marca uma virada que pode muito bem nos forçar a renunciar a qualquer tipo de responsabilidade no que tange ao partido adotá-lo"

A partir da fusão em torno de um só grupo, em 1875, as tendências Marxistas passaram a dominar o partido. Mas a necessidade de se afirmar no jogo parlamentar do Império, fez com que ganhasse força dentro do partido - e do marxismo de modo mais amplo - correntes mais brandas, com interpretações da obra de Marx que apontavam para o socialismo como uma estrela guia para a democracia parlamentar, no intuito de se reformar o Estado sem a necessidade do rompimento total que propõe a Revolução.

Nesse sentido se destacam dois líderes do movimento social democrata que capitanearam a idéia da Reforma, Kautsky e Bernstein. Cada um em seu tempo, assumiu em suas visões sobre o Marxismo a hipótese da reforma como eixo. Essa hipótese da reforma, do jogo democrática parlamentar, se afirma na introdução de Engels à segunda edição da Luta de Classes em França de 1848 a 1850, de Marx. É nesse momento que Engels revisa a história do desenvolvimento da Revolução, propondo que a vitória da classe trabalhadora pode advir de uma fonte diferente das barricadas de 1848:

"Porém, a história também não nos deu razão e demonstrou que os nossos pontos de vista dessa altura eram uma ilusão. E foi ainda mais além: não só destruiu o nosso erro de então como revolucionou totalmente as condições em que o proletariado tem de lutar. O modo de luta de 1848 está hoje ultrapassado em todos os aspectos. (...) Com esta utilização vitoriosa do sufrágio universal entrara em

\footnotetext{
${ }^{51}$ ENGELS, Friedrich “Letter from Engels to Bebel” in BEBEL, August, Aus meinem Leben, Part 2, Stuttgart, 1911. p. xxii, trad livre de "I shall desist, although almost every word in this programme, a programme which is, moreover, insipidly written, lays itself open to criticism. It is such that, should it be adopted, Marx and I could never recognise a new party set up on that basis and shall have to consider most seriously what attitude -- public as well as private -- we should adopt towards it. Remember that abroad we are held responsible for any and every statement and action of the German Social-Democratic Workers' Party. (...) People imagine that we run the whole show from here, whereas you know as well as I do that we have hardly ever interfered in the least with internal party affairs, and then only in an attempt to make good, as far as possible, what we considered to have been blunders -- and only theoretical blunders at that. But, as you yourself will realise, this programme marks a turning-point which may very well force us to renounce any kind of responsibility in regard to the party that adopts it”.
} 
acção um modo de luta totalmente novo do proletariado, modo de luta esse que rapidamente se desenvolveu. Viu-se que as instituições estatais em que a dominação da burguesia se organiza ainda oferecem mais possibilidades através das quais a classe operária pode lutar contra essas mesmas instituições estatais”52.

De acordo com Engels, já em 1895, as cidades estão maiores, assim como as vias mais difíceis de ser obstruídas. Os exércitos experimentaram um crescimento sem precedentes e estão melhores formados, e podem dobrar em um dia, com a convocação da reserva. Mais do que isso, Engels vê no desenvolvimento de um armamento mais avançado como um aumento na disparidade entre revolucionários e exércitos estatais: “Em 1848 havia a espingarda de percussão e retrocarga; hoje existe a espingarda de repetição de reduzido calibre que alcança quatro vezes mais longe, é dez vezes mais precisa e dez vezes mais rápida do que aquela" ${ }^{33}$. Engels enxerga que o crescimento do proletariado levaria a cada vez mais vitorias no plano eleitoral, o que seria o fracasso do Partido da Ordem, que em sua visão teria que partir para o campo da luta com armas, diz Engels:

\begin{abstract}
"Quer isto dizer que no futuro a luta de ruas deixará de ter importância? De modo nenhum. Significa apenas que desde 1848 as condições se tornaram muito mais desfavoráveis para os combatentes civis, muito mais favoráveis para a tropa. (...) Compreende agora o leitor por que é que os poderes dominantes querem pura e simplesmente levar-nos para lá onde a espingarda dispara e o sabre talha? (...) A ironia da história universal põe tudo de cabeça para baixo. Nós, os "revolucionários", os "subversivos", prosperamos muito melhor com os meios legais do que com os ilegais e a subversão. Os partidos da ordem, como eles se intitulam, afundam-se com a legalidade que eles próprios criaram. Exclamam desesperados com Odilon Barrot: La legalité nous tue, a legalidade mata-nos, enquanto nós, com essa legalidade, revigoramos os nossos músculos e ganhamos cores nas faces e parecemos ter vida eterna. E se nós não formos loucos a ponto de lhes fazermos o favor de nos deixarmos arrastar para a luta de rua, não lhes restará outra saída senão serem eles próprios a romper esta legalidade tão fatal para eles" ${ }^{34}$.
\end{abstract}

A caracterização feita por Engels no escrito, não deve ser entendida como pregação pela reforma, como fariam Kautsky ou Bernstein, mas apenas uma

\footnotetext{
${ }^{52}$ ENGELS, Friedrich, "Prefácio à edição alemã de 1895” in MARX, Karl, Op cit, 1997. p. xvi.

${ }^{53}$ Idem, 1997. p. xvii.

${ }^{54}$ Ibidem, 1997. p. xvii-xviii.
} 
relativização da Revolução como modelo único de luta, o movimento marxista - na altura o SPD - não deveria desprezar a via eleitoral que se apresentava como alternativa viável. Essa idéia foi levada às ultimas conseqüências do ponto de vista teórico pelas lideranças de Kautsky e Bernstein, que passaram a ver a via Democrática, como a via genuína da emancipação da classe trabalhadora, rejeitando a revolução violenta. Essa nova interpretação da obra de Marx, gerou uma polarização e uma ruptura dentro do marxismo, e do campo da Revolução. Rosa Luxembourg, dentro do SPD, e Karl Liebknecht - filho do líder Wilhelm Liebknecht - se mantiveram de acordo com o preceito de que apenas a Revolução poderia provocar as mudanças necessárias na sociedade. Fora da Alemanha, destaca-se a figura de Lênin, que se opôs veementemente às teses reformistas de Kautsky e Bernstein.

A ruptura definitiva do SPD com a Revolução deu-se quanto, após a grande vitória eleitoral na Alemanha em 1912, em 1914 o Imperador Guilherme II solicitou ao Reichstag a ampliação dos créditos para a Guerra recém declarada. A maioria Social Democrata, influenciada pelo clima de euforia popular que tomara conta da Alemanha, optou por votar favorável aos créditos para a Guerra. Parte dos membros partido, que não concordava com a Guerra, rompeu e se desligou do partido. Entre eles estavam na linha central do partido, Bernstein e Kautsky, que participaram já em 1917 da fundação do Partido Social Democrata Independente, que acabou por se reunificar com o SPD nos anos de Weimar.

Outra facção mais a esquerda do partido, liderada por Louxembourg e Liebknecht deixou também o partido. Em 1915 eles participaram junto a outros líderes de esquerda do continente, como Lênin, da Conferência de Zimmerwald, condenando a Guerra. Essa conferência marcou a ruptura dos Social-Democratas com os Revolucionários no campo da esquerda, união que fora celebrada na Segunda 
Internacional Comunista. Após o fim da Grande Guerra, definia-se com mais clareza dentro da esquerda, e do campo socialista, o que era a Revolução, e quem a representava. 


\title{
3. Um só Völk, a Kultur e a Zivilisation
}

\begin{abstract}
“A força mais importante do século XX foi o nacionalismo. O erro fatal ou quase fatal do comunismo, assim como da democracia, foi ignorá-lo até que fosse quase - tarde demais. O maior e mais poderoso apóstolo do nacionalismo foi Adolf Hitler" ${ }^{\text {5 }}$.

"O exemplo-padrão de uma cultura de identidade, que se ancora no passado por meios de mitos disfarçados de história, é o nacionalismo. Ernest Renan observou (..), 'Esquecer, ou mesmo interpretar mal a história, é um fator essencial na formação de uma nação, motivo pelo qual o progresso dos estudos históricos muitas vezes é um risco para a nacionalidade'. As nações são entidades historicamente novas fingindo terem existido durante muito tempo. É inevitável que a versão nacionalista de sua história consista de anacronismo, omissão, descontextualização e, em casos extremos, mentiras. Em um grau menor, isso é verdade para todas as formas de história de identidade, antigas ou recentes."56.
\end{abstract}

A criação de um conjunto de símbolos que formasse um ideal de identidade do povo alemão, em torno da construção de um significado para a palavra Völk, era algo que perpassava todos aqueles envolvidos com a política e a cultura na Alemanha. A possibilidade de tornar real a idéia de uma unidade alemã reunida em torno de um único Völk, embora sempre presente no imaginário coletivo, era uma alternativa que se apresentava pouco provável: meio século antes da unificação alemã, o estadista Metternich afirmara durante o Congresso de Viena que "a idéia de 'Alemanha' e de 'um povo alemão' era uma abstração" ${ }^{\text {57 }}$.

Com o advento da República, uma antiga confrontação de diferentes maneiras de ver e se comportar frente ao Estado voltou à tona na Alemanha. De acordo com a denominação empregada por Nobert Elias, existia de um lado o código de honra dos estratos guerreiros e, de outro lado, o código moral das classes médias. Explica Elias:

\footnotetext{
${ }^{55}$ Idem, p. 17.

${ }^{56}$ HOBSBAWM, Eric J. “Não basta a história de Identidade”. In Sobre História, São Paulo, Cia das Letras, 2000, p 285.

${ }^{57}$ EKSTEINS, Modris, Op. cit., 1991. p. 93
} 
"Seja qual for o caso a este respeito, a comparação do código de honra dos estratos guerreiros com o código moral das classes deixa claro por que o primeiro está tão intimamente associado com uma estrutura de poder que assenta em rigorosa hierarquização das relações humanas, ao passo que o segundo, o código da moralidade da classe média, parece formular de maneira explicita a pretensão de ser universalmente válido e, assim, de maneira implícita, expressar o postulado da igualdade de todos os seres humanos" ${ }^{\prime 58}$.

A contraposição entre essas duas visões de mundo está intimamente relacionada com o projeto Iluminista, vitorioso com a Revolução Francesa de 1789, que preponderou na Europa ocidental no século XIX. Sob a égide do Iluminismo, novos padrões sociais e morais foram inseridos na gramática política ocidental. Conforme Hobsbawm:

“(...) projeto do Iluminismo do século XVIII, a saber, o estabelecimento de um sistema universal de tais regras e normas de comportamento moral, corporificado nas instituições dos Estados e dedicado ao progresso racional da humanidade: à Vida, Liberdade e Busca da Felicidade, à Igualdade, Liberdade e Fraternidade(...) $)^{\text {59 }}$.

Na Prússia do século XIX, entretanto, era capitaneado pela nobreza um movimento contra o conjunto de idéias do Iluminismo, um movimento com um tom Romântico anti-racionalista, pouco preocupado com o que se estendia para além das fronteiras de onde estavam os povos de língua germânica - contrapondo-se ao universalismo iluminista - e contrário ao espírito de igualdade dos revolucionários franceses. Como explica Modris Eksteins:

\footnotetext{
“Ora, havia certamente um padrão bem estabelecido no passado alemão de tomar o mundo exterior, as impressões dos sentidos, da realidade visível, e relegá-los a uma posição de importância secundária frente ao mundo do espírito, da vida interior e da 'verdadeira liberdade",,60.
}

\footnotetext{
${ }^{58}$ ELIAS, Norbert, Op cit, 1997, p. 97.

${ }^{59}$ HOBSBAWM, Eric J, “Barbárie: Manual do Usuário”, In: Op. cit, p. 269.

${ }^{60}$ EKSTEINS, Modris, Op. cit., 1991. p. 95
} 
O reconhecimento do exército como fundamento de unidade e força da nação, combinava-se com os símbolos que o Romantismo buscava resgatar na Idade Média. O movimento Romântico procurava devolver à idéia de “uma Alemanha” uma dignidade aparentemente tomada pela fragmentação do povo alemão em diversos Estados após a Guerra dos Trinta Anos e as Guerras Napoleônicas. O Congresso de Viena criara em 1815, a Confederação alemã, composta por 39 Estados germânicos, onde sobressaiam o Império Austro-Húngaro e a Prússia.

O Exército, portanto, era o eixo central da construção do sentimento de unidade nacional. Representava uma tradição que remontava às Guerras Napoleônicas, após a derrota para a França em Jena e Auesrtedt, em 1806 o exército da Prússia passou por uma importante reorganização levada a cabo pelo General Scharnhorst, que empreendia uma mudança na relação entre o exército e a sociedade na Prússia. O fato de todo homem alemão servir ao Exército era um importante elemento de construção do indivíduo. Era no Exército que o homem adquiria, através da apropriação código de honra da aristocracia militar, o sentimento de disciplina, respeito à hierarquia e obediência. Sobre a unidade fundamental do espírito alemão em torno da disciplina e do exército, Elias Canetti reflete:

\footnotetext{
"O símbolo de massa dos alemães era o exército. O exército, porém, era mais do que um exército: era a floresta em marcha. Em nenhum país moderno do mundo o sentimento pela floresta manteve-se tão vivo quanto na Alemanha. O caráter rígido e paralelo das árvores eretas, sua densidade e seu número impregnam o coração do alemão de profunda e misteriosa alegria" ${ }^{61}$.
}

Friedrich Engels descreve o funcionamento do exército e nota, em 1870, como os valores desse código de honra da aristocracia são passados para aqueles que servem ao exército:

\footnotetext{
${ }^{61}$ CANETTI, Elias, Op. cit, 1995, p. 171.
} 
"O seu [da Alemanha] sistema militar atual, que divide toda a população masculina em duas partes - um exército permanente em serviço e um outro exército permanente de licença, ambos igualmente obrigados em obediência passiva a governantes de direito divino — um tal sistema militar, evidentemente, é uma 'garantia material' para preservar a paz e o fim último das tendências civilizadoras! Na Alemanha, como em qualquer outra parte, os sicofantas dos poderes vigentes envenenam o espírito popular com o incenso do auto louvor mendaz"62.

O ano de 1848 foi, também, um ano fundamental para a história e formação da Alemanha. No dizer de A. J. P. Taylor, "O evento realmente decisivo de 1848 foi a Revolução em Berlim; tornou viável a existência do Liberalismo alemão, o fim da Revolução colocou um ponto final no Liberalismo "63.

A revolução, em Berlim, comandada por políticos e profissionais liberais que representavam a nova burguesia contra a dominação política dos Junkers e da aristocracia militar prussiana, durou pouco. Ainda que não trouxessem consigo forças novas para o cenário político, a Revolução e o liberalismo alemão foram logo esmagados pela retomada do poder pelos Junkers e pela aristocracia militar prussiana. O historiador Arthur Rosenberg notou:

“A Revolução de 1848-9 mostrou que a classe média alemã não era capaz de conquistar [o Estado] apenas com sua força. Os grupos agrários e militares, dinásticos e burocráticos, e mesmo clericais, da antiga ordem na Alemanha eram muito mais fortes do que aparentaram nos dias de excitação em março de 1848 ״,64.

De acordo com Engels, a Burguesia prussiana tinha o temor de que a revolta se radicalizasse como ocorreu na França. Segundo ele, ao receber a notícia de que

\footnotetext{
62 ENGELS, Friedrich. A Guerra dos Camponeses Alemães, Lisboa, Progresso, 1982, p. II.

${ }^{63}$ TAYLOR, A. J. P., Op cit, 2001, p. 95. tradução livre de "The really decisive event of 1848 was the revolution in Berlin; this alone made possible the brief career of German liberalism, and the ending of the Prussian revolution brought this career to a close".

${ }^{64}$ ROSENBERG, Arthur, Imperial Germany: The Birth of the German Republic 1871-1918, Boston, Beacon Press, 1964, p. 2, trad livre de "The Revolution of 1848-9 showed that the German middle class was not capable of conquering by its own strength alone. The agrarian and military, the dynastic and bureaucratic, and even the clerical, elements in the old order in Germany were far stronger than it first appeared in the excitement of the March days of 1848”.
} 
Metternich fora derrubado na Áustria, o rei da Prússia resolveu fazer concessões que satisfizeram à burguesia, diz Engels:

\begin{abstract}
“Ora, a burguesia prussiana tinha tido, nos últimos tempos, bastante agitação da classe operária no seu próprio país. Depois do primeiro terror dos motins da Silésia ter desaparecido, chegou mesmo a tentar dar a essa agitação um aspecto que lhe fosse favorável; mas sempre tinha conservado um horror salutar pelo socialismo e pelo comunismo revolucionários; e, deste modo, quando viu à cabeça do governo em Paris homens que ela considerava como os mais perigosos inimigos da propriedade, da ordem, da religião, da família e dos outros penates do burguês moderno, prontamente sentiu um considerável arrefecimento do seu próprio ardor revolucionário. Sabia que o momento tinha de ser aproveitado e que sem a ajuda das massas trabalhadoras seria derrotada; e, contudo, faltou-lhe a coragem. Deste modo, pôs-se ao lado do governo nos primeiros levantamentos parciais e provinciais, tentou manter calmo o povo de Berlim, que durante cinco dias se concentrou em multidões diante do palácio real para discutir as notícias e reclamar mudanças no governo; e quando, por fim, depois das notícias da queda de Metternich, o rei fez algumas ligeiras concessões, a burguesia considerou a revolução como completada e foi agradecer a Sua Majestade por ter satisfeito todos os desejos do seu povo" ${ }^{\prime \prime 5}$.
\end{abstract}

Depois disso, os liberais passaram a ter cada vez menos importância no cenário político alemão. Dessa maneira, o Rei manteve-se no poder no reino da Prússia, e junto ao rei toda a aristocracia Junker, com seu caráter decisivamente anti-racionalista. No Estado Maior do exército as relações não se alteraram também, e a nobreza manteve a exclusividade das altas patentes do exército - o exército que tinha um Estado mantevese firme no controle da ordem social e da supremacia na Prússia. De acordo com Engels, "Esta nobreza feudal, então extremamente numerosa e em parte muito rica, era considerada, oficialmente, como o primeiro "estado" do país. Fornecia os funcionários superiores do governo, comandava quase exclusivamente o exército”66. Essa aristocracia junker, cuja origem remonta ao sistema feudal, manteve-se no comando do Estado Maior e no poder político na Prússia, após o fracasso da Revolução alemã de 1848, segundo Engels:

\footnotetext{
${ }^{65}$ ENGELS, Friedrich. Revolução e Contra-Revolução na Alemanha, Lisboa, Progresso, 1982. p. 83.

${ }^{66}$ ENGELS, Friedrich. Op. cit, 1982. p. 101.
} 
"Nem um único burocrata ou oficial do exército foi expulso; não se fez a menor alteração no antigo sistema burocrático da administração. Estes preciosos ministros constitucionais até reintegraram nos seus lugares aqueles funcionários que o povo, no primeiro calor do ardor revolucionário, tinha expulso em virtude dos seus actos anteriores de autoritarismo burocrático. Nada se alterou, na Prússia, a não ser as pessoas dos ministros; não se tocou sequer nos quadros ministeriais nos diferentes departamentos (...)" ${ }^{\text {67 }}$.

Foi sob a liderança do Junker Otto von Bismarck, chanceler da Prússia que a Prússia comandou a Unificação Alemã. Entre 1862 e 1871, Bismarck arquitetou uma série de Guerras - criando inclusive condições para que elas ocorressem -, arranjos, tratados e negociações para conseguir, em 1871, coroar o rei da Prússia como Imperador do Reich Alemão. Após as vitórias contra a Dinamarca e a Áustria, a vitória na Guerra Franco-Prussiana foi, então, o marco da Unificação Alemã e da ascensão da Alemanha unificada à condição de potência dominante na Europa continental. Segundo A. J. P. Taylor,

“os príncipes germânicos foram induzidos por Bismarck a oferecer a coroa da Alemanha a Guilherme I, e em 18 de janeiro de 1871 o Império Alemão foi proclamado no palácio de Versalhes. No espaço de nove anos, entre 1862 e 1871, a Prússia passou da mais fraca e menos temida das grandes potências para se tornar o Estado mais dominante da Europa continental”.,68

O Estado que se formava tinha entre suas características a marcada autoridade do Imperador, que era também o comandante em chefe das Forças Armadas. Segundo Rosenberg:

“O Império de Bismarck e as Forças Armadas da Prússia formavam uma entidade indissolúvel. (...) Bismarck escolheu outro caminho. Ele uniu a aristocracia militar

\footnotetext{
${ }^{67}$ ENGELS, Friedrich. Op. cit, 1982. p. 111.

${ }^{68}$ TAYLOR, A. J. P., Op cit, 2001, p. 125. tradução livre de "the German princês were induced by Bismarck to offer the German crown to William I, ando n January 18th, 1871, the German Empire was proclaimed in the palace of Versailles. Within nine years, between 1862 and 1871, Prussia had risen from being the weakest and least regarded of the Great Powers to become the dominant state of the European continent”.
} 
da Prússia com a classe média Alemã, colocou os Hohenzollerns no comando do edifício e assim deu ao Império sua marca peculiar." ${ }^{\text {. }}$.

Com a unificação alemã, realizada em 1871, os liberais têm sua importância na vida política alemã cada vez mais diminuída, ocupando um espaço no parlamento apenas, a marca do Império é, sem dúvida, a vitória de um projeto da nobreza militar, segundo Norbert Elias,

\begin{abstract}
"O fracasso dos esforços de sua própria classe [a burguesia] para realizar seu ideal de uma Alemanha unida, e a experiência de tê-lo conseguido sob a liderança da nobreza militar, levou a um desfecho que talvez possa ser descrito como a capitulação de vastos círculos da classe média à aristocracia. Eles trocavam agora, decisivamente, o idealismo burguês clássico pelo manifesto realismo de poder”.,70
\end{abstract}

A divisão federativa dos Länder do nascente Império Alemão respeitava as fronteiras dos antigos Estados que agora formavam o Império. Dessa maneira, o fato de o Imperador ser o rei da Prússia se fez presente na maneira em que Bismarck garantiu o peso maior da Prússia na divisão federativa. No Exército do novo Império, as altas patentes continuavam reservadas à aristocracia prussiana. Ainda de acordo com o historiador Rosenberg, “No estabelecimento do Império (...). Ele deixou a Prússia intocada - ou seja, o Rei e a aristocracia militar matinham toda a autoridade - e ele criou um edifício constitucional imperial de onde a Prússia comandava o Império, e não o Império à Prússia”71. No Império, onde a Prússia ocupava esse papel decisivo, havia ainda um espaço claro e definido para as Forças Armadas. De acordo com E. J. Gumbel:

\footnotetext{
${ }^{69}$ ROSENBERG, Arthur, Op. cit., 1964, p. 1, trad livre de "The Bismarckian Empire and the Prussian army formed an indissoluble entity. (...)Bismarck chose another path. He united the military aristocracy of Prussia with the german middle class, placed the Hohenzollerns at the head of the whole edifice and so gave the Empire its peculiar stamp".

${ }^{70}$ ELIAS, Norbert, Op. cit, 1997. p. 27.

${ }^{71}$ Idem, 1964, p. 4. trad livre de "At the establishment of the Empire (...). He left Prussia untouched that is to say, the King and the military aristocracy retained all authority - and he raised an Imperial constitutional edifice from which Prussia ruled the Empire, not the Empire Prussia”.
} 
"A origem feudal do Exército o coloca em um patamar moral mais alto do que qualquer outra instituição governamental. Essa origem identificava o Exército Imperial com o Estado, cujo chefe reclamava a graça divina. (...) Sob o imperador o Exército tinha sido uma ‘comunidade para si mesmo', um Estado virtual dentro do Estado, com um grande orçamento, grupos sociais bem definidos, e conexões bem estabelecidas com os círculos dos grandes industriais”72.

Da maneira em que fora arquitetado o sistema do Império, o parlamento tinha pouca relevância na vida política, suas atribuições não eram determinantes na administração publica do Império $^{73}$. O Chanceler deveria prestar contas para o Imperador, e não ao parlamento, dessa maneira ocorria uma centralização das decisões no poder executivo, que se espelhava também nos governos dos Länder. Segundo

\section{Rosenberg:}

“O Reichstag poderia debater publicamente todas as questões políticas. O exército e a política externa, entretanto, foram excluídos de sua esfera de influência. (...) Já em políticas internas, a influencia do Reichstag foi limitada pelos direitos especiais garantidos aos Estados individuais e pela falta de controle sobre as ações do governo"74.

Após a unificação Alemã em 1871, o chanceler Alemão, Otto von Bismarck iniciou uma política que visava seduzir a classe operária e esvaziar as críticas da SocialDemocracia: decretou a lei dos acidentes de trabalho, reconheceu os sindicatos e instituiu o sistema de previdência social. No final do século XIX, era possível verificar uma melhora significativa nas condições materiais e educacionais na Alemanha. O dado fundamental é que o analfabetismo fora eliminado.

\footnotetext{
${ }^{72}$ GUMBEL, E. J., "Disarmament and Clandestine Rearmament under the Weimar Republic” in MELMAN, Seymour, Op. cit, 1958. p. 203-219. tradução livre de "The feudal origin of the army put this institution on a higher moral level than any other government institution. It identified the imperial army with the state, whose chief, himself, claimed a specific divine grace. (...) Under the emperor the army had been a "community of its own," a virtual state within a state, with large budgets, tightly-knit social groups, and elaborate connections with industrial management circles."

${ }^{73}$ Ao contrário do que ocorria na Prússia antes da Unificação. A disputa entre o Rei Guilherme e a Dieta Prussiana, que se recusara a votar créditos para a modernização do Exército , foi o motivo pelo qual o Rei convidou Bismarck para o cargo de Chanceler da Prússia.

${ }^{74}$ ROSENBERG, Arthur, Op. cit., 1964, p. 6, trad livre de "The Reichstag, indeed, could debate publicly all political questions. The army and foreign policy, however, were excluded from its sphere of influence. (...) In domestic affairs the Reichstag found its influence circumscribed by the special rights assured to the individual States as well as by its own complete lack of control over the actions of the government”.
} 
Diante do sucesso da Unificação e das políticas sociais de Bismarck que, de acordo com Arthur Rosenberg, criavam um sustentáculo do Império baseado nas classes altas e na classe média, houve um enfraquecimento do poder de influencia dos movimentos revolucionários na Alemanha. O medo de uma insurreição, no entanto, permanecia vivo na aristocracia e em parte da burguesia alemã. Segundo Rosenberg, " $O$ poder militar colocado nas mãos do Imperador garantiam à classe media capitalista a melhor defesa contra os perigos de uma revolução proletária socialista"75. Além disso, a unificação territorial fez com que diversas organizações partidárias também se unificassem sob uma bandeira única alemã, aumentando significativamente sua força política.

Os símbolos de prestígio na sociedade alemã que se formava continuavam ligados diretamente à vida militar, à aristocracia Junker, espelhados nos êxitos do exército prussiano e na figura de Otto von Bismarck. Conforme Eksteins:

\begin{abstract}
“A germanicidade era necessariamente mais uma questão de associação espiritual que de delineamento geográfico ou mesmo racial. Ao invés de enfraquecer esta internalização da vida, esta qualidade mitopoéica, Bismarck a acentuou. Bismarck 'prussianizou' a Alemanha e ao mesmo tempo transformou-a de realidade de uma expressão geográfica, em lenda"76.
\end{abstract}

O exército se constituiu como o mantenedor do código de honra que regulava um princípio de conduta humana preponderante após a Unificação Alemã. O sucesso da Unificação, inclusive com uma vitória expressiva contra o então poderoso Império Austro-Húngaro, levou o Estado Maior da Prússia ao predomínio na ocupação das altas patentes nas Forças Armadas do Império Alemão, embora houvesse também oficiais

\footnotetext{
${ }^{75}$ Idem, 1964, p. 7, trad livre de "The military power placed in the hands of the Emperor afforded the capitalist middle class the best defense against danger of a proletarian socialist revolution”.

${ }^{76}$ EKSTEINS, Modris, Op. cit., 1991. p. 95.
} 
vindos de outros Länder. Para as classes médias, a burguesia e outros estratos sociais, estavam reservadas as baixas patentes.

Mas para essa elite aristocrática e militar que formava o Estado Maior da Prússia, cujo êxito acompanhou um crescente após a "humilhação de Olmütz", em 1850, quando a Prússia teve de abandonar a União de Erfurt e aceitar a Confederação Germânica sob influencia Austro-Húngara. A partir de então, o Estado Maior prussiano galgou a posição de mais poderoso Estado Maior da Europa Continental, e cuja organização extrapolava as três armas, e controlava a vida social e política do Estado da Prússia, o fenômeno da Guerra estava ligado a sua própria existência, era um fato social revestido de 'normalidade', a guerra era o alicerce da vida social. Nas palavras de de Eksteins: "Em outras palavras, considerada como o alicerce da cultura [Kultur] ou como um patamar para um nível mas elevado de criatividade e espírito, a guerra era parte essencial da imagem e do amor-próprio de uma nação"77.

Já para os estratos sociais historicamente alijados do comando militar, o desejo de fazer parte da mesma casta que os oficiais aristocratas, cuja imagem tornou-se o símbolo máximo de prestígio no Império, após a bem sucedida Unificação, fazia com que os jovens burgueses e das classes médias que ingressavam no exército quisessem demonstrar seu valor através de uma interiorização forçada e imediata dos códigos de honra da aristocracia, altamente hierarquizados. Esses jovens viam na Guerra a experiência epifânica, a chance de se igualar em grandeza aos heróis da tradição guerreira germânica. Conforme explica Norbert Elias:

"para esses jovens oficiais de classe média, que a interiorização e as nuanças do código era algo diferente da dos nobres de altas patentes. (...) Isso significa que eles viram a guerra não do mesmo modo que a nobreza guerreira viu, simplesmente como um fato social, como parte do destino humano especialmente para soldados, mas pelo contrário, consideravam-na como algo imperativo e desejável, um ideal

\footnotetext{
${ }^{77}$ Idem, 1991, p. 124.
} 
do comportamento viril, pelo que sua violência e brutalidade eram vistas com grandeza e significação. Essa diferença desempenhou um papel não insignificante nas lutas internas pelo poder na República de Weimar"78.

O Exército estava incorporado como símbolo da construção nacional alemã levada a cabo pela nobreza prussiana, ainda que houvesse divisões culturais e conflitos políticos dentro da Alemanha. Nesse sentido, a guerra seria a celebração máxima da unidade do povo, pois era nesse momento que o heroísmo e a virilidade do alemão se expressariam de maneira plena. A força seria a expressão do prestígio; as fraquezas do homem, a fraternidade iluminista, a piedade cristã eram expressões de debilidade que significavam derrota e fracasso. Nesse sentido, escreve Nietzsche:

“O que é bom? - tudo o que eleva no homem o sentimento de potência, a vontade de potência, a própria potência.

O que é mau? - Tudo o que nasce da fraqueza.

O que é a felicidade? - O sentimento de que a potência cresce - de que uma resistência foi superada.

Não a satisfação, porem mais potência; não a paz acima de tudo, mas a guerra; não a virtude, mas a habilidade (virtude no estilo da Renascença, virtú, virtude isenta de juízo moral).

Quanto aos débeis, aos imprestáveis, que pereçam; primeiro princípio de nossa caridade. E que se os ajude, enfim, a perecer.

O que é mais pernicioso que qualquer vício? - a compaixão ativa por todos os débeis e todos os imprestáveis; o cristianismo..."

Embora, o escrito de Nietzsche seja bastante radical, pairava no mito nacional que se construía na Alemanha unificada, a idéia de que o Völk (povo) alemão deveria expressar sua unidade e sua identidade nacional através daquilo que Nietzsche chama de vontade de potência, ou seja, da expressão do código de honra guerreiro e do profundo respeito à hierarquia e a disciplina. Esse código se expressava em cada momento da vida social no Império alemão, e não apenas na vida militar. Foi através desse modelo

\footnotetext{
${ }^{78}$ ELIAS, Norbert, Op cit, 1997, p. 193-194.

${ }^{79}$ NIETZSCHE, Friedrich, The Antichrist, Nova York, Viking, 1954. p. 570, tradução da citação por Álvaro Cabral, em ELIAS, Norbert, Op. cit, 1997. p. 113.
} 
de disciplina e hierarquia que a Alemanha Imperial promoveu um intenso desenvolvimento econômico. Como aponta Eksteins:

\begin{abstract}
"Em um período pouco maior que o de uma geração, menor que o de uma vida prolongada, a Alemanha tinha deixado de ser um agrupamento geográfico, com elos econômicos limitados entre suas partes, para se tornar a mais formidável potência industrial da Europa, sem falar em seu poderio militar”80.
\end{abstract}

Esse processo de desenvolvimento iniciou-se em um período de crise na Europa, com a quebra da Bolsa de Valores de Viena em 1873. No período que se estende até 1895, apesar da situação econômica desfavorável, a Alemanha conseguiu empreender uma melhoria na sua infra-estrutura, portos, estradas de ferro e indústria naval.

A atividade econômica nos setores privados, no entanto, se encontrava enfraquecida nesse período de crise, com um desemprego alto e com os preços em média $40 \%$ mais baixos ${ }^{81}$. Mas o desenvolvimento da infra-estrutura no período, aliado com o progresso tecnológico ocorrido nos processos industriais, fizeram com que a Alemanha, a partir de 1895 experimentasse um ciclo virtuoso de crescimento econômico e melhora na qualidade de vida da população. Impulsionado pela industria naval e pela produção de carvão e aço, o crescimento alemão no período foi duas vezes maior que o inglês. A produção de carvão passou de 89 milhões de toneladas em 1890 para 227 milhões de toneladas em 1914; já a produção de aço, em 1914, superava em 17,6 milhões de toneladas a produção somada de Inglaterra, Rússia e França. Além disso, outras novas industrias experimentavam um desenvolvimento significativo, como era o caso da elétrica AEG, da Bayern, da Hoescht, da Siemens e do império de Krupp $^{82}$. Nas palavras de Beaud:

\footnotetext{
${ }^{80}$ EKSTEINS, p. 97.

${ }^{81}$ TOUGAN-BARANOWSKY, Michel. L'Evolution historique du socialisme moderne, Paris, Riviere, 1913. p. 139,

${ }^{82}$ KENNEDY, Paul, Ascensão e queda das grandes potências: Transformações econômicas e conflito militar de 1500 a 2000, Rio de Janeiro, Campus, 1989, p. 207-209.
} 
"Na Alemanha, é o Império industrial constituído por Krupp: 7 mil assalariados em 1873, 78 mil em 1913; é a indústria elétrica AEG que, graças a um fulgurante processo de concentração, controla em 1911, de 175 a 200 sociedades; emprega mais de 60 mil assalariados; coopera desde 1908 com outro grupo alemão Siemens e divide mercados mundiais com o grupo americano General Eletric”83.

O surgimento de uma Alemanha forte e desenvolvida no meio da Europa, cujas pretensões de seu imperador Imperador Guilherme II passavam pelo estabelecimento de uma Weltpolitik, para que a Alemanha participasse de maneira melhor da divisão das colônias imperiais e pela construção de uma esquadra que fizesse frente à inglesa, levou a um desenvolvimento das tensões entre as potencias européias. Essas crescentes tensões entre as potências européias no início do século XX colocaram a Guerra na ordem do dia. E isso ascendeu os ímpetos nacionalistas e guerreiros nas nações européias. Em especial na Alemanha, onde a guerra era vista como um remédio contra o tédio do mundo, conforme relata Peter Gay:

\begin{abstract}
“A Guerra oferecia 'purificação, libertação e uma enorme esperança'; 'inflamava o coração dos poetas' com uma sensação de alívio que 'o mundão de paz havia feito desmoronar', um mundo no qual 'estava-se cansado, tão tremendamente cansado'. Somente a 'vitória a qualquer preço' poderia dar um significado à vida; os alemães haviam finalmente se reunido com um Völk, unicamente os alemães eram 'verdadeiros, autênticos, machos e objetivos', uma terra de heróis enfrentando adversários carregados de 'covardia, baixeza e falsidade', palavras bombásticas como Völk, Reich e Geist ganhavam agora novo significado nessa grande cruzada pela Kultur. (...) são essas as expressões de Thomas Mann e Friedrich Gundolf",84.
\end{abstract}

Esse tédio, segundo aqueles que estavam em torno do Exército, a nobreza militar ou ainda, a classe média que procurava interiorizar o código de honra dos estratos guerreiros, advinha de dois fatores, de uma lado a hora de demonstrar a coragem, a disciplina e a honra dessa nova nação, desse novo Völk; de outro lado, havia a sensação de que o longo período de paz e os avanços tecnológicos, científicos e, principalmente,

\footnotetext{
${ }^{83}$ BEAUD, Michel, Op. cit, 1989, p. 225.

${ }^{84}$ GAY, Peter, Op cit. 1978, p. $24 / 5$.
} 
a força crescente das idéias iluministas, cuja medida se dava pelos 34\% dos votos para o Reichstag obtidos pelo SPD em 1912, causavam uma degeneração da Kültur e da vida alemãs. As idéias que se espalhavam, de positivismo, liberalismo, marxismo, ciência e razão, estariam com seus dias contados com a chegada da Guerra, segundo Jeffrey Herf:

\begin{abstract}
“A Primeira Guerra Mundial foi uma fonte de esperança, para aqueles pessimistas culturais alemães que acreditavam na possibilidade de uma reversão radical do processo de degeneração que sentiam estar ameaçando o corpo e a alma da nação. A mensagem deles não era fundamentalmente que o mundo fora abandonado por Deus, mas que podia ser salvo e a deterioração sustada e revertida”,85.
\end{abstract}

Mais do que isso, a Guerra era vista com o momento de estabelecer um novo equilíbrio no continente, um equilíbrio que levasse em conta o papel do Império Alemão no mundo. O sentimento de ir a Guerra perpassava a população: a ida a guerra era o triunfo do Völk reunido sob uma bandeira única alemã pela primeira vez em séculos. Em um discurso do balcão do Palácio Real, em 1 de agosto de 1914, no dia seguinte a declaração de Guerra pela Alemanha, o Kaiser Guilherme II proferiu as seguintes palavras:

"Eu agradeço a vocês do fundo do meu coração pela expressão de estima e lealdade. Quando se chega a guerra, todas as divisões cessam e somos todos um único povo. Um ou outro partido me atacou no período de paz, mas agora eu os perdôo de coração. Se nosso vizinhos não nos derem paz, então eu espero e desejo que a nossa boa Espada Alemã saíra vitoriosa dessa guerra!”86.

Esse clima que perpassava a população, de euforia e confiança, tomou rapidamente conta da administração pública e dos políticos. Berlim permanecia

\footnotetext{
${ }^{85}$ HERF, Jeffrey. O Modernismo Reacionário, São Paulo, Ensaio, 1993, p. 31.

${ }^{86}$ Citado por EKSTEIN, Modris, Op. cit, 1991, p. 88, e reproduzido na íntegra em http://wwi.lib.byu.edu/index.php/Wilhelm_II\%27s_War_Speeches, consultado em 07/07/2009, às 23h00. trad livre de "I thank you from the bottom of my heart for the expression of your loyalty and your esteem. When it comes to war, all parties cease and we are all brothers. One or another party has attacked me in peacetime, but now I forgive them wholeheartedly. If our neighbors do not give us peace, then we hope and wish that our good German sword will come victorious out of this war !”. A expressão "um unico povo foi traduzida como "we are all brothers", mas em alemão os registros apontam para "ein völk".
} 
eufórica, as pessoas marchavam junto aos soldados - alguns demonstravam grande felicidade; a maioria cantava hinos germânicos e gritava palavras de confiança e louvor à nação; apenas alguns poucos se opunham a Guerra. Dentre estes últimos, a ala esquerda do SPD, que na votação dos créditos para a Guerra romperia com o partido, e alguns intelectuais e artistas, para quem a guerra e a destruição era apenas um momento absolutamente anti-humano. Segundo Eksteins:

"Todos os que tem poder de decisão defrontam-se diretamente coma maciça efusão de entusiasmo do povo de Berlim. Nenhum deles jamais viu tais manifestações antes. Nenhum deles pode ignorar o ânimo popular. (...) Nenhum líder político poderia ter resistido às pressões populares a favor de uma ação decisiva",87.

Esse estado de ânimos pode ser ricamente captado na coleção de excertos reunidos por Modris Ekstein em A Sagração da Primavera. Frans Kafka anotou em seu diário no dia 2 de agosto de 1914 “A Alemanha declarou guerra à Rússia - natação à tarde״88, já um um repórter do Vossische Zeitung dava conta do clima de união que tomara todo o povo em torno da ida à Guerra: “Os alemães e os austríacos, o estudante e o soldado, o comerciante e o trabalhador, todos se sentem unidos nessa hora extremamente grave”89. De acordo com a descrição, os ânimos estavam a flor da pele, havia chegado o momento máximo desse Völk unido, a expressão daquilo que Nietzsche chamou de Vontade de potência. Um Repórter do Täglich Rundschau escreveu:

“[Começou!] Esta é a frase de todos neste momento. Ela fere fundo. E de repente, antes que se tenha consciência do que acontece, formou-se uma multidão. Ninguém conhece ninguém. Mas todos são dominados por uma emoção sincera: Guerra, guerra e um sentimento de camaradagem,"90.

\footnotetext{
${ }^{87}$ EKSTEIN, Modris, Op. cit, 1991, p. 88.

88 apud Idem, 1991, p. 81.

89 apud Ibidem, 1991, p. 84.

90 apud Ibidem, 1991, p. 82.
} 
A proximidade da experiência da Guerra conduzia aquela população, cuja expressão do código de honra guerreiro era o ponto máximo da vida, à experiência inefável, um êxtase social arrebatava a todos, em um momento de confiança e alegria. Mais do que isso, a consciência coletiva em torno do desse código guerreiro levava a guerra a um patamar que extrapolava qualquer relação objetiva: era a vitoria da subjetividade anti-racionalista, anti-iluminista e anti-humanista; a vitória do romantismo nacionalista que havia sido cultivado pelos estratos da nobreza militar e que agora se mostrava disseminado por quase toda a população, convertendo a guerra em uma experiência que Eksteins descreve como estética:

\begin{abstract}
"No começo de agosto os alemães deliciam-se com o que lhes parece ser a síntese genuína de passado e futuro, a eternidade encarnada no momento e a resolução de todas as discórdias internas - partido versus partido, classe contra classe, seita contra seita, a igreja em conflito com o Estado. A vida alcançou uma transcendência. Estetizou-se. A vida transformou-se numa Gesamkunstwerk wagneriana, na qual as preocupações materiais e todas as questões mundanas são ultrapassadas por uma força de vida espiritual”’1.
\end{abstract}

Após o fim do conflito, a abdicação de Guilherme II e o advento da República, a correlação de forças e de papéis na vida política da República mudou. Conforme nota Rosenberg, "O Fim veio quando a casta militar prussiana entrou em colapso em 1918 e a classe média tomou o governo"

Na República de Weimar, esse sentimento em relação a Guerra se manteve vivo no indivíduo alemão, a Guerra era "o supremo teste do espírito e, como tal, um teste de vitalidade, cultura e vida"93. Mesmo após a derrota e o Tratado de Versalhes, o exército não pode ser totamente excluído da vida e do ethos do alemão. Em primeiro lugar porque era necessária a existência de uma burocracia para a nova República, e essa

\footnotetext{
${ }^{91}$ Ibidem, 1991, p. 89-90. Gesamkunstwerk significa Obra de Arte Total (trad livre).

${ }^{92}$ ROSENBERG, Arthur, Op. cit., 1964, p. 1, trad livre de "The end came when the Prussian military caste collapsed in 1918 and the middle class took over the government”.

${ }^{93}$ EKSTEIN, Modris, Op. cit, 1991, p. 124.
} 
burocracia não poderia ser forjada do zero, e carecia do apoio das burocracias

provenientes do Império. No caso do exército, todos os indivíduos em idade adulta já

haviam passado pelo exército, absorvido seu treinamento e, com isso, tido contato com

os códigos morais do exército - e como o Exército foi o sustentáculo da nova

Republica, no pacto arquitetado por Groener e Ebert, o Exército manteve sua

organização interna e sua estrutura de comando. A esse respeito, diz Gumbel:

\begin{abstract}
"O Exército, cujas altas patentes provinham da aristocracia, eram uma importante força política. O Imperador era, antes de tudo o Comandante em chefe do Exército. Dessa maneira, o Exército tinha forte identificação com o Império. Sua continuação sob comando de oficiais treinados pela monarquia era uma contradição da República. O Exército era um corpo estranho para objetivos socialistas, e liberais, da República. Prova disso é o fato de que o Exército nunca aceitou as cores pretovermelho-ouro da República, retiradas da Revolução de 1848. Toda a história de Weimar é caracterizada pelo antagonismo entre o Exército e os poderes civis" ${ }^{34}$.
\end{abstract}

Após o fim da Guerra e a desmobilização de parte dos exércitos, surgiram no

interior da República uma miríade de grupos paramilitares, dentre os quais o Freikorps ${ }^{95}$, que promoviam através da violência a disciplina contra os antipatriotas:

"perseguiam um duplo objetivo: dentro do Estado, o fim do sistema multipartidário e a restauração de relações claras, hierárquicas e formalizadas de domínio e subordinação, tal como existiram durante o reinado do Kaiser, o Kaiserzeit; e externamente, a recuperação da posição da Alemanha como grande potência, com ou sem guerra"

\footnotetext{
${ }^{94}$ GUMBEL, E. J., "Disarmament and Clandestine Rearmament under the Weimar Republic" in MELMAN, Seymour, Op. cit, 1958. p. 203-219. tradução livre de "The army, where the higher echelons were chosen from the aristocracy, was a strong political force. The emperor was, first of all, the Chief of the Army. Thus, the army had been identified with the empire. Its very continuation under monarchistminded officers was a contradiction to the Republic. The army was a body foreign to the socialist, and later liberal, aims of the Republic. As a sign, the army never accepted the black-red-gold colors of the Republic, taken from the Revolution of 1848. The whole history of Weimar is characterized by the antagonism of the army and civilian powers".

${ }^{95}$ A designação Freikorps surgiu durante o reinado de Frederico II na Prussa, no período da Guerra dos Sete Anos (1756-1763), e foi retomado por grupos paramilitares nas Guerras Napoleônicas e depois na República de Weimar.

${ }^{96}$ ELIAS, Norbert, Op cit, 1997, p. 195.
} 
Essa disciplina significava mais do que o respeito às leis; pelo contrário, significava a defesa do código de honra dos estratos guerreiros contra código moral das classes médias representado pela democracia parlamentar instaurada pela constituição de Weimar. Os signos de igualdade e livre-iniciativa estabelecidos com a democracia, para esses grupos, representavam a derrota e o fracasso da Alemanha; em última instância, eram anti-alemães.

Nesses grupos a expressão da vontade de potência produzia a glorificação da violência física e do combate. Ainda que formalmente desligados das Forças Armadas, esses grupos exibiam signos militares, marchavam pelas ruas portando estandartes e vestidos a caráter. Nas palavras de Herf, esse grupos recriavam na república a “comunidade masculina das trincheiras”, ou o remédio militar contra a degeneração da vida alemã, “Em Weimar, a comunidade masculina das trincheiras, recriada nos grupos paramilitares tais como os Freikorps, dava à tradição reacionária sua utopia concreta, sua visão de boa sociedade e seu tesouro perdido"97.

Logo nos primeiros dias da República, com a tentativa de revolução em Berlim por Rosa Louxembourg e Karl Liebknetch, e na Bavária por Kurt Eisner, os Freikorps estiveram a frente da repressão às sublevações revolucionárias, massacrando seus líderes de maneira brutal e contando com o apoio do então ministro social democrata Gustav Noske. De acordo com Peter Gay: “O Social-Democrata Noske, encarregado de restaurar a ordem, foi ajudado assaz dubiamente pelo fanático Freikorps organizações paramilitares formadas às pressas, de ex-oficiais, desempregados à deriva e jovens aventureiros ansiosos por matar ${ }^{\prime 98}$.

Os Freikorps chegaram a somar 63 organizações paramilitares espalhadas por toda a Alemanha. Os mais importantes foram: A Divisão Voluntária de Cavalaria de

\footnotetext{
${ }^{97}$ HERF, Jeffrey. Op. cit., 1993, p. 37.

${ }^{98}$ GAY, Peter, Op. cit., 1978, p. 169.
} 
Guarda, liderada pelo Capitão Pabst e responsável pelo assassinato de Rosa Louxembourg e Karl Liebknecht; o Freikorps Maercker, o Freikorps Rossbach, a Segunda Brigada Naval - que apesar do nome não tinha vínculos com o Estado -, que participou do putsch Kapp e depois se converteu na Organização Cônsul, responsável por diversos assassinatos políticos; e a Divisão de Ferro.

Em 1920 os Freikorps foram oficialmente desmobilizados por Noske, após o líder da Divisão Voluntária de Cavalaria de Guarda, o Capitão Pabst, ter ameaçado Noske de morte. Mas os Freikorps se mantiveram na ativa enquanto violentos agitadores: participaram do putsch Kapp no mesmo ano, e não apoiaram a tentativa de golpe empreendida por Hitler e Ludendorff em 1924. Mesmo assim, a história destes grupos os aproximou paulatinamente de Hitler e do Partido Nacional-Socialista. Muitos dos membros que ingressaram no Partido Nacional-Socialista eram ex-integrantes dos Freikorps. Dentre os mais importantes, o chefe das SA até 1934, Ernst Röhm e o chefe das SS, Heinrich Himmler.

Ambas, SA e SS, funcionarão de maneira muito parecida com os Freikorps, e isso se expressará de sobremaneira nos violentos combates que estas organizações travarão contra os Comunistas e os Socialistas nos derradeiros anos da República. Estas organizações, que eram parte do Partido Nacional-Socialista, incorporaram esse ímpeto destrutivo de glorificação da violência. Com o aumento dos confrontos envolvendo este tipo de organização paramilitar, a autoridade da República foi sendo minada, e as disputas políticas se exacerbaram.

Tamanho era o significado da ligação entre Freikorps e os Nacional-Socialistas, que em 9 de novembro de 1933, em uma grande cerimônia, os antigos líderes de varias facções Freikorps, entregaram sua bandeira para Hitler, que proferiu as seguintes palavras: 
“As organizações que defendiam interesses de classes, naturalmente resistiram à sua dissolução; mas não se pode deixar que um povo se arruíne porque tais organizações desejam existir. Porque o povo não vive para teorias, para programas ou para organizações, mas todos estes têm que servir a vida da nação",99.

Norbert Elias defende que essa glorificação da violência esteve presente durante os anos da República, não apenas nestas organizações paramilitares, mas no imaginário alemão: o combate era o símbolo da virilidade e o caminho mais curto para a expressão da potência. Elias analisa a literatura pró-guerra de Ernst Jünger como expressão desse ideal de guerra no imaginário alemão, Elias cita Jünger:

\begin{abstract}
“A descrição de Jünger dá-nos uma idéia disso. Ele mostra como, através do encorajamento mútuo, do consumo de álcool e da auto-estimulação para gerar um ânimo de extrema fúria, as pessoas buscaram superar coletivamente as barreiras íntimas e satisfazer a obrigação social de ser corajoso:

'(...) O desejo incontrolável de matar me impelia para diante. A raiva fazia brotar lágrimas amargas de meus olhos.

A vontade assustadora de destruição que pairava sobre o campo de batalha comprimia-se em nossos cérebros e envolvia-nos numa névoa rubra. Gritávamos frases quebradas uns para os outros, soluçantes, gaguejantes, e, um espectador desavisado que nos observasse poderia acreditar, talvez, que éramos impelidos por um excesso de felicidade ${ }^{\text {"100 }}$.
\end{abstract}

Todos esses elementos ligados à glorificação da guerra e da violência como símbolo da nacionalidade alemã, da coesão do povo em torno de um código de honra guerreiro estavam presentes na República, mas não como um elemento que conferisse autoridade ao regime republicano e à Constituição de Weimar, pelo contrário, KPD e SPD negavam historicamente esses preceitos da nobreza militar; o Zentrum, por sua vez, tinha seu apoio nas classes médias que estavam entre negar os códigos da Nobreza e aceitá-los como um elemento externo que lhes era imposto. Os grupos que tinham seu ethos ligado à ao código de honra guerreiro e ao Império tinham apoiado a Guerra em 1914, e viam a República como símbolo da derrota externa “na luta pela supremacia na

\footnotetext{
${ }^{99}$ HITLER, Adolf, Minha Nova Ordem, Porto Alegre, Meridiano, 1943, p. 175-176.

${ }^{100}$ ELIAS, Norbert, Op cit, 1997, p. 192-193.
} 
Europa”, e da derrota interna, "na luta pela supremacia dentro da Alemanha"101. Esses grupos, segundo Elias:

"incluíam a aristocracia alemã com sua extensão no oficialato das forças armadas, o alto funcionalismo público na administração e o judiciário da classe média alta, alem de uma vasta proporção de industriais, comerciantes em grande escala e banqueiros alemães" ${ }^{\text {,102 }}$.

Para esse grupos, o lema “Ein Völk, ein Reich, ein Führer!” que os Nacional Socialistas repetiam à exaustão, combinava-se à imagem da disciplina militar com que os partidários dos Nacional-Socialistas desfilavam e saudavam Hitler. Essa imagem contrapunha-se a tudo aquilo que a República significou para esses antigos partidários do Kaiser: a desordem publica, fragmentação social e política, inflação e a humilhação de Versalhes. Mas, à altura dos acontecimentos, a posição do Kaiser, e de retomada do Império enquanto instituição parecia uma coisa pouco provável. Esse ímpeto antirepublicano se converteu cada vez mais, em especial após o período de grande instabilidade entre 1918 e 1923, em uma busca por um modelo anti-liberal novo, que desse conta do verdadeiro espírito alemão de maneira adequada, nas palavras do poeta Hugo von Hoffmannstall (citado por Herf em nota no trecho a seguir), buscavam "não a liberdade, mas o vínculo de comunidade”. Segundo Herf:

\footnotetext{
“Opunham-se veementemente à República de Weimar, identificando-a com a guerra perdida, Versalhes, a inflação de 1923, os judeus, a cultura cosmopolita de massas e o liberalismo político. Almejavam um novo reich de enorme força e unidade, rejeitavam a opinião de que a ação política devesse guiar-se por critérios racionais e idealizavam a violência pela violência. Denunciavam o que acreditavam fosse o fastio e a complacência da vida burguesa e procuravam renovação em uma 'barbárie' revigorante", 103 .
}

\footnotetext{
${ }^{101}$ Idem, 1997, p. 194-195.

102 Ibidem, 1997, p. 194-195.

${ }^{103}$ HERF, Jeffrey. Op. cit., 1993, p. 34.
} 
E Hitler, converteu esse ímpeto guerreiro, tão presente nesses elementos antirepublicanos - e em especial nos freikorps -, que potencialmente destruiria o Estado de dentro para fora, em um ímpeto transformador, que aliava o ethos e a tradição alemã a uma proposta política nova e disciplinadora. Elias observa com clareza que esse ímpeto, que resistiu por toda a o período da República, delcaradamente anti-republicano, já não tinha nada que ver com o Império Guilhermino, era um ímpeto destrutivo que encontrou sua face construtiva, por assim dizer, no conjunto de propostas políticas e principalmente - ideológicas do Hitler:

\begin{abstract}
"A violência do movimento nacional-socialista, com a ajuda de associações de defesa privadamente organizadas, tinha causado a quase completa dissolução do monopólio de força - sem o qual o Estado, a longo prazo, não pode funcionar - e destruiu a República de Weimar de dentro para fora; (...). O plano da juventude nacionalista desses dias, (...), era um tanto vago e negativamente definido. Ernst Jünger escreveu que nada tinha a ver com monarquia, conservadorismo, reação burguesa ou com o patriotismo do período Guilhermino. Através da tomada do poder por Hitler, esse propósito negativo recebeu um rosto positivo. Assim, 30 de junho de 1934 foi o símbolo típico, (...), do divisor de águas no desenvolvimento de um movimento revolucionário radical, que obteve êxitos e cujos adeptos se converteram, então, de destruidores do Estado em representantes do Estado."104
\end{abstract}

\title{
3.1 A arte na contraposição entre a vontade de potência e o Iluminismo
}

\begin{abstract}
"Por isso, ironicamente, enquanto a consolidação ocorria em um nível - na população, na indústria e na estrutura do Estado -, a desintegração caracterizava os campos social, político e, talvez de forma muito significativa, o psicológico. O resultado foi uma preocupação com a administração da vida, com a técnica, a ponto de esta se tornar um valor e um objetivo estético, e não apenas um meio para atingir um fim”105.

"O Expressionismo, que surgiu na virada do século XIX para o século XX, tem suas raízes, basicamente, na Escandinávia, na Alemanha e na França - e não pode ser classificado como um estilo uniforme -, trata-se de uma reação artística à situação instável do clima social, em todas as regiões européias. Culturalmente, essa época oscilava entre presságios apocalípticos e uma nova consciência do indivíduo, politicamente entre as estruturas desgastadas da tradição monárquica, na Alemanha, e das idéias radicais de uma sociedade revoltada, que pretendia apoderar-se do poder. Não é de admirar que na luta entre essas energias espirituais
\end{abstract}

\footnotetext{
${ }^{104}$ Ibidem, 1997, p. 208.

${ }^{105}$ EKSTEINS, Modris, Op. cit., 1991, p. 99.
} 
antagônicas tenha surgido um imenso campo de tensão, contendo, ao mesmo tempo, a representação apavorante da grande cidade que gera depravação, do poder de destruição da guerra e do sonho eufórico de um homem "novo" com uma visão paradisíaca de reaproximação entre o homem e a natureza”106

Já no último quartel do século XIX podia-se sentir nos meios culturais da Alemanha uma oposição entre a pintura, a literatura e a música oriundas do Romantismo e as novas experimentações, sob influencia de movimentos pré-modernos no resto da Europa, como o impressionismo na Pintura. Da mesma maneira em que código de honra dos estratos guerreiros se contrapunha ao código moral das classes médias havia uma contraposição clara entre a arte romântica, que se convertera definitivamente na linguagem artística da Monarquia alemã, do II Reich e cuja expressão máxima é a obra musical neo-romântica ${ }^{107}$ de Wagner; e as novas experimentações apareciam cada vez mais como uma arte desordenadora, cosmopolita, crítica e revolucionária. Sobre essa nova arte, escreveu um Príncipe Bávaro em 1893:

\begin{abstract}
"Um trabalho monstruoso e infame, de um realismo social-democrático e ao mesmo tempo cheio de misticismo doentio e sentimental, desorientador, de um modo geral abominável. Depois fomos ao Borchard, para tentar readquirir uma mentalidade humana, com champagne e caviar, ${ }^{\text {,108 }}$.
\end{abstract}

Estava claro, desde a Unificação, em 1871, que a arte trilhava caminhos distintos nos estratos da aristocracia que comandavam o Império Alemão e na burguesia e nas classes médias alijadas dos centros de decisão política do Império. Mas, ainda que trilhando caminhos distintos em seu desenvolvimento, ambos os grupos tinham preocupações em comum. A definição do que era o homem alemão, qual deveria ser o papel da materialidade e qual o papel do espírito na vida deste homem, o que

\footnotetext{
106 THOMAS, Karin, Bis heute: Stilgesschichte der Bildenden Kunst im 20 Jahrhundert, Köln, Dumont Buchverlag, 1944. p. 73.

${ }^{107}$ A própria característica do movimento chamado neo-romântico, já é um evidente exemplo do prolongamento anacrônico, se comparado com outros países da Europa, do programa artístico do romantismo na Alemanha.

${ }^{108}$ GAY, Peter. p.17.
} 
representava o homem primitivo eram temas comuns dentre esses grupos. Nas palavras de Eksteins, “o ethos essencial da Alemanha antes de 1914 subentendia uma busca de novas formas concebidas não em termos de leis e finitude, mas em termos de símbolo, metáfora e mito"109. Já o crítico Wilhelm Worringer, em 1908, cunhou a expressão "Ansiedade Metafísica" 110 para definir aquilo que marcaria a arte da virada do século XIX para o XX na Alemanha. Ou, nas palavras do artista Wassily Kandinsky, "hoje a ansiedade metafísica é a condição geral da humanidade, não existem mais fronteiras como na Idade Média, o que distingue um povo do outro é apenas o grau de consciência dessa ansiedade, de cada indivíduo e de cada povo"111.

Mas era nesses grupos alijados do poder político que a arte encontra sua variante mais violenta e radical - transformadora. Enquanto a Monarquia alemã celebrava o Romantismo, de marcado Naturalismo acadêmico ${ }^{112}$, como a arte da Alemanha unificada, como a expressão estética ser alemão; nesses grupos havia uma busca por algo novo, algo cosmopolita, que nada tinha que ver, esteticamente, com o Naturalismo acadêmico.

\begin{abstract}
"O elemento mais importante dessa revolta emocional dos intelectuais e artistas alemães foi sua oposição às autoridades, que se tornou cada vez mais perceptível na Alemanha, ao longo do século XIX. (...) As divergências culturais são mais profundas quando existem tensões políticas entre exigências autoritárias e movimentos de reforma liberal. No lugar do Romantismo idealista de Böcklin, Feuerbach, Klinger e Von Marées, surgem expressões mais fortes de artistas como Hodler e Munch e o realismo social de Käthe Kollwitz, que retratam a miséria humana" ${ }^{\prime 13}$.
\end{abstract}

Esses grupos que procuravam romper com a arte acadêmica celebrada pelo Império, procuravam fora da Alemanha elementos transgressores para compor seu

\footnotetext{
${ }^{109}$ EKSTEINS, Modris, Op. cit., 1991, p. 113

110 apud GUINSBURG, Jaco, O Expressionismo, São Paulo, Perspectiva, 2002. p. 392.

111 apud GUINSBURG, Jaco, Op. cit., 2002. p. 392.

112 Era característica marcante do Romantismo nas artes plásticas o Naturalismo acadêmico, que celebrava a verossimilhança na representação da figura humana e das paisagens, obtida através do uso de um processo técnico acadêmico, fosse na pintura a óleo, nas aquarelas ou na escultura em barro e bronze. ${ }^{113}$ Idem, 2002, p. 390.
} 
léxico. Algo que rejeitasse a representação naturalista e material, que expressasse seu estado de espírito em detrimento da realidade material, a obra seria fruto da viagem interna do artista e de sua percepção de mundo. A liberdade representativa que eles procuravam era análoga a que Vincent Van Gogh - ele mesmo uma das principais influencias dos pintores alemães no início do século XX - descreve:

\begin{abstract}
“Ao invés de representar o que vejo pela frente, uso a cor de modo exagerado para me expressar com mais força. (...) Quando quero pintar o retrato de um amigo artista, loiro, sonhador e quero expressar todo amor que sinto por ele, farei o seu retrato o mais fiel possível. Mas não para por aí. Para terminá-lo, serei um colorista arbitrário, exagero o loiro do cabelo chegando a tonalidades de laranja, cromo ou cítrico, atrás da cabeça, em vez do muro, pinto o infinito, o azul mais forte que consigo. Assim a cabeça loira, luminosa, contrasta com o azul puro dando um efeito místico, como a estrela na noite profunda" ${ }^{\text {114 }}$.
\end{abstract}

Essa liberdade estes artistas alemães encontraram no Impressionismo, que despontara na França na segunda metade do século XIX, rompendo não só com a tradição acadêmica francesa, mas também com os salões oficiais franceses, onde uma única tendência era celebrada pelos críticos oficiais do Estado. Os pintores impressionistas, capitaneados por Manet, haviam criado os salões dos independentes e com isso, inaugurado o livre mercado para os artistas plásticos franceses. Essa ruptura foi fundamental para que os novos pintores pudessem se afirmar em Paris com liberdade para experimentar e $\operatorname{criar}^{115}$.

A influência do Impressionismo deu o tom ao movimento de libertação do romantismo nas artes plásticas. A descoberta da luz e da cor como linguagens de expressão fundamentais, da fuga da representação perfeita do tema retratado, e, principalmente, do movimento gestual do artista, trouxe uma nova luz ao desenvolvimento dos artistas alemães. A descoberta da obra de Paul Cézanne e, sobretudo, Paul Gauguin e Van Gogh influenciou em definitivo aqueles que se

\footnotetext{
114 apud Ibidem, 2002, p. 393.

${ }^{115}$ A esse respeito ver PEDROSA, Mário, Mundo, Homem, Arte em Crise, São Paulo, Perspectiva, 1975.
} 
aventuravam nas artes. Logo, no norte da Europa surgiu também o pintor Edvard Munch, cuja pintura ecoou pelas estepes germânicas. Sobre os Expressionistas alemães e sua influência do Impressionismo, diz Karin Thomas:

\begin{abstract}
"Possuem uma expressividade pictórica simples e direta, cujo vocabulário é formado de cores puras e fortes, superfícies grandes, pinceladas expressivas de forte tensão, e de uma deformação formal extremamente expressiva que, às vezes, chega perto da caricatura. Como os cubistas, os expressionistas recusam a arte sensual do Impressionismo, mas dele aproveitam os efeitos sensuais da luz e da cor, que permitem um conteúdo de forte expressividade e emotividade das cores"
\end{abstract}

Esses artistas, à procura de uma expressão própria distinta do desenvolvimento artístico francês, resgataram a gravura como forma não só de expressão artística, mas também de ativismo social. A gravura, cuja tradição na Alemanha remonta à obra de Rembrandt e Dührer, no século XVII. A descoberta da gravura significou, para todos aqueles artistas que buscavam uma arte nova, a possibilidade de divulgar sua obra através da reprodução técnica, em livros, revistas, jornais e cartazes. E além disso, a possibilidade de propagar a nova proposta estética dentre uma população cujo acesso as artes era negado devido às restrições financeiras - o número de operários na Alemanha saltou de 5,9 milhões em 1895 para 8,6 milhões em $1907^{117}$.

\begin{abstract}
"Por isso a prioridade da gravura, especialmente a xilogravura: é um método arcaico, artesanal e popular, arraigado na tradição figurativa alemã. Mais do que uma técnica, é um meio para comunicar a imagem não como mensagem do artista, mas como comunicação de homem para homem. As operações manuais se expressam na matéria com dificuldade, pela rigidez e angulosidade das linhas e marcas nas fibras da madeira - imprimi-se com um ato de força”118.
\end{abstract}

Havia, entretanto, nesses artistas alemães que se destacavam como a vanguarda da criação artística, uma percepção de mundo diferente daquela dos colegas artistas

\footnotetext{
116 THOMAS, Karin, Op. cit., 1944. p. 73.

${ }^{117}$ BEAUD, Michel, Op. cit, 1989, p. 206.

${ }^{118}$ ARGAN, Giulio Carlo, El arte moderno, Valencia, Fernando Torres, 1976, p. 287.
} 
franceses e latinos de modo geral. Enquanto os artistas latinos, herdeiros diretos do iluminismo, intérpretes objetividade usam da razão como ímpeto criador fundamental, os Expressionistas alemães tendem a sobrevalorizar o espírito das coisas em detrimento do racional, o subjetivo ao invés da objetividade, a intuição. O elemento primitivo, que aparecera nas obras de Gauguin pintadas no Taiti sob um enfoque antropológico, e nas Demoiselles d'Avignon de Picasso, como máscaras africanas que buscavam provocar o estranhamento do espectador, surge nas obras do Expressionismo alemão como a busca pelo indivíduo "puro", livre da racionalidade. O pintor Emil Nolde explica: "Homens primitivos vivem na natureza, integram-se nela, são parte de um todo. Às vezes, tenho a sensação de que são os únicos seres humanos reais que ainda restam, e que nós, por outro lado, somos bonecos disformes, artificiais e cheios de presunção"119. Essa temática irá habitar as pinturas e gravuras dos artistas Expressionistas com um tema recorrente. Argan registra com especial clareza a importância do elemento espiritual e mítico para o artista alemão, o Expressionista, cuja ansiedade metafísica expressa-se menos de maneira material ou cartesiana, e mais no campo do espírito. Diz Argan:

\footnotetext{
“A força mágica da arte cria de fato o sagrado, com sua técnica - tudo é ambíguo como a própria condição existencial do homem. A deformação expressionista não é caricatura da realidade, é a beleza que, ao passar da dimensão ideal à real, inverte seu próprio significado, convertendo-se em feiúra. Na poética expressionista, ainda assim fundamentalmente idealista, a condição humana é aquela do anjo caído. Há um duplo movimento: a queda e degradação do princípio materialista - é a ascensão e sublimação do princípio materialista, para unir-se com o espiritual - que determina o dinamismo, a essência dionisíaca, orgiástica e trágica da imagem, e seu duplo significado: do sagrado e do demoníaco, ${ }^{, 120}$.
}

Ainda sobre a diferença no modo de encarar a arte dos artistas latinos e alemães, cabe ressaltar que a arte se desenvolveu na França, em um Estado unificado e sedimentado há séculos, e essa estabilidade cultural - embora repleta de transformações

\footnotetext{
119 apud EKSTEINS, Modris, Op. cit., 1991, p. 117.

${ }^{120}$ ARGAN, Giulio Carlo, Op. cit., 1976, p. 288
} 
políticas - em torno de um idioma comum e uma linguagem simbólica comum, tornou Paris a capital das artes, em especial para os artistas de origem latina. A racionalidade, celebrada pelo iluminismo, aparecia como o caminho do sucesso para esses artistas que vinham de toda a parte do globo, a partir da segunda metade do século XIX em busca da liberdade para criar. Já no caso alemão, o desenvolvimento das artes ocorreu a despeito de não haver um país unificado, e de uma idéia de Alemanha ter sido, na maior parte do tempo até a segunda metade do século XIX, tratada como uma abstração. Enquanto para os artistas latinos, a racionalidade era o fio condutor do léxico artístico; para o alemão, a definição estética do indivíduo recaía sempre sobre bases míticas e espirituais. Desse modo, Ernst Ludwig Kirchner aponta:

\begin{abstract}
“A criatividade alemã é fundamentalmente diferente da criatividade latina. (...) O latino tira suas formas do objeto tal como existe na natureza. O alemão cria sua forma na fantasia, a partir de uma visão peculiar a ele mesmo. As formas da natureza visível lhe servem apenas de símbolos... e ele não procura a beleza na aparência, mas em algo além”121. p. 114.
\end{abstract}

Já no começo do século XX, essa geração de artistas dava forma ao movimento Expressionista nas artes plásticas. Cores fortes, formas distorcidas, melancolia e tristeza, uma pintura violenta e dramática. Na descrição de Argan: “Esse caráter [a violência] se conserva na pintura pela pasta densa da tinta a óleo, ou na mancha diluída da aquarela, na escultura com um bloco compacto de madeira talhada, e na pedra, pela fragmentação a martelo» ${ }^{\text {"122 }}$. Já a gravura, feita prioritariamente em madeira ${ }^{123}$, se difundia através de jornais, publicações e cartazes. Esse movimento trazia dentro de si questões sociais e humanas, que colocavam essa nova arte em completa oposição a arte “oficial”, ao invés do Naturalismo acadêmico, adotavam o naturalismo exacerbado. Logo surgiram grupos de artistas reunidos em torno de proposições estéticas e

121 apud EKSTEINS, Modris, Op. cit., 1991, p. 114.

${ }^{122}$ ARGAN, Giulio Carlo, Op. cit., 1976, p. 287.

${ }^{123}$ Xilogravura 
filosóficas, o primeiro deles foi o Die Brücke ${ }^{124}$. Mais tarde surgiu o Der Blaue Reiter $^{125}$, ambos ligados ao Expressionismo. Para esses grupos, nas palavras de Kandinsky, “a obra de arte é a expressão externa de uma necessidade interior”126.

A Grande Guerra evidenciou de forma ainda mais clara a divisão na sociedade alemã. A crença na vocação militar como chave para a afirmação e desenvolvimento alemão permeou a sociedade. A Guerra para acabar com todas as guerras era vista por grandes parcelas da população como uma forma de se redesenhar o equilíbrio europeu após a unificação da Alemanha. Desse modo, pode se observar o surgimento de uma arte pró-guerra, como era o caso da literatura de Ernst Jünger, e uma arte anti-guerra, cujo exemplo é o livro de Erich Maria Remarque, Nada de novo no Front. Norbert Elias assinala, “A controvérsia entre literatura pró-guerra e anti-guerra nos começos da República de Weimar refletiu uma das mais centrais e importantes controvérsias na Alemanha do período"127.

Os artistas expressionistas, defensores do indivíduo contra o sofrimento humano, se colocaram ao lado da arte anti-guerra, ainda que sem desprezar a existência da guerra como fenômeno humano. Nesse momento a gravura converteu-se em poderoso instrumento de ativismo e denúncia das cruezas do conflito. É notável o trabalho de Erich Heckel, que passou os anos da guerra em hospitais retratando soldados feridos através de xilogravuras. Sobre essa relação com a Guerra, diz Eksteins: “a fascinação pela violência representava um interesse pela vida, pela destruição como ato de criação, pela doença como parte da existência”,128.

\footnotetext{
124 “A Ponte”, movimento formado por Fritz Bleyl, Erich Heckel, Ernst Ludwig Kirchner, Karl SchmidtRottluff, Emil Nolde, Max Pechstein and Otto Mueller.

125 “O Cavaleiro Azul”, movimento formado por Wassily Kandinsky, Franz Marc, August Macke, Alexej von Jawlensky, Marianne von Werefkin, Lyonel Feininger e Albert Bloch. Durou entre 1911 e 1914 ${ }^{126}$ apud GUINSBURG, Jaco, Op. cit., 2002. p. 392.

${ }^{127}$ ELIAS, Norbert, Op cit, 1997. p. 194.

${ }^{128}$ EKSTEINS, Modris, Op. cit., 1991, p. 116.
} 
Com o fim da Grande Guerra, e, 1918, a Alemanha entrou em um novo período, marcado pela agitação social, pela abdicação do Kaiser Guilherme II e com o estabelecimento de uma república parlamentar baseada na liberdade e na livre iniciativa.

Com a República de Weimar, a sensação de liberdade para a expressão artística fez com que florescesse um momento singular nas artes de modo geral: o cinema, a arquitetura, a música, o teatro, a poesia e também a pintura eram áreas de experimentação de vanguarda. Por um momento a arte Romântica, tão característica da aristocracia do II Reich, parecia diminuída em meio a profusão de acontecimentos e experimentações modernas.

Nesse cenário, logo após a guerra surgem novos movimentos na arte alemã, também vinculados à estética do Expressionismo, dentre eles a Secessão de Dresden ${ }^{129}$, que regatava aspectos da arte expressionista de antes da Guerra, assumindo também temas como a pobreza e a guerra. Eksteins diz:

\begin{abstract}
"Se a idéia do espírito em guerra era fundamental para a auto-imagem da vanguarda européia de antes de 1914, a Alemanha como nação eram quem melhor representava essa idéia; e se para uma emergente estética moderna era fundamental questionar os padrões percebidos como predominantes no século XIX, a Alemanha era quem melhor representava essa revolta", ${ }^{\text {, }}$.
\end{abstract}

Por outro lado, a República de Weimar sofria com a instabilidade política. De modo geral, as crises econômicas e o fantasma sempre presente do tratado de Versalhes tornavam o regime político cada vez mais desacreditado. Para piorar a situação institucional na Alemanha, a tentativa de Revolução empreendida por Rosa Luxembourg em 1919 fez com que o medo da Revolução Social permeasse as classes médias e altas.

\footnotetext{
${ }^{129}$ Grupo de artistas formado por Conrad Felixmüller, Will Heckrott, Laser Segall, Otto Dix, Otto Schubert, Constantin von Mitschke-Collande e Hugo Zehder.

${ }^{130}$ EKSTEINS, Modris, Op. cit., 1991, p. 112.
} 
A desordem institucional e a falta de autoridade da república, propiciavam o surgimento de grupos políticos radicais, de direita e de esquerda, que ofereciam caminhos alternativos a democracia liberal que, no entendimento geral, fracassava. Nas artes, um grupo grande de artistas e intelectuais dos mais diversos campos se juntaram no Berliner Group, reunidos em torno da defesa da liberdade artística e intelectual, e principalmente na defesa dos artistas de vanguarda que eram muitas vezes alvos da violência dos Freikorps, por serem tratados como anti-patrióticos, desordeiros e, em ultima instância, degenerados.

Esse clima de instabilidade da República, combinado com uma liberdade artística inédita na história da Alemanha unificada, em um país com uma classe trabalhadora urbana em crescimento e ávida pelo consumo de bens de lazer; e uma elite intelectual e uma burguesia que foram rejeitadas durante o Império, ávidas pela afirmação cultural, ou pela expressão de uma Kultur mais em acordo com o código moral das classes médias. Fez com que surgisse um sem-número de demonstrações de vitalidade na cultura de Weimar, que refletia essa efervescência cultural - o debate ganhara uma nova roupagem com a liberdade experimentada pelos artistas. Sobre essa arte, diz Karin Thomas:

\footnotetext{
"Sempre quando encontramos o Zeitgeist (espírito do tempo) perambulando sem rumo, na arte, entre insegurança e nova transcendência após a virada do século, fala-se em arte expressionista, tendência fortemente marcada por uma postura apaixonadamente afirmativa, mais do que pela invenção de novos princípios formais. Entretanto, o páthos revolucionário que, apesar disso, marca o Expressionismo como arte moderna de vanguarda, não resulta de um conceito estilístico, mas da coragem de colocar o indivíduo, e sua vivência emocional, no centro da expressão artística, A realidade percebida pelos sentidos é para o Expressionismo o impulso que gera a experiência íntima, ou o símbolo de um estado d'alma específico. Assim, as obras expressionistas tornam-se um grito sublime do indivíduo que, embora impotente, luta pela sua libertação”131.
}

${ }^{131}$ THOMAS, Karin, Op. cit., 1944. p. 74. 
Esse debate pautou os anos da República. E nesse aspecto, a ascensão do Nazismo representou, a vitória de uma proposta estética específica. No que se tratava de artes, Hitler - ele próprio um artista fracassado - acreditava que, na busca por uma arte que fosse a real expressão da Kultur germânica, a arte verdadeira seria a arte do Romantismo, do Naturalismo acadêmico - ou mais do que isso, a obra de arte total (Gesamkunstwerk) de Wagner: uma proposta estética totalizante, que desse conta de cada aspecto da vida publica e privada do alemão.

Para Hitler, a arte moderna - um cenário no qual se destacavam os artistas imigrados do leste europeu, muitos dos quais judeus - era uma arte espúria, símbolo do caos social e da Revolução. Era também, o rompimento com seu aprendizado artístico e com o Romantismo aristocrático e militar que fizera do povo alemão bravo combatente nos campos de batalha. A arte moderna representava cosmopolitismo e pacifismo, em ultima instância, a capitulação e a humilhação de Versalhes. Já em 1922 isso estava claro no pensamento de Hitler, em um discurso em 18 de setembro ele disse: "Idéias como a de (...) 'Arte Internacional', e outras muitas, desintegram a nossa consciência de raça, geram a covardia, e hoje somos forçados a reconhecer que o próprio turco é mais homem do que nós”132.

Após chegar ao poder, Hitler passou a suprimir as manifestações artísticas publicas, peças, filmes e exposições de arte que ele julgava impuras e “enfermas”. Com o tempo, na sua estratégia de propaganda contra a arte moderna, o partido nazista passou a promover exposições e propagandas onde pinturas modernas eram colocadas ao lado de fotos de pessoas com defeitos físicos, com o intuito de evidenciar os descaminhos e as impurezas característicos dessa nova arte. No dia em que aprovou o decreto em que recebeu plenos poderes do Reichstag (Enabling Act), inaugurando um

\footnotetext{
${ }^{132}$ HITLER, Adolf, Op. cit., 1943, p. 48.
} 
Estado de exceção com a duração prevista de quatro anos, Hitler apontou sobre a arte em seu discurso:

\begin{abstract}
"Simultâneamente com esta política de purificação de nossa vida pública, o governo do Reich procederá um inteiro expurgo moral do corpo da nação. Todo o sistema educacional, o teatro, o cinema, a literatura, a imprensa e o rádio - tudo será empregado como um meio para este fim e dessa forma avaliado. Todos estes elementos devem servir para a manutenção dos valores eternos presentes no caráter essencial de nosso povo. A arte sempre ficará sendo a expressão e o reflexo dos anseios e das realidades de uma época. Atitude neutral e internacional de alheiamento está desaparecendo rapidamente. O heroísmo avança apaixonadamente e no futuro moldará e norteara o destino político. A tarefa da arte é ser a expressão deste espírito determinante da época. Sangue e raça serão mais uma vez a fonte de intuição artística"133.
\end{abstract}

Dentro dos órgãos da propaganda Nazista surgiu a idéia de se organizar uma grande exposição da “Arte Degenerada”, que seria contraposta a uma exposição da “Grande arte Alemã”, inaugurada um dia antes. Onde, por razões educativas, ficaria marcada a superioridade da segunda em relação a primeira, deixando clara a degeneração subversiva da arte moderna em contraposição com a arte Naturalista acadêmica do Romantismo.

Ambas as exposições foram originalmente apresentadas em Munique. A de “Arte Degenerada” foi aberta ao público no dia 19 de Julho de 1937. A exposição tinha como objetivo elencar toda a arte que era inaceitável para o III Reich, e que fora classificada como difamação “anti-alemãs”. Foram reunidas 650 obras de arte, entre gravuras, esculturas, pinturas e livros, retiradas das coleções de 32 museus públicos alemães. Na festa de inauguração da exposição, no dia 18 de julho, Hitler proferiu o seguinte discurso:

“Trabalhos de arte incompreensíveis e que necessitem de um sem-número de regras para provar seu direito de existência e chegar aos neuróticos abertos a tais

${ }^{133}$ Idem, 1943, p. 124. 
disparates estúpidos e insolentes, já não terão caminho por onde alcancem a nação alemã. Ninguém tenha ilusões. O Nacional-Socialismo propôs-se a expurgar o Reich alemão e o nosso povo de todas essas influências que lhe ameaçam a existência e o caráter. (...) Ou estes pretensos artistas vêem as cousas da maneiram como as representam, e neste caso será preciso pesquisar se a sua anormalidade provém de taras hereditárias ou de defeitos mecânicos, ou então eles próprios não acreditam na realidade dessas impressões e por outros motivos impingem à nação tais embustes; nesta hipótese, sua atividade é caso de polícia e de corte criminal”, ${ }^{, 134}$.

Durante os quatro meses em que a exposição esteve aberta em Munique, mais de quatro milhões de visitantes estiveram lá. Nos três anos seguintes, a exposição viajou pela Alemanha e Áustria, e foi vista por mais um milhão de espectadores. Isso fez dela a exposição mais vista em toda a história da arte moderna até então - e provavelmente até os dias de hoje.

Para além disso, mais de dezesseis mil obras de arte, classificadas como degeneradas foram confiscadas de particulares. Coleções inteiras de famílias judias muitas das quais apoiadoras dos movimentos ligados à arte moderna - foram expropriadas por um comitê capitaneado pelo ministro da propaganda Joseph Goebbels. Alguns desses trabalhos integraram o rol da arte degenerada, mas muitas outras foram vendidas para particulares de outros países, por valores compatíveis ao mercado internacional $^{135}$. Aquelas que não entraram na exposição e nem foram vendidas foram queimadas em frente ao departamento central dos bombeiros em Berlim, em 1939.

\footnotetext{
${ }^{134}$ Ibidem, 1943, p. 316.

135 Sobre o talento especial de Göering para negociar essas obras no Mercado internacional ver: PETROPOULOS, Jonathan, Art as Politics in the Third Reich, USA, University of North Carolina, 1996, p. 187.
} 


\section{Socialistas versus Socialistas: Partido da Ordem e Revolução na República de Weimar}

\subsection{O Partido da Ordem}

\footnotetext{
“Pessoas ‘progressistas’ podem, apesar de suas convicções políticas, eventualmente agir de maneira 'tradicionalista', ${ }^{336}$.
}

No contexto da Alemanha no nascimento da República de Weimar, podemos colocar dentro do Partido da Ordem, originalmente o extrato composto pelos Junkers, pela aristocracia - geralmente associada ao grande Estado Maior, cuja importância foi analisada no capítulo anterior -, pelos industriais do Rühr - que representavam a alta burguesia, donde se destacavam as famílias Thyssen, Siemens e Krupp - e pelo Partido do Centro Católico chamado Zentrum. Estes todos já se encontravam dentro do centro de decisão político do Império. A aristocracia e o exército tinham a primazia nas decisões durante o Império de Guilherme II, mas essas classes já permitiam aos grandes industriais uma participação relevante na política. Estes grupos continuaram próximos ao poder na República.

A possibilidade real da Revolução, após a Revolução Russa em 1917, os levantes em Berlim e na Bavária e o crescimento dos partidos comunistas, que estiveram contra a Guerra durante todo o tempo, fez com que grandes parcelas desses grupos, que estiveram nos centros de decisão do Império aceitassem a República parlamentar não por convicção, mas como uma alternativa menos lesiva para seus interesses do que a Revolução. Na República, ao menos a participação desses grupos na vida política estava assegurada.

\footnotetext{
${ }^{136}$ MANNHEIM, Karl, Op cit, 1959, p. 95. tradução livre de “'Progressive’ people for instance, regardless of their political convictions, may often act 'traditionalistically",
} 
Houve ainda, parcelas menores desses grupos que não aceitaram a Republica de imediato, colocando-se como arautos da idéia de retorno ao Império. A derrota na Guerra fora um golpe definitivo contra o Kaiser, já os tratados de paz fizeram com que se sepultasse em definitivo esses 'regressistas'. Restaram apenas como agitadores antirepublicanos, mas sem grande força política. Talvez o mais importante Regressista tenha sido o importante empresário prussiano Alfred Hugenberg. Membro do DNVP, Partido Nacional do Povo Alemão, desde 1918, ele se tornou líder do partido após as eleições de 1928, onde o partido experimentou uma derrota eleitoral, passando de 103 para 73 assentos no Reichstag. Essa derrota, na visão de Hugenberg, significava que o partido deveria se reorientar: até então era um partido monarquista e 'regressista'. Hugenberg conduziu o partido para perto de Hitler, quem admirava e de quem foi ministro da agricultura por um breve período em 1933.

Muito embora a derrota na I Guerra tenha significado uma derrota política para a aristocracia, para o exército e para os grandes industriais, estes grupos não se mantiveram afastados do poder no nascimento da República. Foi o Exército, através do General Groener que ofereceu ao líder Social Democrata Friedrich Ebert a segurança necessária para o estabelecimento da ordem e a proclamação da República, em troca disso o Partido Social Democrata manteria a estrutura do Exército. Em inúmeros órgãos da administração pública, não era possível criar uma nova burocracia de um momento para o outro: manteve a burocracia advinda do império, formada pelos antigos representantes do Partido da Ordem. Muitos historiadores viram nesse fato uma das mais evidentes fraquezas da República, de acordo com Peter Gay, "Houve erros estratégicos fatídicos, mas os homens de Weimar cometeram um erro ainda mais fatal, 
quando falharam em subjugar ou transformar o funcionamento da antiga ordem: os militares, os funcionários públicos e os tribunais”137.

Já segundo o estatístico E. J. Gumbel a República nascera derrotada na medida em que aceitara a burocracia do Império, em especial o Judiciário ${ }^{138}$, que ao longo dos primeiros anos da República aplicou penas de maneira não isenta: enquanto os infratores ligados à extrema-esquerda eram punidos com rigor exemplar, nos julgamentos dos infratores de extrema-direita, alertou Gumbel em 1924, "os documentos vão se avolumando, (...). As cortes estão trabalhando febrilmente. Inicia-se um processo após o outro. Cada um tem sua própria estrutura. Apenas o resultado é sempre o mesmo: os verdadeiros culpados permanecem impunes”139. Segundo os dados levantados por Gumbel, dos 354 assassinatos cometidos pelos grupos de extremadireita, "apenas um foi rigorosamente punido e nem mesmo esse, com a pena de morte" ${ }^{140}$. Na época, o Conde Kessler alertou para "o paradoxo de um governo Republicano social democrático permitindo-se aos cofres capitalistas serem defendidos por desempregados contratados e por oficiais monarquistas é simplesmente loucura em demasia”, ${ }^{141}$.

O Zentrum manteve-se próximo ao poder, assim como os Democratas, compondo o sustentáculo inicial da República junto ao SPD. A Social Democracia em 1918 era um partido acostumado ao jogo político parlamentar, consciente de sua posição majoritária no novo regime e bastante afastado dos ideais marxistas revolucionários. Conforme descreve Peter Gay:

\footnotetext{
${ }^{137}$ GAY, Peter, Op. cit, 1978, p. 33.

${ }^{138}$ GUMBEL, E. J., "Disarmament and Clandestine Rearmament under the Weimar Republic” in MELMAN, Seymour, Op. cit, 1958. p. 203-219.

${ }^{139}$ GUMBEL, E. J. apud GAY, Peter, Op. cit, 1978, p. 36.

${ }^{140}$ GAY, Peter, Op. cit, 1978, p. 35.

${ }^{141}$ Idem, 1978, p. 34.
} 
"O Imperador e seus adeptos estavam desacreditados; a liderança deveria vir dos socialistas. Mas que espécie de socialistas? O Partido Social-Democrata há muito tempo era um partido majoritário, mas mesmo antes de 1914 vinha havendo uma coalizão tensa, dividida entre os radicais que levavam o Marxismo revolucionário a sério, lideres sindicais que queriam esquecer a ideologia e buscar padrões mais elevados de vida para a classe trabalhadora, e funcionários que se comprometiam falando como revolucionários e agindo como parlamentaristas. A decisão da delegação do Partido para o Reichstag em 4 de agosto de 1914, de votar para os créditos de guerra em violação de seus princípios até então honrados, havia dilacerado essa estrutura além de qualquer conserto" ${ }^{\text {"142 }}$.

O Partido Social Democrata, preponderante quando do advento da República Weimar, passara todo o período do Império na oposição ao Kaiser, e fora o principal responsável pela instalação da República e pela elaboração da Constituição de Weimar. Desde 1912, o SPD era o partido com o maior número de assentos no Reichstag, conforme descreve Eksteins:

\begin{abstract}
“As eleições de 1912 produziram um resultado assombroso. As três tendências políticas que Bismarck, num ou noutro momento, chamara de "inimigos do Reich"e, portanto, de traidores - os liberais de esquerda, os católicos e os socialistas - ganharam dois terços do voto nacional. Um em cada três alemães votou a favor de um candidato socialista, e o SPD tornou-se de longe o maior grupo político do Reichstag”"143.
\end{abstract}

Mas devido a imobilidade do parlamento no período do Império, apenas com a República, essa força no parlamento se converteu de fato em poder político para o SPD. Ebert assumiu a chefia do Estado alemão após a abdicação do Imperador em 1918. O também social democrata Philipp Scheidemann proclamou a República em 9 de novembro de 1918. Em 19 de janeiro de 1919 houve o pleito para a assembléia constituinte, que uma vez instalada indicou Ebert para a presidência do Reich. Ebert, por sua vez, indicou Scheidemann para formar o governo como chanceler do Reich. O ministro do interior, o jurista Hugo Preuss ficou responsável pela redação da minuta da carta constitucional que foi submetida ao Reichstag.

\footnotetext{
142 Ibidem, 1978, p. 166.

${ }^{143}$ EKSTEINS, Modris, Op. cit., 1991, p. 103.
} 
Na elaboração da Constituição alguns problemas fundamentais estiveram colocados. Em primeiro lugar, Preuss estava preocupado em fortalecer o parlamento em contraposição ao poder do chefe de Estado, sem no entanto deixar que o parlamento vivesse a mesma paralisia que fora comum nos anos do Império. Dessa maneira, o mecanismo do plebiscito foi adotado como forma de resolver impasses legislativos. De acordo com Carl Schmitt:

"É o objetivo de toda Constituição sensata dar um sistema organizacional que possibilite uma volição estatal e um governo capaz de governar. É, sobretudo, a intenção consciente e bem refletida da vigente Constituição do Reich alcançar esse objetivo e todos os seus institutos de uma democracia parlamentar e plebiscitária devem, em primeiro lugar, criar um governo eficiente. Parte-se do princípio que um governo apoiado em camadas populares e que encontra a anuência e a aclamação do povo é mais forte e mais intenso do que os demais tipos de governo. Por essa razão, a primeira parte organizacional da Constituição do Reich contém, (...), um equilíbrio, em princípio, bem refletido da democracia parlamentar para com a plebiscitária”144.

Outro problema fundamental era a organização dos estados que compunham a o Estado Alemão. No Império, a configuração geográfica dos Länder (estados) correspondia às fronteiras dos Estados que haviam formado a Alemanha. Dessa maneira, a Prússia tinha a supremacia entre os Länder. Hugo Preuss, enxergava nessa configuração um dos principais vícios no sistema jurídico do Império ${ }^{145}$. De acordo com Peter Gay, “Preuss, bastante preocupado com a hegemonia da Prússia, queria destruir a antiga coleção federal de estados, retalhar a Prússia em inúmeros Länder e reunir

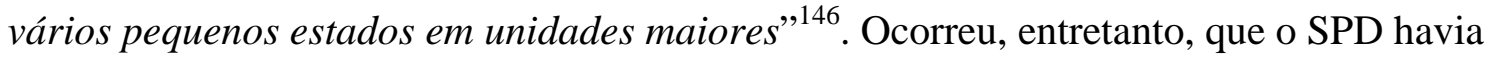
conquistado o governo do Länd da Prússia, o que fez que a Social Democracia fosse a principal opositora à mudança na configuração geográfica dos Länder. O modelo de Estado unitário, por sua vez, foi rejeitado pelo parlamento, temeroso que se repetisse na

${ }^{144}$ SCHMITT, Carl, O Guardião da Constituição, Belo Horizonte, Del Rey, 2007. p. 168.

${ }^{145}$ A esse respeito, ver GAY, Peter, Op. cit, 1978, p. 32; 169. Ver também STIRK, Peter M. R., "Hugo Preuss, German political thought and the Weimar constitution”, in History of political thought., 23 (3), Durham, University Library, 2002. p. 497-516.

${ }^{146}$ GAY, Peter, Op. cit, 1978, p. 32. 
República o excesso de poder nas mãos de um Executivo nacional - embora o Estado

Imperial fosse federativo -, característica fundamental do regime autoritário do Império.

Criou-se, de acordo com o defendido pelo SPD, uma República Federativa, mantendose o sistema dos Länder proveniente do Império ${ }^{147}$.

Por fim, o aspecto mais delicado da Constituição da República de Weimar foram as implicações do artigo 48 na vida política da República. O texto do artigo dispunha o seguinte:

\begin{abstract}
"Artigo 48
$1^{\circ}$. Caso um estado não cumpra as obrigações dispostas nas leis da Constituição do Reich, o Presidente do Reich poderá usar da força armada a fim fazer cumprir tal obrigação.

$2^{\circ}$. Caso a segurança e a ordem públicas sejam seriamente (erheblich) perturbadas ou feridas no Reich alemão, o presidente do Reich deve tomar as medidas necessárias para restabelecer a segurança e a ordem públicas, com ajuda se necessário das Forças Armadas. Para este fim ele deve suspender, total ou parcialmente, os direitos fundamentais [Grundrechte] definidos nos artigos 114, 115, 117, 118, 123, 124, e 153.

$3^{\circ}$. O Presidente do Reich deve informar o Reichstag imediatamente sobre todas as medidas tomadas baseadas nos parágrafos 1 e 2 do presente artigo. As medidas deverão ser suspensas imediatamente se o Reichstag assim determinar.

$4^{\circ}$. Se o perigo é iminente, o governo do estado [Länd] deverá, para manutenção do território, implementar o que prescreve o parágrafo 2 do presente artigo.

$5^{\circ}$. Estes passos devem ser suspensos se assim for determinado pelo Presidente do Reich ou pelo Reichstag"148.
\end{abstract}

De acordo com Carl Schmitt, o primeiro ponto importante do artigo 48 no

tocante às suas implicações é a possibilidade de surgimento de um legislador

\footnotetext{
147 “Artigo 2: O território do Estado do Reich é composto pelos território dos estados germânicos. Outras areas poderão ser incluídas no Reich, desde que sua população manifeste sua vontade para tal no exercício do seu direito de autodeterminação". Constituição da República de Weimar in

OPPENHEIMER, H., Constitution of the German Republic, London, Stevens \& Sons, 1921. tradução livre de "Article 2: State territory of the Reich is composed of the territories of the German states. Other areas may be included in the Reich, if their population desires in exercise of its right of selfdetermination".

${ }^{148}$ Artigo 48 da Constituição da República de Weimar in OPPENHEIMER, H., Constitution of the German Republic, London, Stevens \& Sons, 1921. tradução livre de "Article 48: If a state does not fulfill the obligations laid upon it by the Reich constitution or the Reich laws, the Reich President may use armed force to cause it to oblige. In case public safety is seriously threatened or disturbed, the Reich President may take the measures necessary to reestablish law and order, if necessary using armed force. In the pursuit of this aim he may suspend the civil rights described in articles 114, 115, 117, 118, 123, 124 and 154, partially or entirely. The Reich President has to inform Reichstag immediately about all measures undertaken which are based on paragraphs 1 and 2 of this article. The measures have to be suspended immediately if Reichstag demands so. If danger is imminent, the state government may, for their specific territory, implement steps as described in paragraph 2. These steps have to be suspended if so demanded by the Reich President or the Reichstag”.
} 
extraordinário através do regime de exceção previsto pelo artigo. Ainda que o governante não passe a legislar, Schmitt argumenta que, uma vez tendo o poder para, ao mesmo tempo, tomar as medidas necessárias para restabelecer a ordem através de decretos e aplicá-las, os decretos podem passar a ter força de lei, a partir de sua promulgação - desde que sejam tolerados (ou mesmo passem despercebidos) pelo Reichstag $^{149}$. O segundo aspecto importante que Schmitt levanta é no que diz respeito aos Direitos Fundamentais. De acordo com o artigo 48, o Presidente do Reich pode suspender parte ou todos os direitos fundamentais enumerados pelo artigo a partir da instalação de um estado de exceção. Este estado de exceção, por sua vez, pode ser instalado pelo Presidente do Reich se assim julgar necessário, e não tem limitações temporais nem regras para sua aplicação. Deste modo, argumenta Schmitt, o Presidente do Reich pode "se apoderar de um poder de fato, em virtude do qual não é preciso levar em consideração os direitos [fundamentais], que em seu caso concreto se opõe a tal poder [ilimitado]”,

Assim sendo, o Poder Executivo tem um importante instrumento de controle da vida social e do Estado, na medida em que com o acirramento dos conflitos, ou mesmo com a paralisia parlamentar advinda de um conflito partidário, o Presidente do Reich pode governar a partir de decretos e também suspender parte ou a totalidade dos Direitos Fundamentais. Dessa maneira, manteve-se presente na República a possibilidade da centralização do poder decisório no Poder Executivo, o que, combinada com o direito do Presidente do Reich de dissolver o parlamento e nomear o Chanceler do Reich, estabelecia um sistema parlamentar cujo controle constitucional a partir do sistema de checks and balances era limitado. Além disso o período do mandato presidencial, estipulado em sete anos, reforçava ainda mais a importância do Presidente

\footnotetext{
${ }^{149}$ SCHMITT, Carl, Legalidade e Legitimidade, Belo Horizonte, DelRey, 2007. p. 71-79.

${ }^{150}$ SCHMITT, Carl, La Dictadura, Madrid, Alianza, 2007, p. 260.
} 
no sistema político de Weimar, em detrimento do parlamento, cujo mandato era de quatro anos. De acordo com Ernst Fraenkel, o sistema político de Weimar "levou a um descrédito dos partidos políticos e indiretamente à ruptura da autoridade do parlamento. Insinuou, ao mesmo tempo, a existência de um partido governamental e de um Presidente do Reich que 'se mantinha acima dos partidos”,151. Carl Schmitt vai além, comparando as implicações do artigo 48 a um regime monárquico, onde ao governante cabe também o papel de legislar:

\begin{abstract}
"Se alguém, utilizando-se dos conceitos do Estado legiferante parlamentar tradicional e dos lemas de luta contra o direito autônomo do governo monárquico de promulgar decretos-leis, quiser criticar esse procedimento legislativo tão sumário, ver-se-á obrigado a horrorizar-se diante de tamanhas 'inconstitucionalidades","152.
\end{abstract}

Ao suspender os Direitos Fundamentais, celebrados nos artigos 114 (liberdade individual), 115 (inviolabilidade do lar), 117 (privacidade da correspondência, telefone, telegrama e telégrafo), 118 (livre expressão), 123 (livre associação), 124 (formação de clubes e organizações) e 153 (propriedade privada), o artigo 48 da Constituição de Weimar (ver íntegra do texto constitucional no Anexo 8.1.), se convertia em um mecanismo levava a Alemanha a um regime com características tão autoritárias quanto o Império. A idéia de impedir uma paralisia entre executivo e legislativo fazia com que a cara do Regime pouco mudasse. Um chefe do executivo com grandes poderes e longo mandato, e com o predomínio absoluto do Länd da Prússia sobre os demais estados da federação, fazia com que o cidadão não tivesse que fazer um esforço demasiado para se acostumar com o novo regime.

\footnotetext{
${ }^{151}$ Ernst Fraenkel, Die repräsentative und die plebiszitäre Komponente im demokratischen Verfassungsstaat apud STIRK, Peter M. R., "Hugo Preuss, German political thought and the Weimar constitution”, in History of political thought., 23 (3), Durham, University Library, 2002. p. 502. tradução livre de "It led to a discrediting of political parties and indirectly to the shattering of the authority of parliament. It insinuated at the same time the existence of a party government and a Reich President 'standing above parties'”.

${ }^{152}$ SCHMITT, Carl, Op. cit, 2007. p. 72.
} 
De fato, as razões fundamentais pelas quais será possível classificar o Partido Social Democrata (SPD) como representante do Partido da Ordem, estão no papel desempenhado pelo partido nos primeiros momentos da República: na elaboração da Carta Constitucional e na reação às tentativas de levante empreendidas durante a República: o Putsch liderado pelo jornalista Wolfgang Kapp; a tentativa de Revolução empreendida pela Liga Espartaquista de Rosa Luxembourg e Karl Liebknecht; e o Putsch de Munique liderado por Hitler e pelo General Ludendorff.

Na medida em que a Social Democracia, partido dominante na Assembléia que votou a Carta Constitucional, aprovou uma constituição que mantinha a configuração dos Länder do Império inalterados, fazendo prevalecer o domínio da Prússia sobre os demais Länder, fez que os grupos prussianos que estiveram ligados ao Império mantivessem seu poder na República. Assim como a aprovação do dispositivo do Artigo 48 abriu um precedente para que o Presidente do Reich pudesse ter poderes maiores do que o imaginado pelos legisladores da Constituição. Nesse sentido mantinha-se no poder executivo a possibilidade de adoção do caminho autoritário. Cabe ressaltar que o Artigo 48 foi, ao longo dos 13 anos da República, invocado mais de 250 vezes, das quais 130 foram nos primeiros quatro anos ${ }^{153}$. Dentre todas as vezes que foi invocado, a mais célebre de todas foi quando Hitler, após o incêndio do Reichstag, em 28 de fevereiro de 1933, invocou o artigo 48 e suspendeu os Direitos Fundamentais, incluindo o Habeas Corpus, depois, no ato votado pelo parlamento em 23 de março de 1933, Hitler solicitou a extensão dos seus poderes, passando a ser também o Presidente do Reich, ambas as medidas foram aprovadas pelo parlamento (ver o texto das medidas nos anexos 8.2. e 8.3.). De acordo com Agambem:

\footnotetext{
${ }^{153}$ SCHEPPELE, Kim Lane, "Law in a Time of Emergency: States of Exception and the Temptations of 9/11". University of Pennsylvania Journal of Constitutional Law, Vol. 6 , 2004, p. 1008.
} 


\begin{abstract}
““'Logo que tomou o poder (ou, como talvez se devesse dizer de modo mais exato, mal o poder lhe foi entregue), Hitler promulgou, no dia 28 de fevereiro, o "Decreto para a proteção do povo e do Estado”, que suspendia os artigos da Constituição de Weimar relativos às liberdades individuais. O decreto nunca foi revogado, de modo que todo o Terceiro Reich pode ser considerado, do ponto de vista jurídico, como um estado de exceção que durou 12 anos”154.
\end{abstract}

Assim a Social Democracia foi decisiva no estabelecimento de um Regime que não rompia com características fundamentais do Império, da mesma forma que, com a escassez de quadros, mantinha parcelas inteiras da burocracia que sobrevivera à Guerra e, principalmente, rejeitava discretamente o tratado de Versalhes no que dizia ao Exército, sendo anuente com seu funcionamento além do permitido ${ }^{155}$. Mantendo-se como defensora dessa República estabelecida pela constituição em 1919, o SPD converteu-se em importante facção do Partido da Ordem.

Ao analisar as características que saltam aos olhos do leitor da constituição da República de Weimar, estão as inegáveis conquistas programáticas no sentido do estabelecimento de garantias constitucionais aos direitos sociais da população. Se, por uma lado, a constituição celebrou juridicamente, uma série de inovações sociais no nascente Estado de Weimar, do ponto de vista prático, para que o pacto fundamental que sustentava a segurança e o monopólio da violência na República pudesse ser levado a cabo, a Social Democracia, desde os primeiros governos, pouco fez no sentido de converter em políticas públicas as garantias sociais contidas na constituição. Pelo contrário, não só o SPD se distanciou da implementação destas políticas públicas, como realizou mais e mais concessões ao exército, e os grupos sociais que dominavam o comando do exército, para que esse pudesse garantir a sobrevivência da República, constantemente ameaçada no período entre 1918 e 1923. Na reflexão de Herf sobre o

\footnotetext{
${ }^{154}$ AGAMBEM, Giorgio, Estado de Exceção, São Paulo, Boitempo, 2004, p. 12

${ }^{155}$ Como foi o caso da assinatura, em 16 de Abril de 1922 do Tratado de Rapallo, entre a URSS e a Alemanha, que celebrou a cooperação econômica e a renúncia às reparações de guerra entre os dois países, alem disso, o Tratado celebrava secretamente o direito da Alemanha treinar seus exércitos em território Soviético.
} 
dilema que o SPD enfrentou na tentativa de assegurar a existência da República nascente:

\begin{abstract}
"Provou-se impossível fazer oposição ao exército, aos junkers, aos grupos paramilitares de direita e aos anti-semitas,e ainda sobrepujar a inflação e evitar o colapso econômico e a fragmentação territorial sem romper com as forças prótrabalhistas que eram mais simpáticas às instituições políticas de Weimar. Por isso, aqueles cujos interesses sociais eram defendidos pela república [exército, junkers, classe média] detestavam suas instituições políticas, e os que podiam simpatizar mais com suas instituições políticas [trabalhadores de modo geral] estavam amargurados porque não haviam realizado os ganhos sociais que esperavam"”156.
\end{abstract}

A liderança exercida pela Social Democracia nos primeiros anos da República teve sua autoridade consistentemente minada pelas agitações e desordens sociais, a crise econômica e monetária e a campanha feita por Comunistas de Nacional-Socialistas contra o SPD. Essa liderança que foi sendo destruída paulatinamente significou derrotas sucessivas nas eleições após 1919. Em 1919 o SPD alcançou 37,86\% dos votos para o Reichstag, e o USPD (Social Democratas Independentes) mais 7, 62\% o que combinado somava 45,48\% dos votos totais para o Reichstag. Nas eleições de 1920, o SPD (21,92\%) e o USPD (17,63\%) combinavam 39,55\% dos votos. Nos anos seguintes essa votação caiu em 1924 para a casa dos 20\%, observando um pico de 29,83\% em 1928, e depois uma queda, chegando em março de 1933 com apenas 18,25\% dos votos (ver tabela no capitulo 1). Esses resultados eram análogos ao experimentados pelo partido nas eleições regionais e locais.

Com a queda na votação, a Social Democracia foi sendo afastada dos centros de decisão da Republica, principalmente a partir da morte de Ebert, em 1925. Foi parte da coalizão que sustentou Hindenburg, mas perdeu espaço político para os grupos que estiveram no comando desde o Império. A própria eleição de Hindenburg para

\footnotetext{
${ }^{156}$ HERF, Jeffrey. Op. cit., 1993, p. 34.
} 
presidente do Reich era uma demonstração clara e evidente de que as coisas haviam avançado pouco desde o fim da ditadura de Ludendorff ${ }^{157}$, nos últimos anos da Guerra. Hindenburg era um remanescente da aristocracia que estivera no comando do exército desde a Unificação.

Os grupos que estiveram no poder junto com a Social Democracia, representados por pessoas como Schacht e Von Papen, dentre outros, e seus partidos, como o Centro católico, nunca estiveram comprometidos com a República da maneira como o SPD esteve.

A destruição da República de Weimar está intimamente ligada à capitulação destas facções do Partido da Ordem que migraram para o lado dos que defendiam a Ordem, na medida em que passaram a desacreditar a República e os líderes republicanos. Enquanto a Social Democracia identificava na Revolução seu maior inimigo; a aristocracia e os industriais tiveram uma atitude dúbia em relação a Hitler, que conquistou cada vez mais o espaço político destes grupos do Partido da Ordem.

No final, a Social Democracia restou como único grande sustentáculo da República que se desfazia. Restou como único grupo político majoritário que se manteve na posição de Partido da Ordem, no contexto republicano. O SPD enfrentaria a inconsistência de capitular ao seu programa que visava transformar a sociedade que saíra da Guerra e do governo do Kaiser, para poder sustentar a Ordem jurídica da República, como bastião da legalidade. Herf argumenta que: "Por Weimar se constituir num esforço para estabelecer a democracia política sobre alicerces sociais conservadores, os social-democratas acabaram se voltando para a direita a fim de esmagar a ameaça de revolução proveniente da esquerda” ${ }^{\text {158 }}$.

\footnotetext{
${ }^{157}$ Termo utilizado por A. J. P. Taylor e Arthur Rosenberg para denominar o período em que o General Ludendorff este a frente do exercito no Império, entre 1916 e 1918.

${ }^{158}$ HERF, Jeffrey. Op. cit., 1993, p. 34.
} 
No momento em que Hitler foi empossado chanceler da República de Weimar, os eventos rapidamente levam ao golpe final contra a República da maneira em que ele previra em 25 de setembro de 1930, diante da Corte Federal em Leipzig:

“A Constituição apenas mapeia a arena de batalha, não os objetivos. Nós entraremos nas estruturas legais e dessa maneira faremos o nosso Partido um fator determinante. Não obstante, uma vez que possuirmos o poder constitucional, iremos moldar o Estado da forma que julgarmos necessária" ${ }^{\text {"159. }}$.

Com as eleições de 5 março de 1933, após o incêndio no Reichstag, os Nacional Socialistas obtiveram uma grande vitória eleitoral e, aliados ao Partido Nacional Alemão, conquistaram a maioria simples no Reichstag, mas não os 2/3 necessários para alterar a Constituição. Mas em 23 de março, o Centro Católico passa a apoiar o Partido Nacional Socialista, aprovando então um ato no parlamento que permite ao Executivo promulgar e revogar leis, inclusive em desacordo com a Constituição. Na reflexão de Peter Gay, “A República estava morta de todo, menos no nome, vítima de falhas estruturais, defensores relutantes, aristocratas inescrupulosos, assim como de industriais, um legado histórico de autoritarismo, uma situação mundial desastrosa e um crime deliberado" ${ }^{\prime 60}$.

\subsection{A Revolução}

No caso específico da história da República de Weimar a Revolução tem ligações profundas com as concepções de Lênin e Rosa Luxembourg nos grupos herdeiros do pensamento marxista. À concepção de Lênin estava ligada a III Internacional Comunista, que orientou os Partidos Comunistas em todo o mundo a partir

\footnotetext{
159 apud BRACHER, Op. cit, 1978, p. 245.

${ }^{160}$ GAY, Peter, Op. cit, 1978, p. 183.
} 
de 1919, no que dizia a suas concepções e métodos de ação. Já à concepção de Rosa estava ligada a tentativa de Revolução realizada pela Liga Espartaquista da qual ela era a líder ao lado de Karl Liebknecth. Lênin via a Revolução como um processo histórico de transformação social, visando a supressão do Estado criado pela classe dominante, e pela supressão das relações de propriedade em que se fundamentam os conflitos de classe. De acordo com Lênin, a Revolução seria comandada por uma vanguarda que vai a frente do proletariado (o Partido) e que será o embrião do Estado operário. Lênin diz sobre a Revolução:

\begin{abstract}
“A Revolução distingue-se precisamente da situação 'normal' dos interesses do Estado pelo fato de as questões litigiosas da vida pública serem resolvidas diretamente pela luta de classes e por uma luta das massas que vai até o recurso das armas. Não pode ser de outra maneira, pois as massas são livres e armadas. Resulta, desse fato essencial, que não basta, em período revolucionário, conhecer a 'vontade da maioria'; não, é preciso ser o mais forte, no momento decisivo e no lugar decisivo; é preciso vencer. (...) [em todas as grandes épocas revolucionárias] vemos inumeráveis exemplos que mostram uma minoria melhor organizada, mais consciente, melhor armada, impor sua vontade à maioria e vencê-la",161.
\end{abstract}

Rosa, por sua vez, aceitava, assim como Lênin, o objetivo da proposição marxista de suprimir o Estado burguês a partir da eliminação da propriedade privada, dizia:

“[A] Revolução é o ato de criação política da história de classe, a legislação [que se cria] outra coisa não é que a expressão política da vida e da sociedade (...) [é na] passagem de um dado período histórico, de dada forma de sociedade, a outra, que reside todo o segredo das transformações históricas pela utilização do poder político,"162.

Mas, ao contrário de Lênin, Rosa acreditava na necessidade do estabelecimento de uma mobilização constante das massas que, com consciência do seu objetivo, e através do seu entendimento do mundo, fará a Revolução.

${ }^{161}$ LENIN, Vladimir Ilich, Política, org. Florestan Fernandes, São Paulo, Ática, 1978. p. 68.

${ }^{162}$ LUXEMBOURG, Rosa, Reforma ou Revolução, São Paulo, Expressão Popular, 1999, p. 96. 
No final do século XIX, o Partido Social Democrata alemão passava por intensos debates teóricos em seu interior. As figuras de Bernstein e Kautsky se destacaram, então, realizando uma crítica à Revolução no interior do marxismo e colocando a possibilidade do socialismo como a "estrela guia” na luta por conquistas sociais pelo jogo da democracia parlamentar. Do outro lado, Rosa Luxemburgo combatia essa idéia "reformista” argumentando ser imprescindível a Revolução. Os debates no interior do Partido Social Democrata se agravariam até a I Guerra Mundial.

A grande cisão entre a Revolução e a social-democracia, porém, veio a ocorrer no parlamento alemão: a ala à esquerda da social-democracia - onde despontavam as figuras de Rosa Luxembourg e Karl Liebknecht -, alem de alguns outros líderes como Bernstein e Kautsky, foi contra a aprovação dos créditos de guerra para o governo, enquanto grande parte do partido foi favorável a eles e aprovou-os, sob a liderança de Ebert.

Foi a Liga Espartaquista que, em novembro de 1918 iniciou uma tentativa de Revolução em Berlim. O caos do fim da guerra, o descrédito das instituições, a falta de autoridade do governo provisório do príncipe Von Baden e a descrença no parlamento que se formara, faziam com que:

“Até fins de dezembro de 1918, a situação alemã, em aparência, era muito parecida com a que existiu na Rússia durante os meses seguintes a Revolução de Fevereiro. A disciplina do exército estava se desmoronado; por toda parte havia formado sovietes dos soldados, os oficiais haviam perdido seu poder incontestável de mando e com freqüência tinham suas ombreiras arrancadas; havia manifestações que enchiam as ruas; em muitos lugares flamejavam bandeiras vermelhas; a guarnição da capital era de pouco confiança; ao lado do governo estava o Soviete dos Operários e dos Soldados, encabeçado por um Conselho Executivo”163.

\footnotetext{
${ }^{163}$ NOLTE, Ernest, La Guerra Civil Europea, 1917-1945 - 2ª ed, México, D.F., Fondo de Cultura Econômica, 1994, p. 83. trad livre de "Hacia fines de diciembre de 1918, la situación alemana en apariencia era muy parecida a la que existió en Rusia durante los meses siguientes a la Revolución de Febrero. La disciplina del ejército estaba desmoronándose; por todas partes se habían formado soviets de los soldados, los oficiales habían perdido el poder incontestable de mando y con frecuencia les arrancaban las hombreras; había manifestaciones que recorrían las calles; en muchos sitios ondeaban banderas rojas; la guarnición de la capital era de poca confianza; al lado del gobierno fungía el Soviet de los Obreros y los Soldados, encabezado por un Consejo Ejecutivo".
} 
No mês seguinte, ainda durante o levante revolucionário, a Liga passou a se chamar Partido Comunista Alemão ${ }^{164}$ (KPD), aliando-se ao grupo dos Comunistas Internacionalistas da Alemanha (IKD). Nesse momento, a revolta contava com o incentivo de Lênin e dos demais líderes soviéticos, eufóricos com a tomada do poder na Rússia, a Alemanha seria o lugar que garantiria o sucesso da Revolução no mundo, por todo o significado econômico, político e histórico. Segundo Fernando Claudin, “Em 1919-1920, o problema não se apresentava com essa complexidade ante os dirigentes soviéticos. Toda sua vontade política pendia em uma só direção: a vitória da revolução alemã ${ }^{\text {"165 }}$. Mas com o regresso das tropas do exterior que, ao contrário da situação na Rússia em 1917, era ordenado e planejado, o exército retomou grande parte do seu poder de fogo e de sua ordem interna. Esse fato foi fundamental para que Groener pudesse oferecer a garantia da ordem e da segurança para a instalação da República.

Além da retomada de parte da sua força por parte do exército, o ministro Noske, já no começo de 1919 convocou os Freikorps com o intuito de garantir a ordem nas ruas da capital e das demais cidades tomadas pelo levante comunista. O efeito imediato foi o acirramento dos combates na rua, seguido pela derrota dos comunistas. Em seu ultimo editorial em 14 de Janeiro, Rosa Luxembourg lançou palavras otimistas sobre o papel das massas na Revolução alemã:

\footnotetext{
“Os dirigentes fracassaram. Mas (...) as massas são decisivas, a rocha sobre a qual se construirá o triunfo final da Revolução (...) ‘A ordem reina em Berlim!' dizem os capangas. Sua ‘ordem’ está edificada sobre a areia. Amanhã mesmo a
}

\footnotetext{
164 em alemão Kommunistische Partei Deutschlands.

${ }^{165}$ CLAUDIN, Fernando, La crisis del movimento comunista, Paris, Ruedo Iberico, 1970, p. 99. trad livre de "En 1919-1920, el problema no se presentaba con esa complejidad ante los dirigentes soviéticos. Toda su voluntad política se tensa en una sola dirección: la victoria de la revolución alemana”.
} 
Revolução voltará a se "levantar com calor” e vai proclamar o choque em sons de trombetas: 'Fui, sou e serei!’”166.

O fracasso do levante levou ao assassinato dos líderes e diversos quadros do partido, conforme relata Claudin, a Revolução, perdeu seus melhores quadros:

\begin{abstract}
"E sem dúvida os efeitos desta trágica experiência sobre o desenvolvimento posterior do partido e da situação alemã foi considerável. O partido sai ferido e decapitado, perde o melhor de seu núcleo dirigente: um teórico da estirpe de Rosa Luxembourg, Karl Liebknecht, seu líder mais popular, outro quadros de valor como Leo Jogisches e E. Levine, centenas de quadros médios. Não menos grave foi o que esta experiência demonstrou: a grande maioria do proletariado alemão estava firmemente ligado e dominado, política e ideologicamente, pela Social Democracia”,167.
\end{abstract}

Claudin lembra ainda que tanto na visão de Rosa Luxembourg quanto na de Liebknecht e também na de Levine, os levantes em Berlim e na Bavária eram precipitados, e as condições necessárias para a revolução não estavam presentes por completo: não havia apoio consistente das massas, e a precipitação do embate revolucionário serviu, segundo Claudin, mais aos interesses da burguesia e da Social Democracia, do que ao dos revolucionários, nas palavras de Engels, no já citado prefácio, “Compreende agora o leitor por que é que os poderes dominantes querem pura e simplesmente levar-nos para lá onde a espingarda dispara e o sabre talha?»168.

Após esse trauma, o KPD ficou sob a liderança de Paul Levi, a partir do segundo semestre de 1919. Sob a liderança de Levi, o KPD se aproximou da III Internacional Comunistas, passando a operar sob a esfera de influência do Partido Comunista

\footnotetext{
166 apud NOLTE, Ernest, Op. cit., 1994, p. 85. trad livre de "Los dirigentes han fracasado. Pero (...) las masas son decisivas, la roca en la que se construirá el triunfo final de la Revolución (...) ‘ ¡El orden reina en Berlín!’ Esbirros torpes. Vuestro “orden” está edificado sobre la arena. Mañana mismola Revolución volverá a 'levantarse con fragor’ y os sobresaltará al proclamar al son de trompetas: ‘ ¡Fui, soy y seré!’”. ${ }^{167}$ CLAUDIN, Fernando, Op. cit., 1970, p. 99. trad livre de "Y sin embargo La gravitación de esta trágica experiencia sobre el desarrollo ulterior del partido y de la situación alemana fue considerable. El partido sale desangrado y decapitado, pierde lo mejor de su núcleo dirigente: un teórico de la talla internacional de Rosa Louxembourg, Karl Liebknecht, su líder más popular, otros cuadros de valía, como Leo Jogisches y E. Levine, centenares de cuadros medios. No menos grave es lo que esta experiencia pone de manifiesto: la gran mayoría del proletariado alemán está firmemente encuadrado y dominado, política e ideológicamente, por la socialdemocracia”.

${ }^{168}$ Ver nota 53.
} 
Soviético - se distanciando do modelo teórico de Rosa e se aproximando do modelo leninista. Levi expulsou a ala da esquerda radical dentro do partido, que se recusava a atuar na democracia parlamentar, e mesmo estabelecer conexões com os sindicatos que apoiavam o modelo democrático. No período foi incorporada a direção do partido, junto a Levi, Clara Zetkin, importante ativista, que havia sido amiga de Rosa Louxembourg, que rompera com os Social Democratas Independentes.

Junto a Zetkin, Levi luta contra a ala mais radical dentro do partido, mas ambos acabam sendo substituídos na direção do partido por Brandler e Thalheimer em 1921. A substituição ocorre a partir de um novo entendimento dentro da Internacional Comunista de que as condições estavam sedimentadas para a o levante revolucionário. O levante, ocorrido em março de 1921 é um amplo fracasso e, após o seu fim, o KPD conta com metade dos 360 mil membros que estavam afiliados ao partido antes do levante.

A ala liderada por Levi e Zetkin se opõe veementemente ao levante, e Levi publica um manifesto contra as táticas da Internacional Comunista: sua expulsão, sob a legenda de renegado, é imediata. No terceiro congresso da Internacional Comunista, Lênin reconhece o erro da tentativa do levante na Alemanha, com bases muito próximas as defendidas por Levi, mas ainda assim o congresso aprova a expulsão de Levi com base no argumento de quebra da disciplina partidária. Mais além, a Internacional lança o entendimento de que se deve eliminar qualquer facção de dentro dos partidos comunistas.

A aplicação da NEP (Nova Política Econômica) na União Soviética, motivou o código de disciplina interna dentro da Internacional Comunista: na visão de Claudin, isso significou a imposição de uma norma partidária com relevância interna a URSS, para os outros partidos comunistas do mundo. Segundo Claudin, a imposição da rígida 
disciplina partidária significava a negação do modelo que se estabelecera no partido bolchevique desde $1903^{169}$. Ou seja, se proibia externamente o modelo que alcançara sucesso internamente.

Tanto a NEP quanto a assinatura do Tratado de Rapallo, em 16 de abril de 1922 se interpunham no caminho do apoio irrestrito da Internacional Comunista para a Revolução alemã. Se por um lado havia a avaliação de que as potencias ocidentais não aceitariam uma intervenção direta soviética na Alemanha, o que acarretaria uma nova guerra, com a qual a URSS não poderia arcara após o acumulo de feridas com a I Guerra Mundial e com a Guerra Civil. Por outro, desde que o Tratado de Rapallo fora assinado, a Alemanha de Weimar converteu-se no principal Estado capitalista aliado a URSS, promovendo uma troca de tecnologias - inclusive militar -, o treinamento militar e testes de novos equipamentos militares. Lênin antecipará já em 1918 essa possibilidade, ao escrever no texto "Sobre o imposto em espécie":

\begin{abstract}
"Se a revolução demorar mais tempo a "estalar” na Alemanha, nossa tarefa será assimilar o capitalismo de Estado dos alemães, dedicar todas as nossas forças para adotar-lo e não titubear diante de nenhum método ditatorial para acelerar a dita transferência da cultura ocidental a Rússia bárbara, sem vacilar em métodos bárbaros para lutar contra a barbárie”,170.
\end{abstract}

Enquanto a URSS fornecia seu território para cientistas e militares alemães, cuja atividade fora proibida pelo tratado de Versalhes, recebia em troca a tecnologia responsável pela industrialização do país e modernização dos equipamentos de seus exércitos. Estes dois elementos, na visão de Claudin, se constituíam como centrais na visão dos dirigentes da Internacional, diz ele:

\footnotetext{
${ }^{169}$ CLAUDIN, Fernando, Op. cit., 1970, p. 102.

170 apud NOLTE, Ernest, Op. cit., 1994, p. 85. trad livre de“Si la revolución se demora más tiempo en “estallar” en Alemania, nuestra tarea será asimilar el capitalismo de Estado de los alemanes, dedicar todas nuestras fuerzas a adoptarlo y no titubear ante ningún método dictatorial para acelerar dicha transferencia de la cultura occidental a la Rusia bárbara, sin vacilar en la aplicación de métodos bárbaros para luchar contra la barbárie”.
} 
"Os chefes bolcheviques da nova Internacional e do novo Estado [soviético] se encontravam, por conseguinte, diante de duas tarefas dificilmente conciliáveis: por um lado, deveriam organizar a Revolução contra o Estado alemão como objetivo prioritário na estratégia da revolução mundial; por outro, deveriam preservar a aliança com o Estado alemão (...), como objetivo prioritário da política externa da República Soviética”171.

Já no ano de 1923, O quarto congresso da Internacional Comunista adotou uma nova postura, incentivando os líderes comunistas a trabalharem junto à ala esquerda da Social Democracia. O entendimento inicial, de que uma tentativa de revolução poderia provocar uma nova guerra no continente, e que seria uma saída imprudente, mudou radicalmente a partir de junho de 1923. Com o agravamento da crise da hiperinflação na Alemanha, e a ocupação do Rühr pelos franceses, os líderes comunistas viam com olhos esperançosos a possibilidade do desencadeamento do levante revolucionário. Zinoviev, então presidente da Internacional, e Trotsky colocaram-se a favor do levante; do outro lado estava Stalin, que se colocou contra, sua carta a Zinoviev e Bukharin dizia: “Devem os comunistas alemães encaminhar-se a tomada de poder sem a Social Democracia? Estão maduros para isso? (...) Opino que se deve barrar os alemães e não empurrá$\operatorname{los}{ }^{172}$.

O levante de 1923 marcou, de fato, a grande derrota dos comunistas na tentativa de tomar o poder nos primeiros anos da República. A tentativa frustrada de apoiar o levante nas alas esquerdas dos governos sociais democratas da Saxônia, da Turíngia e nos sindicatos de trabalhadores das duas regiões. Os sindicatos, profundamente ligados à Social Democracia, rechaçaram o levante às vésperas da data planejada, e o KPD

\footnotetext{
${ }^{171}$ CLAUDIN, Fernando, Op. cit., 1970, p. 99. trad livre de "Los jefes bolcheviques de la nueva Internacional y del nuevo Estado se encontraban, por consiguiente, ante dos tareas difícilmente conciliables: por un lado, debían organizar la revolución contra el Estado alemán en tanto que objetivo prioritario de la estrategia de la revolución mundial; por otro, debían preservar la alianza con el Estado alemán (...), como objetivo prioritario de la política exterior de la república soviética”.

172 apud Idem, 1970, p. 103. trad livre de "¿Deben los comunistas alemanes encaminarse hacia la tomada del poder sin la socialdemocracia? ¿Están ya maduros para eso? (...) Opino que hay que retener a los alemanes y no empujarlos".
} 
suspendeu o levante, que já começara em Hamburgo, onde houve uma luta intensa até que os comunistas fossem derrotados. O Partido ficou ilegal entre novembro de 1923 e março de 1924.

Dentro da Internacional, o levante de outubro de 1923 ficou marcado como uma derrota expressiva da Revolução na Alemanha, muito embora o desempenho eleitoral do Partido Comunista Alemão (KPD) sido surpreendentemente bom: em 1920 o partido ocupara apenas 4 lugares no Reischstag, já em maio de 1924, após o levante, o partido conseguiu ocupar 62 cadeiras no parlamento. Apesar da vitória eleitoral, os líderes do KPD, Brandler e Thalheimer, foram considerados traidores pela Internacional Comunista. Segundo Claudin, houve uma confusão entre a existência de condições reais para a revolução, e a existência de um potencial para o desenvolvimento dessas condições - que era o caso em Weimar ${ }^{173}$.

O fracasso no levante serviu também para que a Internacional pudesse minimizar o poder do grupo que controlava o KPD até então. Brandler e Thalheimer eram vistos como defensores de um sistema partidário calcado na democracia interna, refutada pela Internacional. Ambos foram convocados pela Internacional e se mantiveram até 1928 na URSS assumindo postos burocráticos na Internacional Comunista. O fim do levante e o debate pela democracia interna no partido coincide diretamente com a disputa entre Trotsky e Stalin na URSS. Enquanto a esquerda do partido, onde estavam intelectuais mais velhos e antigos membros da Liga Espartaquista, se aproximam de Trotsky, um grupo liderado por Ernst Thälmann, e apoiado por Stalin, em 1925 toma conta da direção do partido. Entre 1926 e 1928, dezenas de líderes da esquerda do partido, antigos líderes e intelectuais são expulsos do partido. Em 1928, apoiado por Stalin, Thälmann ascende à liderança do partido. O

\footnotetext{
${ }^{173}$ Ibidem, 1970, p. 106.
} 
desfecho contra as antigas lideranças do partido se expressa de maneira clara no discurso de Stalin em 1928, “Camarada Thälmann: aceite você os serviços destes intelectuais, se é que querem servir a causa operaria; ou pode enviar-los a passeio, se é que querem manda a todo custo" ${ }^{174}$. E foi o que aconteceu, os intelectuais foram expulsos um a um do partido, por que tiveram, no dizer de Claudin, a "funesta mania de pensar" ${ }^{175}$.

Nos anos da República o KPD se converteu no maior partido Comunista fora da URSS, obtendo votações expressivas (acima de 10\% dos votos) e forte presença no Reichstag. Nas eleições presidenciais de 1932, Thälmann obteve pouco mais de 13 \% dos votos, ficando atrás de Hitler e do vitorioso Hindenburg. As disputas entre o SPD e o KPD não cessaram durante todo o período da República, nas palavras de Bernstein “Socialistas contra Socialistas”176. Essa disputa remanesceu até o momento da tomada do poder Nacional Socialista, desviando o foco dos partidários da Revolução do combate ao fenômeno do Nazismo. A esse respeito, Trotsky dirá em 1930:

\begin{abstract}
“Que 'defenderá' o PC $[K P D]$ ? A constituição de Weimar? Não, deixamos essa tarefa a Brandler. O PC deve tomar a defesa das posições materiais e intelectuais que a classe operaria conquistou no Estado alemão. O problema que se apresenta imediatamente é o da sorte de suas organizações políticas, de seus sindicatos, de seus jornais e tipografias, seus clubes e bibliotecas etc. O operário comunista deve dizer ao operário social-democrata: 'Os políticos de nossos partidos são inconciliáveis; mas, se os fascistas vierem esta noite fazer um pogrom no local de tua organização, então, eu irei em teu auxílio, de armas na mão. Prometes vir, em meu auxílio, se o perigo ameaçar minha organização?' Tal é a quinta essência da política no período atual. Toda a agitação deve ser realizada nesse espírito"177.
\end{abstract}

A partir de junho 1929 , com o $12^{\circ}$ congresso do KPD, seguindo a recomendação de Stalin de abril de 1929, os comunistas alemães apontam a Social Democracia como

\footnotetext{
174 apud Ibidem, 1970, p. 110. trad livre de "Camara Thälmann: acepte usted los servicios de esos intelectuales, si es que quieren servir a la causa obrera; o puede enviarlos a paseo, si es que quieren mandar a toda costa”.

175 Ibidem, 1970, p. 111.

${ }^{176}$ GAY, Peter, Op. cit, 1978, p. 25.

177 TROTSKY, Leon, Op cit., 1979, p. 58.
} 
principal inimiga do comunismo, iniciando uma política de confrontação com os Social Democratas. Em outubro, com a crise da bolsa de Nova Iorque, e um novo período de crise econômica na Alemanha, A Internacional Comunista identifica o surgimento de um novo período onde as condições para a Revolução estariam presentes. Mas, nesse momento, conforme argumenta Claudin, as condições favoráveis se converteram em solo fértil para o crescimento do Partido Nacional Socialista, “[a crise de 1929] não produz o auge revolucionário que Stalin da por existente desde 1927, senão o auge espetacular do fascismo" ${ }^{\text {178 }}$. O dado fundamental é de que o operariado alemão, depois dos levantes sucessivos dos primeiros anos da república não se identificou com os comunistas, remanescendo próximo à Social Democracia: em janeiro de 1931, apenas 4\% dos comitês das fabricas tinha lideranças comunistas, enquanto 84\% eram controlados pela Social Democracia. Trotsky aponta esse fato com clareza ao comentar a manutenção da situação do partido na Alemanha após a crise:

\footnotetext{
"Isso quer dizer que os operários que ficaram com a social democracia, como os que voltaram desta vez com os nacional-socialistas, agiram, assim, não por simples ignorância ou porque só ontem tivessem despertado, mas porque se basearam na sua propria experiência dos últimos anos e não acreditam mais no PC [KPD]"179.
}

A partir de então os comunistas experimentam um leve crescimento nas suas votações, mas as tentativas de revolução nas ruas, as manifestações publicas são cada vez mais suplantadas pelos Nacional Socialistas. Até que, em 16 de julho de 1932, com o fim da proibição às SA e SS, os confrontos nas ruas colocam os comunistas em ampla desvantagem diante da violência dos grupos nazistas. Ainda assim, a violência dos grupos nazistas promoveu um crescimento eleitoral do KPD nas eleições em fins de 1932; somados com os votos da Social Democracia, os dois partidos tinham mais de um

\footnotetext{
${ }^{178}$ CLAUDIN, Fernando, Op. cit., 1970, trad livre de "[a crise de 1929] no se produce El auge revolucionario que Stalin da por existente desde 1927, sino el auge espectacular del fascismo”. 179 TROTSKY, Leon, Op cit., 1979, p. 46.
} 
milhão de votos e 30 cadeiras a mais no Reichstag do que os Nacional Socialistas. Mas ainda assim os partidos permaneceram desunidos, travando batalhas um contra o outro. Em março de 1933 o partido é caçado, pelo já chanceler Adolf Hitler, pouco depois o mesmo acontecerá com a Social Democracia. Será a derrota da Revolução na Alemanha, diante da novidade do movimento Nacional Socialista. 


\title{
5. A Ordem como proposta reorganizadora
}

Em nossa categorização entenderemos como Intérpretes da Ordem os grupos que, ao irão se cristalizar em torno do Partido Nacional-Socialista do Trabalho Alemão (NSDAP) e da figura de Adolf Hitler. Não era exclusivo dos Nacional-Socialistas o desejo de mudança evolucionária, a vontade da destruição da República e a criação de uma nova ordem baseada na organização e disciplina, elementos próprios da formação cultural e do nacionalismo alemão que triunfara em 1871. Essa oposição à República se manifestava abertamente nos meios de imprensa e nas manifestações populares. De acordo com Peter Gay, em setembro de 1928 na seção Brandenburg do Stahlhelm um dos grupos que se opunha a Republica, fundado por veteranos da I Guerra, proclamou:

\begin{abstract}
"Nós detestamos o atual regime; ele tornou impossível para nós libertar a nossa Mãe Pátria escravizada, destruir a mentira do complexo de guerra e conquistar o necessário Lebensraum no oriente. Nós declaramos guerra contra o sistema que atualmente governa o estado e contra todos aqueles que apóiam esse sistema, por uma política de compromissos"180.
\end{abstract}

Mas foi no Nacional Socialismo que a Ordem encontrou sua versão definitiva na República de Weimar. Hitler e os Nacional-Socialistas souberam fazer convergir em seu discurso elementos que foram determinantes para a sua ascensão. Conforme explica Jeffrey Herf ao encarar Hitler como revolucionário conservador, o Nacional-Socialismo tinha aquilo que de fundamental caracterizava a Ordem na Alemanha desde o século XIX, a sua aversão aos princípios iluministas celebrados com a Revolução Francesa de 1789, segundo Herf:

"Do mesmo modo que os ideólogos do Völkisch do século XIX, os revolucionários conservadores buscavam uma revolução político-cultural que revitalizasse a nação. Eram reacionários porque se opunham aos princípios de 1789 e, no entanto,

180 apud GAY, Peter, Op. cit, 1978, p. 176. 
encontravam no nacionalismo uma terceira força, "além” do capitalismo e do marxismo" ${ }^{\prime 181}$.

O movimento Nacional-Socialista surge junto ao nascimento da República de Weimar após a derrota Alemã e a assinatura do Tratado de Versalhes. Hitler aderiu ao pequeno Partido do Trabalho Alemão (DAP) em julho de 1919 e logo se tornou um dos líderes do Partido. Em 1920, o Partido passa a se chamar Partido Nacional Socialista do Trabalho Alemão (NSDAP). No ideário de Hitler e do Partido Nacional Socialista do Trabalho Alemão pode encontrar-se um conjunto de propostas - que refletem uma ideologia - que remetem ao mesmo tempo à negação do pensamento social próprio de pensadores da Europa Ocidental, por um lado; e, por outro, a uma vontade de mudança e modernização. Segundo Thomas Mann,

\footnotetext{
“o aspecto verdadeiramente característico e perigoso do nacional-socialismo era a mescla que fazia de robusta modernidade com uma postura positiva rumo ao progresso, associadas a sonhos do passado: um romantismo altamente tecnológico"182
}

No contexto em que surge, tendo como modelo de êxito a unificação realizada por Bismarck meio século antes; e como medida do fracasso a derrota na I Guerra Mundial e a humilhação de Versalhes, o movimento nacional-socialista tem como um de seus temas centrais o fortalecimento do Estado alemão. Diz Herf:

"Exigiam [os nazistas] uma revolução de direita que restaurasse o primado da política e do Estado sobre a economia e o mercado e, por meio disso, restaurasse os laços entre o romantismo e o rearmamento na Alemanha"183

O primeiro dos elementos que provocou a ascensão do partido, como aponta Elias Canetti, foi a repetição exaustiva da oposição do movimento Nacional Socialista

\footnotetext{
${ }^{181}$ HERF, Jeffrey. Op. cit., 1993, p. 24.

182 MANN, Thomas, “Deutschland und die Deutschen” apud HERF, Jeffrey. Op cit, 1993, p. 14.

${ }^{183}$ Idem, p. 14.
} 
contra o “ditame” de Versalhes ${ }^{184}$. Versalhes tocava em um ponto nevrálgico do sentimento do povo alemão. Misturava a dor da derrota, a humilhação das reparações financeiras e territoriais e, mais do que tudo, a restrição ao Exército, símbolo da coesão social do Estado alemão. Ao ser limitado a apenas cem mil homens, e ter o Estado Maior desativado pelo Tratado de Versalhes, o alemão perdia seu núcleo de coesão social, pois já não seria mais possível que todo alemão em idade militar pudesse atender ao exército, onde ele seria impingido do rígido código de honra e disciplina que era próprio do Exército, “A proibição do exército foi como a proibição de uma religião”185.

Ainda de acordo com Canetti, foi a restrição ao exército que significou, simbolicamente, o espaço para a ascensão do Nacional Socialismo. Diz ele,

\begin{abstract}
"O partido substitui o exército, e, ao primeiro, não se impõem fronteiras no interior da nação. Cada alemão - homem, mulher, criança, soldado ou civil - pode tornarse um nacional-socialista; com freqüência, seu interesse faz-se ainda maior se, no passado, ele não foi soldado, porque desse modo logra compartilhar de atitudes que normalmente lhe eram vedadas" ${ }^{\prime 186}$.
\end{abstract}

A novidade que o Partido Nacional Socialista representava, simbolizava para cada um de seus adeptos a possibilidade de uma nova inserção em um núcleo social, livre dos estigmas e fracassos de sua vida anterior, os adeptos do Nazismo se apegavam ao movimento como se a transformação que Hitler propunha à sociedade alemã fosse, também, a transformação do papel desses extratos médios da sociedade alemã na história da nação. Ao analisar a história de Adolf Eichmann, membro do partido e responsável pelas deportações dos judeus durante o regime Nacional Socialistas, Hannah Arendt analisa essa novidade que significava o movimento nazista:

\footnotetext{
${ }^{184}$ Em alemão o Diktat.

${ }^{185}$ CANETTI, Elias, Op. cit, 1995, p. 181.

${ }^{186}$ Idem, 1995, p. 181.
} 
"De uma vida rotineira, sem significado ou conseqüência, o vento o tinha soprado para a História, pelo que ele entendia, ou seja, para dentro de um Movimento sempre em marcha e no qual alguém como ele - já fracassado aos olhos de sua classe social, de sua família e, portanto, aos seus próprios também - podia começar de novo e ainda construir uma carreira"

O segundo aspecto presente no discurso Nacional Socialista que conquistou grande popularidade durante a ascensão de Hitler ao poder foi a combinação entre antisemitismo, o combate à inflação e a legenda da punhalada pelas costas. Segundo Winston Churchill, em um esforço para entender a figura de Hitler:

\begin{abstract}
"Como num sonho [para Hitler], tudo se fez repentinamente claro. A Alemanha fora apunhalada pelas costas e aprisionada nas garras dos judeus, dos aproveitadores e dos conspiradores que operavam atrás da linha de frente, dos malditos bolcheviques em sua conspiração internacional feita por intelectuais judeus. (...) viu seu dever: salvar a Alemanha dessas pragas, vingar-lhe as injustiças sofridas e conduzir a raça superior a seu destino há muito decretado”. ${ }^{188}$
\end{abstract}

Esse clima de descrença na Republica, que perpassava grandes camadas da sociedade alemã, era um ambiente propenso ao surgimento de grupos que oferecessem alternativas não apenas administrativas, mas ao modelo como um todo - como era o caso dos Comunistas e Nacional-Socialistas. Em uma carta enviada a Felix Gilbert em 18 de fevereiro de 1933, o historiador Theodor E. Mommsem escreveu, "estamos em um momento de revolução latente; a crise virá em breve»"189. O Nacional-Socialismo conseguiu, ao longo dos anos da República, se destacar dentre os grupos que se opuseram ao regime republicano e à Revolução. Dessa maneira, entenderemos como Intérpretes da Ordem o próprio Partido Nacional-Socialista, a quem se convencionou

\footnotetext{
${ }^{187}$ ARENDT, Hannah, Eichmann em Jerusálem, São Paulo, Cia das Letras, 1999. p. 45.

${ }^{188}$ CHURCHILL, Winton S, Memórias da Segunda Guerra Mundial- $2^{a}$ Ed, Rio de Janeiro, Nova Fronteira, 1995. p. 29.

${ }^{189}$ MOMMSEN, Theodor E. apud GILBERT, Felix, A European Past, New York, W. W. Norton \& Company, 1988, p. 128. tradução livre de "We're in a state of latent revolution; the crisis will come soon”.
} 
chamar de Nazistas ${ }^{190}$. Desde o nascimento da República, a desilusão de determinados grupos com o novo Estado, e a repulsa ao retorno à monarquia Guilhermina propiciou a afirmação do ideal da Ordem. De acordo com Peter Gay,

\begin{abstract}
"Os novos conservadores começaram a desprezar precisamente as inovações que a Revolução [derrubada do Kaiser e nascimento da República] introduziu; por seu lado, os radicais eram contra os remanescentes deixados pelo Império. Parece que a República de Weimar era demasiado bem sucedida para satisfazer seus críticos e não tão bem sucedida a ponto de satisfazer seus simpatizantes. Já no princípio de dezembro de 1918 Rilke havia perdido toda a esperança. 'Sob a aparência de uma grande revolta, persistia a antiga falta de caráter"”191.
\end{abstract}

É importante entender que os Nacional-Socialistas representavam uma novidade, característica do Século XX. Seu discurso voltava-se para a centralização da economia nas mãos de um Estado que funcionasse organicamente, eles viam no Partido a estrutura necessária para substituir o aparato de Estado da República. Hitler era um homem voltado à organização e à técnica. É bastante exemplar disso a resposta de Hitler, quando lhe foi sugerido que desfilasse a cavalo em um comício. Para ele era ridículo; desfilaria em um automóvel. Segundo Herf,

“Quando [os Nazistas] (...) tratavam os trens como corporificação da vontade de poder ou quando viam a alma racial expressa nas Autobahnen, estavam popularizando aquilo que até então estivera reservado à vanguarda cultural”192 .

O Partido Nacional-Socialista havia assimilado o passado, na medida em que percebia importância do Exército e dos códigos de disciplina dele advindo, nos quais se espelhava a sociedade na Prússia e, posteriormente, na Alemanha. Esses códigos tinham um papel determinante na formação de um indivíduo que respeitava a tradição e a hierarquia, valorizava a disciplina e a ordem. O próprio Hitler, ciente do significado dos

\footnotetext{
${ }^{190}$ O termo "Nazista" surgiu da abreviação do nome do Partido Nacional-Socialista em alemão, Nationalsozialistische Deutsche Arbeiterpartei (NSDAP). Em alemão a abreviação se tornou "Nazi”, em português convencionou-se usar o termo "Nazista".

${ }^{191}$ GAY, Peter, Op. cit, 1978, p. 23.

${ }^{192}$ HERF, Jeffrey, Op cit, 1993, p. 25.
} 
valores tradicionais que estavam presentes na formação do ethos alemão, profere as palavras “sangue”, “autoridade”, “espírito de luta” e “direitos vitais”, ao rejeitar o papel da constituição como finalidade última da política Nacional Socialista, diz ele:

\begin{abstract}
“As constituições nunca poderão fixar para sempre o caráter de uma finalidade política, especialmente quando essa finalidade não se identifica com os direitos vitais de um povo. (...) Do sangue, da autoridade pessoal e do espírito de luta gerase um valor que, ele e só ele, habilita um povo a olhar em torno de si com alegre confiança, e que é também a condição única da vida almejada pelo povo. E quando isso se realizar, também se tornará realidade aquilo por que lutam hoje os partidos políticos: prosperidade, felicidade do indivíduo, da vida familiar, etc."193.
\end{abstract}

Nessa seqüência do discurso, falado em 16 de setembro de 1930 em Munique,

Hitler, concordando sobre aquilo que Burke sobre o respeito aos antepassados, e com a importância do processo a que chamamos de evolucionário, Hitler coloca como seu fim, a mudança no estado das coisas, para que se possa "retornar ao estado das coisas" onde os alemães vivam com “o coração cheio de alegria”, a disciplina e a ordem são os elementos fundamentais que provocam a alegria no ser alemão, diz Hitler:

\begin{abstract}
"Primeiro havemos de ter honra e depois liberdade, e de ambas nascerá então a felicidade, a prosperidade, a vida: numa palavra, retornará aquele estado de coisas que nós, os alemães, visualizávamos talvez vagamente antes da guerra, um estado de coisas em que os homens poderão novamente viver com o coração cheio de alegria, porque sua vida terá um sentido e um propósito, e o termo da existência não será mais o fim de tudo, visto como depois dela se estenderá uma cadeia infinita de gerações"194.
\end{abstract}

Hitler, assim negava, a constituição e o Estado de direito como fins últimos da política. Procurando na personalidade, no individuo o caráter fundamental de um povo e o motor de ação da política. Mais uma vez concordando com Burke sobre o respeito aos antepassados, embora, por outro lado, negando por completo o modelo democrático parlamenta, e não tocando em nenhum momento no retorno ao modelo imperial. Em um

\footnotetext{
${ }^{193}$ HITLER, Adolf, Op. cit., 1943, p. 80-81.

${ }^{194}$ Idem., 1943, p. 81.
} 
discurso em 27 de Janeiro de 1932, no Clube Industrial de Düsseldorf, Hitler expôs para uma restrita platéia de grandes empresários, aquilo que pensava sobre a política e seu programa para a Alemanha. Estes empresários, um ano depois, iriam apoiar sua nomeação para chanceler. Tratando de defender mais uma vez a herança dos antepassados, ele diz que considera como um dos três fatores essências para a vida política de um povo "o seu valor intrínseco, que, como propriedade hereditária, se transmite de geração em geração - um valor que se modifica quando o povo, guardião de seus bens hereditários, se altera na sua composição íntima condicionada pelo sangue”, no entanto, Hitler acrescenta “enquanto sua natureza íntima não sofreu nenhuma alteração essencial”195. E finalmente concluindo essa parte do discurso, Hitler prega contra Weimar, a República e a Democracia, com argumentos que todos aqueles não simpáticos a República haviam transformado em bordão:

\footnotetext{
"Vejo dois princípios diametralmente opostos: o princípio da democracia que, por toda a parte onde se lhe permite produzir efeitos práticos, é o princípio da destruição; e o princípio do valor da personalidade, que eu chamaria de princípio construtivo, porque tudo aquilo que o homem realizou no passado, todas as civilizações humanas, só são concebíveis se admitirmos a supremacia desse princípio. O valor de um povo, o caráter de sua organização interna, por meio da qual esse valor pode produzir seus efeitos, e o caráter da educação de um povo são esses os pontos de partida da ação política; são estas as bases do êxito de tal ação" ${ }^{196}$.
}

Havia também o respeito ao papel crucial que o Exercito desempenhara na manutenção da ordem em oposição à Revolução no século XIX, na medida em que aparecia como o arauto do pensamento romântico e anti-iluminista, representando a evolução em contraposição a Revolução. Conforme descreve Mannheim a respeito do processo de reação contra as mudanças defendidas pelos revolucionários alemães de 1848:

\footnotetext{
${ }^{195}$ Ibidem, 1943, p. 84.

${ }^{196}$ Ibidem, 1943, p. 88.
} 
“O caráter evolucionário do desenvolvimento alemão, por outro lado, se assentava em uma forte pressão dos grupos no poder sobre as classes baixas, para prevenir a revolução. A existência de uma forte rejeição interna contra distúrbios de todos os tipos esta, de maneira quase certa, ligado ao fato de que a organização militar constituía o núcleo do corpo social alemão. (...) E isso significava um forte apoio ao movimento conservador e ao seu desenvolvimento emocional e intelectual”, ${ }^{\text {" }}$.

Gumbel, reitera a importância dos métodos militares empregados pelas organizações nazistas, como a SA e a SS, e pelo próprio partido como um diferencial que ajudou a transformar a imagem dos Nacional Socialistas de um movimento violento, como os Freikorps, em um partido cujas pretensões políticas eram sérias.

"Os Nazistas iniciaram como um movimento das parcelas excluídas da sociedade, o Lumpenproletariado, e os há muito desempregados. Esse movimento, originado por homens desesperados com muito pouco a perder, ganhou uma face de fanatismo político e terrorista. Nesse caso, os métodos militares foram de suma importância para o uso do partido em sua luta pela supremacia política”"198.

Mas tudo isso era apenas um alicerce para uma proposta nova, característica do século XX. A percepção de que a sociedade no século XX está fundada nas relações de classes, perpassa não somente os partidários da Revolução, mas também os intérpretes da Ordem, para os quais esse reconhecimento é fundamental, conforme argumenta Mannheim: “o tradicionalismo só pode se tornar conservadorismo em uma sociedade onde as mudanças ocorram a partir dos conflitos de classe - em uma sociedade de

\footnotetext{
${ }^{197}$ MANNHEIM, Karl, Op cit, 1959, p.80-1. tradução livre de “The evolutionary character of German development, on the other hand, rested on the strong pressure of the ruling groups on the lower strata, preventing the revolution. The existence of this strong barrier against internal disturbances of all kinds is almost certainly connected with the fact that the military set constituted the nucleus of the German social body. (...) And this meant a strong backing for both conservative movement and its intellectual and emotional development”.

198 GUMBEL, E. J., "Disarmament and Clandestine Rearmament under the Weimar Republic” in MELMAN, Seymour, Op. cit, 1958. p. 203-219. tradução livre de "The Nazis started as a movement of the outcasts of society, the Lumpenproletariat_long-standing unemployed. This movement, originating with desperate men who had little to lose, took on a politically fanatic and terroristic character. Here, military methods were important for use in the party's struggle for political supremacy”.
} 
classes. Esse é o pano de fundo do conservadorismo moderno" ${ }^{\text {"199 }}$. Cabe ressaltar que no cenário alemão, a Ordem mais uma vez ganhava sua força junto aqueles que desejavam mudanças na sociedade, rejeitando a República; mas que tinham profundo desdém pela perspectiva da Revolução, para eles simbolizada pelo Comunismo. O Partido NacionalSocialista tomou para si a iniciativa de combater a ameaça do Comunismo, colocandose como o bastião da reorganização social, contra a “desordem”, o “caos” e a "anarquia” dos Comunistas. Conforme relata Peter Gay,

\begin{abstract}
"Em outubro de 1931 os nazistas ampliaram sua influência na direita numa manifestação em Harzburg, assistida por nazistas proeminentes, industriais como Thyssen e Hugenberg, militares como Seeckt, financistas como Schacht. Criou-se uma frente "nacional" contra o Bolchevismo - uma combinação fatal, embora ainda frágil, unindo o poder do dinheiro, a habilidade política, o apelo às massas e a ambigüidade aristocrática”200.
\end{abstract}

Havia, no entanto, como argumenta Karl Dietrich Bracher, um respeito grande às mudanças legítimas e à legalidade no interior da Alemanha. E justamente pelo fato de Hitler se anunciar como inimigo da desordem e da Revolução Comunista, ele conquistou muita popularidade. Segundo Bracher, Hitler percebera que embora os primeiros quatro anos da República tivessem sido cambaleantes - com a crise da inflação e o caos social - as tentativas de levantes contra o regime, empreendidos pelos Espartaquistas, por Kapp e pelo próprio Hitler foram frustradas pelo exército e por outras forças do Partido da Ordem, ou seja, que:

"O putsch abortado em 1923 tinha convencido Hitler de que qualquer ataque a
ordem existente estava fadado ao fracasso. Nem o Governo nem o Exército foram
pegos desprevenidos em 1923; as defesas das instituições democráticas, incluindo
os sindicatos, se mostraram fortes o suficiente para derrotar um putsch, apesar de
todos os problemas internos e externos da República. Acima de tudo, o respeito
pela autoridade e pela burocracia, que foram um dos problemas fundamentais da

${ }^{199}$ Idem, p. 101. tradução livre de "tradionalism can only become conservatism in a society in which change occurs through the medium of class conflict - in a class society. This is the sociological background of modern conservatism".

${ }^{200}$ GAY, Peter, Op. cit, 1978, p. 180. 
República de Weimar, se provaram um obstáculo considerável a todas as tentativas de golpe" ${ }^{\text {201. }}$.

Hitler percebera que a idéia de legalidade, mesmo em um momento de marcada falta de autoridade do regime deveria ser uma de suas bandeiras, e o caminho do poder deveria ser traçado através da disputa eleitoral e parlamentar. Essa tendência evolucionária seria o que Bracher chama de revolução legal, diz Bracher:

“O slogan revolução legal é uma chave para entender o caráter e o desenvolvimento da ascensão ao Poder dos Nacional-Socialistas. Os propagandistas, políticos e constitucionalistas do Nacional Socialismo sempre enfatizaram o fato de que, embora a tomada do poder por Hitler tenha significado o início de uma revolução que iria afetar profundamente todos os aspectos da vida, foi um processo completamente legal e de acordo com a Constituição. O conceito paradoxal de 'revolução legal' ligava artificialmente dois axiomas contraditórios do comportamento e da ação política. (...) Ao examinar os componentes específicos desse processo político, encontramos que essa estratégia desempenhou um papel decisivo na ascensão deste novo tipo de poder totalitário, com sua aura da legalidade e da efetividade, tornou muito difícil toda a forma resistência legal, política e mesmo intelectual, na opinião de muitos, tronou quase impossível”202.

O próprio Hitler, dois dias após as eleições de setembro de 1930, discursou a respeito da participação parlamentar do partido, que havia saltado de 12 para 107 assentos no Reichstag neste ultimo pleito, tornando-se o segundo maior partido no parlamento alemão. Hitler deixa claro em seu discurso qual o papel e o significado do

\footnotetext{
${ }^{201}$ BRACHER, Karl Dietrich, The German Dictatorship, Londres, Penguin Books, 1978. p. 244-245. tradução livre de "The abortive putsch of 1923 had convinced Hitler that any attack on the existing order was doomed. Neither the Government nor the Army had been caught napping in 1923; the defenses of the democratic parties, including the unions, proved strong enough to withstand a putsch, despite all the internal and external problems of the Republic. Above all, the very respect for authority and bureaucracy which so strained the fabric of the Weimar Republic at the same time proved a considerable obstacle to all coup attempts"

${ }^{202}$ BRACHER, Karl Dietrich, Op. cit, 1978, p. 244. tradução livre de "The slogan of legal revolution offers the key to the character and development of the National Socialist Power seizure. National Socialist propagandists, politicians, and constitutional experts all long emphasized that although Hitler's take over was the beginning of a revolution that would profoundly affect all aspects of life, it was a completely legal, constitutional process. The paradoxical concept of a 'legal revolution' artificially linked two contradictory axioms of political action and behavior. (...) In examining specific components of the political process, we find that this tactic played a decisive role in surrounding this new type of totalitarian power seizure with its seductive aura of effectiveness and made all legal, political, or even intellectual resistance so difficult, and, in the opinion of many, well-nigh impossible"
} 
jogo eleitoral e do respeito à instituição da república, embora não veja no sistema parlamentar a finalidade política do partido, diz ele:

\begin{abstract}
"Se a nossa Ação emprega hoje, entre outras armas, a do parlamento, isto não quer dizer que os partidos parlamentares só existem para fins parlamentares. Para nós, o parlamento não é um fim em si mesmo, mas apenas um meio para obter um fim... não somos, em princípio, um partido parlamentar: isso seria contradizer toda nossa ideologia. Somos um partido parlamentar por que a isso nos compele a constituição. A constituição nos obriga a empregar esse meio. Não nos obriga a visar tal ou tal fim, apenas prescreve uma forma, um método. E, repito-o, nós seguimos esse caminho legalmente, de acordo com a Constituição: pelo caminho nela traçado marchamos para a meta que nos propusemos”203.
\end{abstract}

E Hitler vai mais além ao afirmar que "Não é para obter cadeiras no parlamento que lutamos, mas conquistamos cadeiras no parlamento afim de que um dia possamos libertar o povo alemão"204 . Ao assumir o poder, através do ato aprovado pelo Reichstag em 23 de março de 1932, Hitler de fato abandonaria o jogo eleitoral e parlamentar, através da brecha concedida pelo artigo 48 da Constituição, ele passou a governar em regime de exceção suspendendo o parlamento e os direitos fundamentais, sepultando a democracia e a República (ver discurso de 23 de março de 1933 no anexo 8.4.)

Outro elemento que caracterizava o Nacional Socialismo como movimento novo era sua capacidade de se apropriar das novas tecnologias e da velocidade na propagação de informações. Enquanto o trem era ainda o principal meio de locomoção na Alemanha, Hitler viajava de avião durante as campanhas eleitorais, o que lhe possibilitava realizar um número muito maior de aparições nas diversas cidades alemãs do que qualquer um de seus oponentes. Também a propaganda cinematográfica, que seria fundamental nos anos após a derrocada de Weimar, no governo NacionalSocialista, é um bom exemplo da apropriação pelos Nacional-Socialistas da tecnologia.

\footnotetext{
${ }^{203}$ HITLER, Adolf, Op. cit., 1943, p. 80.

${ }^{204}$ Idem, 1943, p.81.
} 
Hitler, nos últimos anos de Weimar, identificava a Republica parlamentar apenas como fruto de destruição e desgraça da Alemanha. Isso fica claro em seu discurso de 1 de fevereiro de 1933, quando ele sugere que a democracia é o caos desagregador:

\begin{abstract}
"Mais de quatorze anos passaram desde o dia aziago em que o povo alemão, iludido por promessas de inimigos internos e externos, perdeu o contacto com a honra e a liberdade, perdendo tudo em conseqüência. Desde esse dia de traição, o Onipotente retirou as suas bênçãos entre nosso povo. A dissensão e o ódio desceram sobre nós. Com profunda amargura, milhões dos melhores homens e mulheres alemãs de todas as camadas da vida tem visto a unidade da nação a desaparecer, a dissolver-se numa confusão de opiniões pessoais e políticas, interesses econômicos e diferenças ideológicas" ${ }^{205}$.
\end{abstract}

Hitler continua, falando contra o Iluminismo e os adventos que dele surgiram: "Jamais recebemos a igualdade e fraternidade que nos foram prometidos, e perdemos além disso a nossa liberdade ${ }^{\text {206 }}$. E pregando sobre o espírito e a vontade do povo alemão, assuntos que levantavam a moral da população, e atravessando o povo com a idéia de grandeza que fora retirada da Alemanha após a derrota na Guerra e Versalhes.

Nos discursos contra a República de Weimar, ainda durante a república, Hitler procurava sempre identificar a República ao marxismo e ao comunismo, juntando ambos como inimigos comuns, indo além, dizendo que a República “que preparava o caminho para o marxismo, a democracia antinacional”207. Ele dizia próprio do comunismo tudo aquilo que era antinacionalista, que ia de encontro com os elementos fundamentais do nacionalismo alemão, a moralidade, a cultura, a honra, a fé, em um discurso Hitler disse:

"Este espírito destruidor e negativo não poupa nada do que é mais alto e valioso. A começar pela família, já minou os próprio fundamentos da moralidade e da fé e escarnece a cultura e comércio, da nação e da Pátria, da justiça e da honra.

\footnotetext{
${ }^{205}$ HITLER, Adolf, Op. cit., 1943, p. 116.

${ }^{206}$ Idem, 1943, p. 116.

${ }^{207}$ Ibidem, 1943, p. 178.
} 
Quatorze anos de marxismo arruinaram a Alemanha; um ano de bolchevismo a destruiria"208. $^{2}$.

Dessa maneira, Hitler negava não ao programa de cada um dos Partidos, o KPD e o SPD, de maneira pontual, mas desqualificava-os como inimigos do povo alemão. Após 1932, com a retomada da ação das SA e das SS, a luta nas ruas se intensificou, com um considerável aumento da violência. Os líderes comunistas passaram a ser perseguidos e as manifestações de rua dos comunistas impedidas pela violência dos grupos nazistas. Os sindicatos, em maioria sob controle da Social Democracia desde o estabelecimento da República, passaram a ter sua atividade controlada e suas manifestações reprimidas pelas SA e SS. Em um discurso para as SA e SS em 8 de abril de 1930, em Berlim, Hitler agradeceu à valentia de seus membros e mais uma vez expos seu juízo a respeito da ineficácia da democracia e a necessidade da autoridade:

\footnotetext{
"Posso dizer com orgulho, companheiros da SA e da SS, que se todo o povo alemão fosse tocado pelo espírito de que estamos e estais possuídos, a Alemanha seria indestrutível. (...) Adotamos, também, o princípio de chefia, a concepção de autoridade. Foi esse um pesado sacrifício no momento em que todo o povo corria atrás da ilusão de democracia e parlamentarismo, em que milhões de pessoas que a maioria era a fonte de uma decisão correta. Foi nesse tempo que nós começamos resolutamente a construir uma organização na qual não havia um ditador mas dez mil"209.
}

John Lucaks avalia muito bem a importância desse ataque recorrente de Hitler contra a República e seus defensores, além, é claro, dos marxistas: Hitler sabia que a desde que a República nascera esteve cercada por aqueles que não a queriam, ou que simplesmente a aceitavam, não havia uma coesão social em torno da instituição da República $^{210}$. Junto a República, Hitler colocava os comunistas, que de fato estiveram junto a Social Democracia até a eclosão da Grande Guerra, não parecia, aos olhos

\footnotetext{
${ }^{208}$ Ibidem, 1943, p. 117.

${ }^{209}$ Ibidem, 1943, p. 129.

${ }^{210}$ LUKACS, John, O Hitler da História, Rio de Janeiro, Jorge Zahar Editor, 1998, p. 68.
} 
daqueles que não tinham simpatia à republica de todo errado colocar Comunistas e Social Democratas no mesmo bonde. Sobre esse lado conservador e o porquê do sucesso desse argumento dentre a população alemã, diz Lukacs:

"Quaisquer que fossem as raízes mais profundas do nacionalismo, do conservantismo, do antimarxismo e do anti-semitismo na mente dessas pessoas, as convicções que tinham na época eram resultado da experiência e de suas reações contra os revolucionários esquerdistas em Munique e em outras cidades da Alemanha em 1918-19,"211.

Por fim, Lukacs conclui de forma convincente: ao contrário dos demais partidos, ao misturar promessas para as classes trabalhadoras, garantias de ordem social e respeito à disciplina, promessas de modernização do país, e mais do que tudo, se colocando contra o Tratado Versalhes e contra a Republica de Weimar, Hitler conseguiu que sua popularidade estivesse distribuída em diversas camadas da população, e não apenas em uma classe específica. Muito embora ele tivesse na base de sua sustentação o apoio dos trabalhadores alemães, diz Lukacs:

\footnotetext{
“A novidade do Partido Nacional-Socialista não residia apenas em sua organização e propaganda. Ao contrário de todos os demais partidos na República de Weimar, os nacionais-socialistas formavam um verdadeiro partido do povo, um Volkspartei, uma vez que conquistou adeptos em todas as classes, entre todos os elementos da sociedade alemã”.
}

${ }^{211}$ LUKACS, John, Op. cit., 1998, p. 68. 


\title{
6. Considerações Finais
}

\begin{abstract}
“O ideal de Weimar era ao mesmo tempo antigo e novo. A impressionante mistura de cinismo e confiança, a busca por novidade e por raízes - a solene irreverência dos anos vinte, eram frutos de guerra, revolução e democracia, mas os elementos que lhe deram corpo vieram de ambos os passados, o distante e o recente, recordado e vivido pela nova geração"212.
\end{abstract}

“... Antes e depois de os nazistas terem tomado o poder, umas das correntes importantes dentro da ideologia conservadora e subseqüentemente nazista era aquela que buscava conciliar idéias antimodernistas, românticas e irracionalistas existentes no nacionalismo alemão com a mais óbvia manifestação da racionalidade de meios e fins, isto é, com a tecnologia moderna"213.

Em artigo publicado em 6 de junho de 1936 no Volkische Beobachter, Adolf Hitler definiu-se como o "o mais conservador revolucionário do mundo" ${ }^{214}$. Tendo a noção da novidade do fenômeno do Nacional-Socialismo, Hitler evitou rótulos que pudessem remeter a outros movimentos e períodos na história. Mas ao unir Conservação e Revolução, conceitos inconciliáveis na genealogia do pensamento ocidental, Hitler tinha em mente toda a inovação política que significava o movimento Nacional Socialista - desde seu surgimento, sua luta na arena partidária da República de Weimar, até sua ascensão ao poder. Nas palavras de John Lukacs:

\begin{abstract}
"Poucas coisas são tão equivocadas quanto a tendência de encarar Hitler como um reacionário. Ele era a própria antítese disso. (...) Naquele momento da história da humanidade, Hitler representava era a eficiência brutal, e de modo algum ilógica, da força mecanicamente organizada e com apoio popular."215
\end{abstract}

Para além de todo o seu substrato ideológico, a gênese do movimento nacionalsocialista estava ligada diretamente a gênese da República de Weimar. Um período marcado pela tentativa de construção de um Estado que substituísse aquele que fora

\footnotetext{
${ }^{212}$ Idem, 1978, p. 16.

${ }^{213}$ HERF, Jeffrey. Op. cit, 1993, p. 13.

${ }^{214}$ HITLER, Adolf, 1936 apud BOBBIO, Norberto. Direita e Esquerda: Razões e significados de uma distinção política, São Paulo, UNESP, 2001, p. 69

${ }^{215}$ LUKACS, John, Op cit, p. 21.
} 
destruído após a Grande Guerra com a derrota militar e a fuga do imperador - símbolo do êxito da unificação. Se, por um lado, a reconstrução política e normativa aparecia como necessária: o que se realizou com a promulgação da Carta Constitucional da República de Weimar; por outro, havia grandes esforços para discutir o papel do indivíduo no processo iniciado em fins de 1918.

A Constituição de Weimar, em grande medida obra do jurista Hugo Preuss, foi aprovada na Assembléia Constituinte por uma coalizão sustentada por uma maioria Social-Democrata (37,86\% dos votos) combinada ao Centro Católico $(19,67 \%)$ e ao partido Democrático $(18,56 \%)$. Na constituição se celebrava uma série de conquistas sociais, na primeira constituição de caráter fundamentalmente programático da história do Estado de Direito. Celebrava-se também um importante arcabouço legal em torno dos Direitos Fundamentais. Mas, além disso, instituía um importante mecanismo, visando a governabilidade do executivo frente a um possível impasse entre executivo e legislativo, que era o artigo 48. Esse artigo, conforme a argumentação de Carl Schmitt, abria uma brecha autoritária na constituição, que foi usada, como levantado no capitulo 4, 250 vezes, das quais 130 nos 4 anos iniciais da República. A possibilidade do uso deste estado de exceção como ferramenta de governabilidade abria o precedente autoritário ao chefe do executivo. Foi dessa maneira que Hitler, em 23 de março de 1933, recebeu plenos poderes do Reichstag, instalando um estado de exceção de 12 anos.

Por outro lado, na nascente república, as palavras Völk, Kultur e Zivilisation, caracterizavam no plano da linguagem a ideologia dos movimentos políticos, literários e filosóficos do século XIX - o romantismo, o anti-iluminismo ou anti-racionalismo. No centro das discussões a respeito do individuo em Weimar estava também a revisão destes conceitos. Sobre esse momento de mudança após o fim da Grande Guerra, disse o 
professor da Bauhaus Walter Gropius: "Isto é mais do que a perda de uma guerra. Um mundo chegou ao fim. Teremos que buscar uma solução radical para nossos problemas ${ }^{216}$. Nesse sentido, um estudioso do processo de Weimar acrescentou:

\footnotetext{
“...para os participantes da República, as perguntas mais insistentes giravam em torno da necessidade de renovação do homem, perguntas tornadas mais urgentes e praticamente insolúveis pelo desaparecimento de Deus, a ameaça da máquina, a estupidez incurável das classes superiores e o filistinismo desamparado de burguesia” $^{\text {217. }}$.
}

Com a proclamação da República, e apesar do acordo entre a Social-Democracia e o que Versalhes permitia que fosse o Exército, os grupos sociais e políticos afastados do centro de decisão desde a vitória conservadora em 1848 esperavam ver realizados seus anseios e esperanças. Entre os grupos destacavam-se o SPD, os Liberais e, temendo a repetição da Kulturkampf do tempo de Bismarck, o Centro Católico. Estes partidos tinham presença no parlamento já nos tempos do Império, mas estavam afastados do poder executivo, que centralizava grande parte dos poderes.

A nova bandeira da Alemanha, com as cores ouro, vermelho e preto, mas sem o brasão imperial, era a bandeira proposta pelos revolucionários derrotados em 1848. Ao longo do século XIX, parcelas da burguesia e as classes médias e baixas adotaram uma posição apolítica em relação ao Império. O exemplo mais flagrante desse comportamento encontra-se na elite intelectual e artística que se desenvolveu a margem da arte modelar romântica e neo-romântica do Império. A urgência das questões colocadas pela Guerra e pelo Tratado de Versalhes, trouxe esses grupos de volta à arena política. A esse respeito, Peter Gay observa:

\footnotetext{
${ }^{216}$ GAY, Peter, Op cit, 1978, p. 22.

${ }^{217}$ Idem, 1978, p. 20.
} 
"A guerra deu-lhe um elenco político e um tom estridente e encilhou-a [a intelligentsia] com uma querela mortal; a revolução deu-lhe oportunidades sem precedentes. Mas a República pouco criou, apenas liberou aquilo que já existia”218.

Berlim fervia com a agitação popular em Berlim, que se seguira ao anúncio da abdicação do Kaiser feito pelo social-democrata Friedrich Ebert e pela proclamação da República, feita pelo também social-democrata Philipp Scheidemann. Ainda antes da queda do Kaiser, Kurt Eisner, socialista independente, proclamou na Baviera uma república socialista, nomeando-se Primeiro Ministro; logo após a instalação da República, foi a vez dos Espartaquistas comandados por Rosa Luxembourg e Karl Liebknecht tentarem tomar o poder.

Com o pacto entre a Social-Democracia e os militares, representados respectivamente por Ebert e o general Groener, sucessor de Ludendorff no comando do Exército, foi garantido o estabelecimento da República, bem como a manutenção da ordem pública. O desmantelamento das tentativas revolucionárias empreendidas por Luxembourg e Liebknecht em Berlim, e por Eisner na Baviera, foi comandado pelo social-democrata Noske, com o auxílio das forças de segurança do Exército e com ativa participação de grupos de defesa paramilitares formados por ex-oficiais, desempregados e jovens $^{219}$. Esses grupos, os Freikorps agiam de maneira brutal e violenta contra tudo aquilo que julgassem antipatriótico, fosse de maneira independente fosse auxiliando as forças armadas regulares. Segundo descreve E. J. Gumbel,

"Finalmente, os grupos militares ilegais incluíam um conjunto de organizações terroristas fanáticas, pequenas em tamanho, mas importantes em seu trabalho de assassinatos políticos, eliminando primeiro os líderes da Revolução, depois os republicanos proeminentes e, por fim, os inimigos do rearmamento ilegal,220.

\footnotetext{
${ }^{218}$ Ibidem, 1978, p. 19.

${ }^{219}$ Ibidem, 1978, p. 168.

${ }^{220}$ GUMBEL, E. J., "Disarmament and Clandestine Rearmament under the Weimar Republic” in MELMAN, Seymour, Op. cit, 1958. p. 203-219. tradução livre de "Finally, the illegal military groups included an array of fanatic terroristic organizations, small in size, but important for their work of political assassination in eliminating first the leaders of the Revolution, then prominent Republicans, and finally the enemies of the illegal rearmament"
} 
Estava no cerne do imaginário da população, a idéia de que Guerra fora perdida em virtude de uma traição cometida no interior do país. Para os que pensavam assim, a prova era que o Exército combatera 4 anos em território estrangeiro, além das fronteiras do Estado alemão, sem que o povo pudesse em sua plenitude defender sua honra e lutar até o fim definitivo. Em suas memórias, o historiador Felix Gilbert relembra que o clima dentre os alemães durante a Guerra era de relativa tranqüilidade, à exceção dos momentos em que houve problemas no abastecimento de Berlim, já na segundo metade da Guerra. Sobre essa relativa tranqüilidade, ele aponta:

\footnotetext{
"Na Primeira Guerra Mundial, no entanto, a vida dentro da Alemanha continuou basicamente o seu curso; a guerra não trouxe nenhuma mistura de classes sociais, nenhum reagrupamento na hierarquia social. Assim, após a Primeira Guerra Mundial, as forças que tinham dominado Alemanha no período pré-guerra ainda eram fortes, e fizeram sentir o seu peso na política externa e interna,221.
}

A combinação entre esse clima de relativa tranqüilidade sentida pelos alemães durante os primeiros 3 anos da Guerra, combinado com a manutenção de grande parte dos grupos políticos no cenário da República nascente, tornava ainda mais incompreensível a derrota, para o cidadão comum. Foi essa sensação de incompreensão da derrota, justificável somente através de uma traição, que fez com que a lenda da punhalada pelas costas tivesse penetração e popularidade. Segundo Peter Gay, “a lenda de um Exército alemão imbatível apunhalado pelas costas, em seu território, pelos

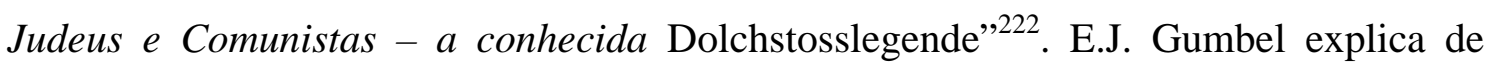
maneira ainda mais clara,

\footnotetext{
${ }^{221}$ GILBERT, Felix, Op. cit, 1988, p. 31, trad livre de "In the First World War, however, life inside the Germany basically continued on its previous course; the war brought about no intermingling of social classes, no regrouping of the social hierarchy. Thus, after the First World War the forces that had dominated Germany in the prewar period were still strong, and they made their weight felt in the foreign and domestic policy"

${ }^{222}$ GAY, Peter, Op cit, 1978, p. 33
} 
"A derrota, a disseminação de um horror à guerra e ao derramamento de sangue, tinha privado o Exército de sua respeitabilidade. Agora, como por definição todo Exército Nacional é invencível e sempre que a derrota é evidente ela deve ser invalidada. Freqüentemente, traidores são apontados no Governo e no Exército. Dessa vez fora a Pátria que traíra o Exército. Assim, a lenda da 'punhalada pelas costas' foi inventada"223.

\title{
A lenda da punhalada pelas costas esteve presente de maneira definitiva no
} imaginário do Alemão nos primeiros anos da República. O simbolismo da traição ia além de qualquer evidência concreta de traição. O Exército e os aristocratas que permaneceram na vida política após a Guerra não realizaram qualquer esforço para desmentir a provável traição. Uma medida da penetração da lenda pode ser vista no filme clássico do cinema expressionista alemão, “Siegfried” (1924), de Fritz Lang. No filme, dedicado “ao povo alemão”, está contada a história do personagem mítico alemão que é traído e apunhalado pelas costas. O próprio Guilherme II em suas memórias, aceita e usa a tese de que a Alemanha fora apunhalada pelas costas e traída na Guerra, diz ele:

\begin{abstract}
"Com certeza a bravura e o heroísmo da nação alemão merecia um futuro melhor do que cair vítima do punhal que traiçoeiramente a esfaqueou pelas costas; parece ser o destino do alemão que a Alemanha sempre seja derrotada por alemães. Recentemente eu li as infortunas mas não totalmente injustificadas palavras: 'na Alemanha cada Siegfried tem Hödur atrás de si”224.
\end{abstract}

${ }^{223}$ GUMBEL, E. J., "Disarmament and Clandestine Rearmament under the Weimar Republic” in MELMAN, Seymour, Op. cit. , 1958. p. 203-219. tradução livre de "Defeat, and widespread hatred of war and bloodshed, had deprived the army of its respectability. Now, by definition, every national army is invincible and, since the defeat was evident, it had to be disproved. Different fictions are available for such purposes. Usually, traitors are found in the government and in the army. This time, it was the Fatherland which had betrayed the army. Thus, the legend of the "stab-in-the-back" was invented". ${ }^{224}$ WILHELM II, The Kaiser's Memoirs, New York, Harper \& Brothers, 1922, p. 260, trad livre de "Surely the heroic bravery of the German nation deserved a better fate than to fall a victim to the dagger that treacherously stabbed it from behind; it seems to be the German destiny that German shall always be defeated by Germans. Recently I read the unfortunately not entirely unjustified words: 'In Germany every Siegfried has Hödur* behind him”. [*Hödur é o deus do inverno e das sombras, é conhecido por ter matado seu irmão]. 
Somado ao sentimento de traição e derrota, havia ainda a inflação, a desordem social e a descrença generalizada na República, que cooperavam para a instabilidade institucional do regime de Weimar. Uma mistura de efervescência e caos era a melhor descrição do clima na Alemanha e, em especial, Berlim²25. Dessa maneira como descreve Peter Gay, os primeiros momentos da República foram marcados pelas dificuldades, políticas, econômicas e sociais, que dificultavam a tarefa de organização do Estado e de tranqüilizar a sociedade:

\begin{abstract}
"Os primeiro quatro anos da República foram de crise quase ininterrupta, uma época verdadeiramente de distúrbios. A guerra civil sangrenta, o ressurgimento dos militares como um fator político, o insucesso em desacreditar a aliança aristocrataindustrial que havia dominado o Império, a freqüência dos assassinatos políticos e a impunidade dos assassinatos políticos, a imposição do tratado de Versalhes, o Putsch Kapp e outras tentativas de subversão interna, a ocupação do Ruhr pela França, a inflação astronômica - todos esses fatores davam novo alento aos monarquistas, aos militaristas fanáticos, aos anti-semitas e xenófobos de toda a espécie, a industrialistas a princípio atemorizados pelo espectro da socialização e depois desdenhosos desses socialistas que não socializavam e ajudavam a fazer com que a República aparecesse como uma fraude ou uma farsa”226.
\end{abstract}

Após os primeiros 4 anos de completa instabilidade política, a República entrou em seu período menos tumultuado. Observando uma prosperidade econômica relativa, advinda do sucesso do plano de estabilização operado por H. Schacht, e uma relativa tranqüilidade no processo político e legislativo. O Partido Comunista (KPD) havia aceitado que sua participação deveria ocorrer na esfera eleitoral, após as frustradas tentativas de levante nos anos de 1919, 1921 e 1923. Do outro lado, após 1924 os movimentos contra a República, e mesmo os Freikorps perderam a força dos primeiros anos. Até a cristalização de todos esses grupos em torno do Partido Nacional-Socialista, o que iria ocorrer a partir de 1928 e, com maior clareza, no pleito para o Reichstag de setembro de 1930, quando o partido cresceu de 12 para 107 cadeiras no parlamento.

\footnotetext{
${ }^{225}$ De acordo com Peter Gay, a República fora fundada em Weimar pois era consenso que Berlim não era suficientemente segura, naquele novembro de 1918. Ver GAY, Peter, Op cit, 1978, p. 167-169

${ }^{226}$ GAY, Peter, Op cit. 1978, p. 24.
} 
Com a crise de 1929, a Alemanha enfrentou um novo período de dificuldades econômicas, embora sem que houvesse a repetição da inflação de 1923, marcada por uma retração na demanda e por um processo de deflação, motivados pela restrição ao crédito e aumento dos juros. Nas eleições de 1930, foi possível observar uma polarização entre grupos que, embora jogassem o jogo eleitoral e Parlamentar da República, não tinham no modelo republicano sua finalidade política. De um lado o Nacional-Socialismo alcançava as 107 cadeiras no parlamento; de outro os comunistas (KPD) saltavam de 54 para 77 cadeiras, enquanto os grupos que sustentavam a República tinham uma pequena retração em suas posições no parlamento no pleito de 1930. Esse resultado sinalizou para o sucesso da radicalização do discurso antirepublicano, diante da falência do modelo liberal por toda Europa.

Nesse sentido, registrou-se um aumento nas manifestações públicas dos partidos políticos. Destaca-se ainda, as táticas paramilitares usadas pelos grupos SA e SS, que operavam nas ruas na defesa dos interesses do Partido Nacional-Socialista, do qual eram membros. Essas organizações promoviam a perseguição e o conflito violento contra as manifestações e partidários do KDP e da Social Democracia (SPD). Do outro lado, KDP e SPD, tratavam-se como inimigos prioritários, revivendo a disputa interna do partido que se exacerbara durante a primeira Guerra. Combateram-se à exaustão. O não estabelecimento de uma frente conjunta entre social-democratas e comunistas, fenômeno que só ocorreria em 1935, foi um facilitador importante para a ascensão de Hitler e do Nacional-Socialismo: em novembro de 1932, SPD e KPD somaram aproximadamente 1,8 milhão de votos a mais do que o NSDAP, e a despeito disso, quatro meses depois, Hitler ascendia ao poder de modo definitivo, pondo um fim à primeira experiência democrática na Alemanha. 
A derrota final da República foi marcada pela capitulação de grupos sociais que, desde a queda do Kaiser, estiveram apoiando a República, para o Nacional-Socialismo. Esses grupos, cuja defesa da república se caracterizava menos por um principio ideológico, do que por um princípio de sobrevivência frente a ameaça da Revolução comunista, decidiram aceita Hitler, e empossá-lo em busca de uma alternativa que estabelecesse um modelo de autoridade e sustentação ao governo do debilitado Hindenburg. O golpe foi fatal para a República: na votação do ato que lhe concedia plenos poderes invocando o artigo 48 da Constituição, em 23 de marco de 1933, Hitler obteve o apoio do Centro Católico, que combinado ao apoio do DNVP e à votação de seu próprio partido somavam mais de 63\% dos votos para o Reichstag, sem contar os partidos menores. Dessa maneira ele atingiu condições de aprovar qualquer medida no Parlamento, colocando assim um ponto final na República.

Mas as perguntas giram sempre em torno de, por que a nação mais educada do mundo, com uma tradição filosófica e artística extensa, pode apoiar e colocar Hitler no poder? Os impactos posteriores para a história do mundo contemporâneo são de conhecimento amplo: guerra total e holocausto, dentre outros.

Cabe apontar aqui, como a idéia que Hitler encarnava era um misto de novidade e respeito ao passado, em conformidade com o analisado no quinto capítulo. Ele representava uma novidade que, ao mesmo tempo, rompia com a República, e com toda a simbologia carregada pela república: Versalhes, a derrota na Guerra e a proibição do exército e propunha um novo regime, sem romper, no entanto, com os elementos fundamentais do nacionalismo alemão, que se formara após a unificação. Esse respeito à uma história espiritual da Alemanha, fazia com que sua novidade pudesse atrair até os mais conservadores nacionalistas e, ao mesmo tempo, estabelecer sua sustentação popular junto à classe trabalhadora a quem defendia contra a incerteza da revolução, e a 
quem prometia desenvolvimento econômico e recuperação dos níveis de emprego de antes da crise de 1929.

Essa combinação de elementos em seu discurso, que Lukacs define como revolucionário, e Herf define como Modernismo Reacionário, unindo tradição e uma idéia de futuro, o respeito aos códigos morais militares de origem prussiana, e uma crença nas inovações tecnológicas, anti-iluminismo e um governos centralizado com o Estado presente na sociedade e na economia, fez com que a incompreensão pairasse diante de seus inimigos: o marxismo reluta em enxergar Hitler apenas como um representante do grande capital, como mais um Reacionário. Já para o povo alemão, o programa Nacional Socialistas oferecia uma segurança envolvida em uma sedutora novidade que prometia realizar aquilo que a Guerra de 1914 e que os freikorps haviam tentado, a regeneração da alma alemã, do espírito de comunidade do povo.

Por fim, Hitler, opôs-se, não a Comunistas ou a Social-Democratas, mas a todos eles juntos, e também a Republica, como se fossem um conjunto único representando a desordem e a indisciplina que acometera a Alemanha após a traição e a derrota na Grande Guerra. Hitler, personificava a ordem para o alemão: a combinação de tudo aquilo que poderia salvar a alma alemã contra a "bolchevização internacional”, oferecendo não uma opção a mais no espectro político democrático, mas reduzindo aos olhos do alemão, as opções entre a ordem, representada por ele próprio, e a desordem. 


\section{Referências:}

AGAMBEM, Giorgio, Estado de Exceção, São Paulo, Boitempo, 2004.

ALMEIDA, Ângela Mendes, A República de Weimar e a Ascensão do Nazismo - $3^{\mathrm{a}}$ ed, São Paulo, Brasiliense, 1999.

ANGELL, Norman, A Grande Ilusão, Brasília, Editora Universidade de Brasília, 2002.

ARENDT, Hannah, Origens do Totalitarismo - anti-semitismo, imperialismo, totalitarismo, São Paulo, Companhia das Letras, 2004.

_, Homens em Tempos Sombrios, São Paulo, Companhia das Letras, 1987.

, Compreender: Formação, exílio e totalitarismo, São Paulo, Companhia das

Letras, 2008.

, Sobre a Revolução, Lisboa, Relógio d’Água, 2001.

, A Condição Humana, Rio de Janeiro, Forense, 2008.

, Sobre a Violência, Rio de Janeiro, Relume Dumará, 2001.

ARGAN, Giulio Carlo, El arte moderno, Valencia, Fernando Torres, 1976

ARISTÓTELES, Política apud Vários Autores, The Great Ideas, Londres, Encyclopaedia Britannica, 1961.

BARR, Alfred H., Hitler el les neuf muses, Paris, L’Échoppe, 2005.

BARTH, Hans, The Idea of Order, Holanda, D. Reidel Publishing Company, 1960.

BEAUD, Michel, História do Capitalismo: de 1500 até os nossos dias, Brasília, Brasiliense, 1989

BEBEL, August, Aus meinem Leben, Part 2, Stuttgart, 1911.

BERNSTEIN, Eduard, Socialismo Evolucionário, Rio de Janeiro, Jorge Zahar, 1997.

BERLIN, Isaiah, A Força das Idéias, São Paulo, Cia. das Letras, 2005. 
BOBBIO, Norberto; MATTEUCCI, Nicola e PASQUINO, Gianfranco, Dicionário de Política- 5a Ed, Brasília, Editora Universidade de Brasília, 2000.

BOBBIO, Norberto, Direita e Esquerda: Razões e significados de uma distinção política, São Paulo, UNESP, 2001.

BRACHER, Karl Dietrich, The German Dictatorship, Londres, Penguin Books, 1978.

BRECHT, Bertolt, Teatro- 6 vols, Rio de Janeiro, Civilização Brasileira, 1976.

BRENER, Jayme, 1929: A crise que mudou o mundo, São Paulo, Ática, 1996

BRY, Gerhard, Wages in Germany 1871-1945, Princeton, 1960.

BULLOCK, Alan, Hitler and Stalin, Nova Iorque, Alfred A. Knopf, 1991.

BURKE, Edmund, Textos Politicos, México, Fondo de Cultura Econômica, 1996. , Reflexões sobre a Revolução em França, 2a . Ed, Brasília, UNB, 1997

CANETTI, Elias, Massa e Poder, São Paulo, Cia das Letras, 1995

CARR, Edward Hallet, The Twenty Years' Crisis, Nova Iorque, Palgrave MacMillan, 2001.

CASSIRER, Ernst, O Mito do Estado, São Paulo, Codex, 2003.

CALWER, Richard, Monatliche Ubersichten uber Lebensmittelpreise, Berlim, 1913.

CHURCHILL, Winton S, Memórias da Segunda Guerra Mundial- $2^{a}$ Ed, Rio de Janeiro, Nova Fronteira, 1995.

CLAUDIN, Fernando, La crisis del movimento comunista, Paris, Ruedo Iberico, 1970.

DEUTSCHER, Isaac, Trostski - O Profeta Armado, Rio de Janeiro, Civilização Brasileira, 1968.

, Trostski - O Profeta Desarmado, Rio de Janeiro, Civilização Brasileira, 1968.

, Trostski - O Profeta Banido, Rio de Janeiro, Civilização Brasileira, 1968. 
DOBB, Maurice, A Evolução do Capitalismo- $3^{a}$ Ed, Rio De Janeiro, Zahar Editores, 1973.

DRESLER, Adolf, German Art and Degenerate “Art”, USA, Preuss, 2008.

EKSTEINS, Modris, A Sagração da Primavera- $2^{a}$ Ed, Rio de Janeiro, Rocco, 1991.

ELIAS, Norbert, Os Alemães, Rio de Janeiro, Jorge Zahar Editor, 1997.

ENGELS, Friedrich, Do Socialismo Utópico ao Socialismo Científico, Lisboa, Editorial Estampa, 1974.

A Origem da Família da Propriedade e do Estado- $3^{\circ}$ Ed, Lisboa, Editorial

Presença, 1976.

, Revolução e Contra-Revolução na Alemanha, Lisboa, Progresso, 1982.

. A Guerra dos Camponeses Alemães, Lisboa, Progresso, 1982

EVANS, Richard S., The Coming of the Third Reich, London, Penguin Books, 2003.

., “Ascenso y triunfo del nazismo en Alemania” en CABRERA, Mercedes,

Europa em crisis 1919.1939, Madrid, Pablo Iglesias, 199

FERREIRA, Oliveiros S., Nossa América: Indoamérica, São Paulo, Editora da Universidade de São Paulo, 1971.

Os 45 Cavaleiros Húngaros, Brasília, Editora Universidade de Brasília, 1986.

FEST, Joachim, Hitler, Nova Iorque, Harcourt, 2002.

FIGES, Orlando, A People’s Tragedies, Inglaterra, Penguin, 1998.

GAULLE, Charles, Memórias de Guerra, Madri, La Esfera, 2005.

GAY, Peter, A Cultura de Weimar, Rio de Janeiro, Paz e Terra, 1978.

GILBERT, Felix, A European Past, New York, W. W. Norton \& Company, 1988

GOLDENSOHN, Leon, As Entrevistas de Nuremberg, São Paulo, Companhia das Letras, 2005. 
GOLDHAGEN, Daniel Jonah, Os Carrascos Voluntários de Hitler, São Paulo, Cia. das Letras, 1997.

GRAMSCI, Antonio, Maquiavel, A Política e o Estado Moderno $-2^{a}$ ed, Rio de Janeiro, Civilização Brasileira, 1976.

, Os Intelectuais e a Organização da Cultura $-2^{a}$ ed, Rio de Janeiro, Civilização Brasileira, 1987.

GUINSBURG, Jaco, O Expressionismo, São Paulo, Perspectiva, 2002.

GUMBEL, E. J., "Disarmament and Clandestine Rearmament under the Weimar Republic” in MELMAN, Seymour, Inspection for Disarmament. Columbia, University Press, 1958. p. 203-219.

HERF, Jeffrey, O Modernismo Reacionário, São Paulo, Ensaio, 1993.

HITLER, Adolf, Minha Luta, Porto Alegre, Livraria Globo, 1940.

, Minha Nova Ordem, Porto Alegre, Meridiano, 1943.

HOBSBAWM, Eric, A Era dos Extremos - $2^{a}$ ed,, São Paulo, Companhia das Letras, 1995.

, Sobre História, São Paulo, Companhia das Letras, 1998.

, Revolucionários - 2ª ed, Rio de Janeiro, Paz e Terra, 1985.

, A Era dos Impérios - 5ª ed, Rio de Janeiro, Paz e Terra, 1998.

, A Era do Capital - 5 ${ }^{a}$ ed, Rio de Janeiro, Paz e Terra, 2000.

, A Era das Revoluções- $12^{a}$ ed, Rio de Janeiro, Paz e Terra, 2000.

, O Novo Século, São Paulo, Cia das Letras, 2000.

, A História do Marxismo - O Marxismo na Época da Terceira

Internacional: Problemas da Cultura e da Ideologia - $2^{a}$ ed, Rio de Janeiro, Paz e Terra, 1989. 
A História do Marxismo - O Marxismo na Época da Terceira

Internacional: da Internacional Comunista de 1919 às Frentes Populares - $2^{a}$ ed, Rio de Janeiro, Paz e Terra, 1988.

, Nações e Nacionalismo desde 1780-2ª Ed, São Paulo, Paz e Terra, 1998.

HOBSBAWM, Eric J. e RANGER, Terence, A Invenção das Tradições - $3^{a}$ Ed, São Paulo, Paz e Terra, 2002.

HORKHEIMER, Max e ADORNO, Theodor W, Dialética do Esclarecimento, Rio de Janeiro, Jorge Zahar, 1985.

HORKHEIMER, Max. Eclipse da Razão, São Paulo, Centauro, 2007.

HUICI, Adrián, Estrategias de la persuasión: mito y propaganda política, Sevilla, Alfar, 1996.

JOHNSON, Paul, Modern Times, Inglaterra, Harper Perennial Modern Classics, 2001.

KAUTSKY, Karl, Selected political writings, Londres, Macmillan, 1983.

KEEGAN, John, Uma História da Guerra, São Paulo, Companhia das Letras, 1995. , The First World War, New York, Vintage Books, 1999.

KELSEN, Hans, Teoria pura do direito, 6. Ed., São Paulo, Martins Fontes, 2000.

KERSHAW, Ian, Hitler: 1889-1936, Barcelona, Península, 1999.

KEYNES, John Maynard, The Economic Consequences of the Peace, Londres, Kessinger Publishing, 2005.

KISSINGER, Henry, A Diplomacia das Grandes Potencias- $3^{a}$ Ed, Rio de Janeiro, Francisco Alves, 2001.

LENIN, Vladimir Ilich, Política, São Paulo, Abril Cultural, 1978.

, Esquerdismo, doença infantil do comunismo $-6^{a}$ ed, São Paulo, Global, 1989.

, Obras escolhidas-vol. 1, São Paulo, Alfa-Omega, 1979. 
LOUREIRO, Isabel, A Revolução Alemã, São Paulo, UNESP, 2005.

LUXEMBOURG, Rosa, A Acumulação do Capital, São Paulo, Abril Cultural, 1984. , Anticrítica, São Paulo, Abril Cultural, 1984. , Reforma ou Revolução, São Paulo, Expressão Popular, 1999

LUKACS, John, Cinco Dias em Londres, Rio de Janeiro, Jorge Zahar Editor, 2001. , O Hitler da História, Rio de Janeiro, Jorge Zahar Editor, 1998.

, O Duelo: Churchill X Hitler, Rio de Janeiro, Jorge Zahar Editor, 2002.

, O Fim de uma Era, Rio de Janeiro, Jorge Zahar Editor, 2005.

MACMILLAN, Margaret, Paz em Paris, Rio de Janeiro, Nova Fronteira, 2004.

MANN, Michael, Fascistas, Rio de Janeiro, Record, 2008.

MANN, Thomas, Os Bundenbrook, São Paulo, Círculo do Livro, 1979.

MANNHEIM, Karl, Essays on Sociology and social psychology, London, Routledge and Kegan Paul Ltd, 1959, p.79. , Sociologia da Cultura, São Paulo, Perspectiva, 2008.

MARCUSE, Herbert, Razão e Revolução- $2^{a}$ Ed. Rio de Janeiro, Paz e Terra, 1978. , Contra-Revolução e Revolta, Rio de Janeiro, Zahar, 1973.

MARK, Karl, O 18 Brumário de Louis Bonaparte, Coimbra, Oficinas Gráficas, 1971. , A Luta de classes em França de 1848 a 1850, Lisboa, Avante, 1997. ।

MARX, Karl e ENGELS, Friedrich, A Ideologia Alemã, São Paulo, Grigalbo, 1977. , Manifesto Comunista, São Paulo, Boitempo, 1998. , Textos - Vol. 1, São Paulo, Edições Sociais, 1977. , A Sagrada Família, Lisboa, Editorial Presença, 1974.

MEAD, Walter Russel, Special Providence: American Foreign Policy and How It Changed the World, Londres, Routledge, 2002.

METZGER, Rainer, Berlin: Lês années vingt, Paris, Hazan, 2006 
MITCHELL, B. R., European Historical Statistics, 1750-1975, Nova Iorque: Facts on File, 1980.

MORGENTHAU, Hans J., A Política Entre as Nações, Brasília, Editora Universidade de Brasília, 2003.

NEUMANN, Franz, Behemot: Pensamiento y acción en el nacional-socialismo, México, Fondo de Cultura Economica, 1943.

NIETZSCHE, Friedrich, The Antichrist, Nova York, Viking, 1954.

NISBET, Robert, History of the Idea of Progress, New York, Basic Books, 1980.

NOLTE, Ernest, La Guerra Civil Europea, 1917-1945 - 2ª ed, México, D.F., Fondo de Cultura Econômica, 1994.

OPPENHEIMER, H., Constitution of the German Republic, London, Stevens \& Sons, 1921.

PAXTON, Robert O., A Anatomia do Fascismo, São Paulo, Paz e Terra, 2007.

PEDROSA, Mário, Mundo, Homem, Arte em Crise, São Paulo, Perspectiva, 1975.

PETROPOULOS, Jonathan, Art as Politics in the Third Reich, USA, University of North Carolina, 1996.

PROUDHON, Pierre- Joseph, Política, São Paulo, Abril Cultural, 1986.

ROSENBERG, Arthur, Imperial Germany: The Birth of the German Republic 18711918, Boston, Beacon Press, 1964

SCHMITT, Carl, O Guardião da Constituição, Belo Horizonte, Del Rey, 2007 , Legalidade e Legitimidade, Belo Horizonte, DelRey, 2007. p. 71-79 , La Dictadura, Madrid, Alianza, 2007, p. 260 , Romanticismo Político, Buenos Aires, Universidad Nacional de Quilmes, 2000. , The Crisis of Parliamentary Democracy, Massachusets, MIT Press, 1988. 
Teologia Política, Belo Horizonte, Del Rey, 2006.

SCHEPPELE, Kim Lane, "Law in a Time of Emergency: States of Exception and the Temptations of 9/11". University of Pennsylvania Journal of Constitutional Law, Vol. 6, 2004.

SCHUMPETER, Joseph. Capitalismo, socialismo e democracia, Rio de Janeiro, Zahar, 1984.

SHIRER, William L., Ascensão e Queda do Terceiro Reich - 4 vols, Rio de Janeiro, Civilização Brasileira, 1967.

SPANGENBERG, Berthold (introdução), German Cultural History, Munich, Nymphenburger, 1983.

SPEER, Albert, Por Dentro do III Reich, São Paulo, Círculo do Livro, 1975.

STIRK, Peter M. R., "Hugo Preuss, German political thought and the Weimar constitution”, in History of political thought., 23 (3), Durham, University Library, 2002 TAYLOR, A. J. P., The Course of German History, Londres, Routledge Classics, 2001. , The Origins of the Second World War, New York, Simon \& Schuster, 2005.

THALMANN, Rita, A República de Weimar, Rio de Janeiro, Jorge Zahar, 1988.

THOMAS, Karin, Bis heute: Stilgesschichte der Bildenden Kunst im 20 Jahrhundert, Köln, Dumont Buchverlag, 1944.

TOUGAN-BARANOWSKY, Michel. L'Evolution historique du socialisme moderne. Paris, Riviere, 1913

TROTSKY, Leon, A arte da Insurreição, São Paulo, Edições Pulsar, 2000. , Política, São Paulo, Ática, 1981. A História da Revolução Russa - A Queda do Tzarismo - $2^{a}$ ed, Rio de Janeiro, Paz e Terra, 1977. 
A História da Revolução Russa -A Tentativa da Contra- Revolução - $3^{a}$ ed, Rio de Janeiro, Paz e Terra, 1980.

, A História da Revolução Russa - O Triunfo dos Sovietes - $3^{a}$ ed, Rio de Janeiro, Paz e Terra, 1980.

, Germany, 1931-1932, Londres, New Park Publications, 1970.

, Fascism: What It Is and How to Fight It, Nova Iorque, Pathfinder Press, 1993.

, Revolução e Contra-Revolução na Alemanha, São Paulo, Livraria Ciências

Humanas, 1979.

VOEGELIN, Eric, Hitler e os Alemães, São Paulo, É Realizações, 2008.

VOLKOGONOV, Dmitri, Stalin - 1879-1939, Rio de Janeiro, Nova Fronteira, 2004.

, Stalin - 1939-1953, Rio de Janeiro, Nova Fronteira, 2004.

WALTZ, Kenneth, Man, The State, and War - $2 a$ ed, Columbia, Columbia University Press 2001.

WEBER, Max, Ciência e Política: Duas Vocações, São Paulo, Cultrix, 2000.

WIGHT, Martin, A Política do Poder, Brasília, Editora Universidade de Brasília, 2002.

WILHELM II, The Kaiser’s Memoirs, New York, Harper \& Brothers, 1922.

http://www.gonschior.de/weimar/Deutschland/Uebersicht_RTW.html, consultado em 07/07/2009, às 15h00

http://www.reference.com/ consultado em 07/07/2009, às 15h00 


\section{Anexos}

\subsection{A Constituição da República de Weimar ${ }^{227}$.}

\section{The Reich Constitution of August 11th 1919 (Weimar Constitution)}

The German people, united in its tribes and inspirited with the will to renew and strengthen its Reich in liberty and justice, to serve peace inward and outward and to promote social progress, has adapted this constitution.

\section{First Part}

\section{Composition of the Reich and its Responsibility}

\section{First Chapter : the Reich and the States}

\section{Article 1}

The German Reich is a republic.

State authority derives from the people.

\section{Article 2}

State territory of the Reich is composed of the territories of the German states.

Other areas may be included in the Reich, if their population desires in exercise of its right of self-determination.

\section{Article 3}

The Reich colours are black-red-golden. The merchant flag is black-white-red, with the Reich colours in the upper, inner corner.

\section{Article 4}

The generally recognised rules of international law are valid as binding elements of German Reich law.

\section{Article 5}

State authority is exercised in Reich affairs by the government organizations of the Reich, based on the Reich constitution, in state affairs by the government organizations, based on the respective state constitutions.

\section{Article 6}

The Reich exclusively exercises legislation in the following areas :

1. foreign relations

2. colonial affairs

3. nationality, freedom of movement, immigration and emigration as well as extradition

4. national defense

5. national currency

6. customs service, the union of the customs and trade territory, freedom of movement of merchandise

\footnotetext{
${ }^{227}$ http://www.reference.com/ consultado em 07/07/2009, às 15 h00
} 
7. postal and telegraph service including telephone service

\section{Article 7}

The Reich is responsible for legislation in the areas

1. civil law

2. penal law

3. jurisdiction including the execution of sentences as well as judicial assistance between government offices

4. passport affairs and the registration of aliens

5. welfare for the poor and the migrants

6. press, clubs, assemblies

7. population policy, motherhood, baby, children and youth welfare

8. health care, veterinary affairs, protection of plants against diseases and parasites

9. labour legislation, insurance and protection of workers and employees as well as certification of employment

10. the establishment of institutions representing occupations within the Reich territory

11. welfare for combattants and their surviving dependants

12. the law of expropriation

13. the nationalization of natural resources, of economic enterprises, of the production, distribution and pricing of merchandise for the social economy

14. trade, measurements, the distribution of paper money, construction and stock markets

15. the sale of food as well as other goods of daily consumption

16. industry and mining

17. insurances

18. merchant shipping. ocean and coastal fishing

19. railways, inland navigation, motor vehicle traffic on land, water and in the air, the construction of overland roads, as far as these serve general traffic and national defense 20. theatres and cinemas

\section{Article 8}

The Reich furthermore is responsible for legislation regarding taxation and other revenues, as far as they are fully or partly used to pay its expenses. If the Reich uses taxation which hitherto has contributed to the budget of the states, it has to consider the viability of the states.

\section{Article 9}

Insofar there is need for the formulation of standardized regulations, the Reich has the legislation over

1. welfare system

2. protection of law and order

\section{Article 10}

The Reich may, via legislation, establish principles for:

1. the rights and obligations of religious communities

2. the education system, including universities and scientific libraries

3. the rights of Beamte in all public bodies

4. law pertaining land, its distribution, settlement, obligations coming with ownership of land, housing and the distribution of population

5. funerals 


\section{Article 11}

The Reich can, by the means of legislation, establish principles for the legality of and the manner of collection of state dues/taxation, as far as necessary, in order to

1. avoid the diminution of Reich revenue or damage to the Reich trade relations

2. avoid double taxation

3. avoid excessive or obstructive burdens in forms of tolls on the use of public roads or institutions

4. avoid the discrimination against imported goods, as compared to domestically produced goods, via taxation, in trade between the individual states and their parts or 5. avoid the subvention of exports or to preserve important interests of society.

\section{Article 12}

As far and as much the Reich does not make use of its right to legislate, the states are entitled to legislate. This does not apply to the areas in which the Reich has the exclusive right to legislate.

When it comes to state laws pertaining Article 7 Number 13, the Reich government, inasfar the welfare of the Reich is concerned, has the right to object.

\section{Article 13}

Reich law breaks state law.

If there are doubts or opposing opinions regarding if a state regulation harmonizes with Reich law, the respective Reich or central state authority may request, according to the specifications of Reich law, the Reich supreme court to decide in the matter.

\section{Article 14}

Reich laws are executed by state authorities, inasfar Reich laws do not specify otherwise.

\section{Article 15}

Reich government exercises supervision in those matters in which it is responsible for legislation.

If Reich laws have to be executed by state authorities, the Reich government may establish general directions. It is entitled to send inspectors to the central state authorities, and with their approval, to their subaltern authorities, for the purpose of supervision.

The state governments are obliged, at the request of the Reich government, to eliminate problems which have occurred when Reich laws were executed. In case of conflicting opinions both Reich government as well as state government may request the decision of the supreme court, inasfar Reich law does not specify another court as responsible.

\section{Article 16}

Beamte in charge of immediate Reich administration in the states shall normally be state citizens. The Beamte, employees or workers working for the Reich administration are, at their request, to be employed in their home regions, as far as possible, and as far as their qualification respectively the conditions of service do not provide otherwise.

\section{Article 17}

Every state must have the constitution of a free state. State parliament must be elected in a general, equal, immediate and secret ballot, in which all Reich German men and women participate, according to the principles of representative election. The state 
government requires the confidence of state parliament.

The principles for the election of state parliament also apply for local elections. State law may determine if those who lived in the community for one year or less may participate in the election or not.

\section{Article 18}

The organization of the Reich in states, as far as possible under consideration of the will of the concerned population, shall serve the people's maximal economic and cultural achievement. The transfer of state territory within the Reich, the formation of new states within the Reich is conducted by a Reich law amending the constitution.If the concerned states agree, a simple Reich law may suffice.

A simple Reich law may also suffice, if one of the concerned states does not agree, yet the territorial alteration or new formation is demanded by popular will or necessary because of a superceding Reich interest.

Popular will has to be established by plebiscite. The Reich government may order a plebiscite, if one third of the enfranchised inhabitants in the area to be separated demands so.

Three fifth of the votes handed in, and at least the majority of the population are necessary in order to decide on the alteration of territory. Even if only the separation of a part of a Prussian administration district, a Bavarian circle or a respective territorial unit in another state is concerned, the will of the population of the entire unit has to be determined. If the concerned area is not geographically connected with the remainder of the respective administrative unit, the will of the area to be separated may, based on a special Reich law, be regarded as sufficient. After approval of the population has been established, the Reich government has to present a respective law draft to the Reichstag (4) to decide upon. If, during separation or integration, a dispute arises over matters of treasury or debts, the Reich state court will decide for the Reich, at the request of any party involved.

\section{Article 19}

Regarding constitution disputes within a state, where no court is responsible to deal with, as well as in disputes of non-private matter between various states or between a state and the Reich, the Reich state court, at the request of one party, decides in the name of the Reich, unless another Reich court is responsible.

The Reich president executes decisions of the Reich state court.

\section{Second Chapter : The Reichstag}

Article 20

The Reichstag is composed by the representatives elected by the German people.

\section{Article 21}

Members of parliament represent the entire nation. They have to follow nothing but their conscience and they are not bound to instructions.

\section{Article 22}

Members of parliament are elected in a general, equal, immediate and secret election; voters are men and women older than 20 years; the election is held according to the principles of representative election. Elections must be held on a sunday or public 
holiday.

Further details are determined by the Reich election law.

Article 23

Reichstag is elected to serve for four years. The election of the next parliament has to be held, at the latest, on the 60th day after the expiration of the four-year term.

Reichstag has its first meeting, at the latest, on the 30th day after the election.

Article 24

Reichtag meets every year on the first Wednesday in November, at the seat of government. The Reichstag president has to call for a meeting beforehand, if it is demanded by the Reich president or by at least a third of the members.

Reichstag decides on the end of the debate and on the day the members reassemble.

\section{Article 25}

The Reich president has the right to dissolve the Reichstag, but only once for the same reason.

New elections, at the latest, are held 60 days after the dissolution.

Article 26

Reichstag elects its president, his vice-president and his secretaries.

Reichstag establishes its rules of procedure.

Article 27

In between sessions or election periods the outgoing president and vice-president continue to proceed business.

\section{Article 28}

The president exercises domestic right and police authority within the Reichstag building. He is responsible for the house's administration; he disposes over revenues and expenses, in accordance with the Reich budget, and he represents the Reich in all legal transactions and disputes concerning its administration.

\section{Article 29}

Reichstag sessions are public. If fifty members apply and a majority of two thirds decide in favour, the public can be excluded.

\section{Article 30}

True reports on the negotiations in public Reichstag debates, of state Landtag debates or of the debates of their commissions are free of any liability.

\section{Article 31}

At Reichstag an Election Investigation Court will be established. It will decide if a representative has lost his mandate. The Election Investigation Court will be composed of members of the Reichstag, elected for the actual term, and by members of the Reich Administration Court, appointed by the Reich President at the suggestion of the Reich Administration Court board. The Election Investigation Court will decide based on a public, oral session held by three members of the Reichstag and two noble members. Outside of the procedures in the Election Investigation Court, the matter will be handled 
by a Reich Commissioner, appointed by the Reich President. Further, the procedure will be regulated by the Election Investigation Court.

\section{Article 32}

To establish a decision in Reichstag, a simple majority of votes suffices, unless the constitution prescribes a different relation of votes. During Reichstag elections the rules of procedure may permit exceptions. The rules of procedure establish quorum.

\section{Article 33}

Reichstag and its committees can demand the presence of the Reich chancellor as well as that of every individual Reich minister.

The Reich chancellor, the Reich ministers and their commissioners have the right to participate in sessions of Reichstag and its committees. The states are entitled to send authorized representatives, who present the position of their state's government, into these sessions. At their request the state representatives have to be heard; the Reich representatives also, even if this is not included in the agenda. The Reichstag or Committee

President is responsible for order.

\section{Article 34}

Reichstag is entitled to, and in case a fith of its members move for it, is obliged to establish inquiry committees. Such committes collect, in public sessions, evidence they or the movers regard necessary. The inquiry committee can exclude the public if two thirds of its members vote for doing so.

Committee procedures are regulated by the rules of procedure, which also fixes the number of its members.

Courts and administrations are obliged to answer the committee requests; administration records have to be presented to them upon request.

The committee investigations as well of the administration as requested by the committees, underlie the specifications of the code of criminal procedure; however, secrecy of mail, telegraphs, telephone calls remain untouched.

\section{Article 35}

Reichstag establishes a standing committee for foreign affairs, which also meets when Reichstag is not in session, after the term is expired or after Reichstag has been dissolved, until a new Reichstag meets for the first time. Their sessions are not public, unless two thirds of its members vote to hold a public session.

Reichstag furthermore establishes a standing committee to safeguard the rights of parliament juxtaposed Reich government, for the time when parliament is not in session [or], after a term has expired or Reichstag has been dissolved, until a new Reichstag has assembled.

These committees have the status of inquiry committees.

\section{Article 36}

No member of Reichstag or of any Landtag may be persecuted by court at any time for statements he made in exercise of his mandate, in a vote, in parliament session or outside of the assembly.

\section{Article 37}

No member of Reichstag or of a Landtag may, without approval by the house the person 
in question is member of, for the term of session, be arrested or interviewed in the investigation of an punishable activity, unless the member was caught in the act or at least the day after.

The same approval is required for any other limitation of personal liberty which might harm the member's ability to fulfil his mandate.

Any criminal procedure against a Reichstag or Landtag member, any detention or otherwise limitation of his personal liberty will be, at the house's request, suspended for the duration of the legislative period.

\section{Article 38}

The members of Reichstag and of the Landtags are entitled, in matters concerning persons who told them, in their function as members of parliament, confidential information, or whom they, in exercise of their mandate, gave confidential information, to refuse answering questions in that regard.

When it comes to the confiscation of written documents they have to be given the same treatment as those who have the privilege to refuse testimony.

In the rooms of the Reichstag or of any Landtag, any search or confiscation may only be undertaken with the permission of the house president.

\section{Article 39}

Beamte and soldiers, in exercise of their Reichstag or Landtag mandate, do not require leave. If they run for parliament, they have to be granted adequate leave.

\section{Article 40}

Reichstag members enjoy the privilege of free transportation on German railways and will be compensated for their travel expenses according to a Reich law.

\section{Article 40 a}

The validity of regulations of articles 36, 37, 38 paragraph 1 and 39 paragraph 1 for the Reichstag President, his deputies, the permanent members of the committees listed in article 35 and their deputized members in first degree, extend into the period between two legislative periods or Reichstag election periods.

The same is the case for the president of a Landtag, his deputies and the permanent members of committees and their deputized members, if the latter two can continue their activity after the termination of the legislative period.

If article 37 stipulates the participation of Reichstag or Landtag, the committee, to safeguard the interests of parliament, takes the place of Reichstag and, if Landtag committees continue, the committee established by Landtag takes the place of Landtag. The persons listed in paragraph 1 enjoy the rights described in article 40 also in the time between two legislative period.

\section{Third Chapter : The Reich President and Reich Government}

\section{Article 41}

The Reich President is elected by the entire German nation.

Every German who has finished the 35th year of his life is eligible. Further details are provided by a Reich law.

\section{Article 42}

The Reich President, when taking his office, swears the following oath : 
I swear to devote my energy to the welfare of the German people, to increase its prosperity, to prevent damage, to hold up the Reich constitution and its laws, to consciously honour my duties and to exercise justice to every individual. The addition of a religious formula is acceptable.

\section{Article 43}

The term of office of the Reich President lasts seven years. Reelection is permitted. The Reich President can be deposed by plebiscite, which has to be suggested by the Reichstag. This Reichstag decision requires a majority of two thirds of the votes. Such a decision bars the Reich President from continued exercise of his office. A rejection of the deposition is regarded as a reelection and results in the dissolution of the Reichstag. The Reich President can not be persecuted in a penal matter without the approval of Reichstag.

\section{Article 44}

The Reich President may not simultaneously be member of Reichstag.

\section{Article 45}

When it comes to international law, the Reich is represented by the Reich President. He concludes alliances and other treaties with foreign powers in the name of the Reich. He accredits and receives ambassadors.

War can only be declared and peace only be signed by Reich law.

Alliances and treaties which relate to matters of Reich legislation require the approval of Reichstag.

\section{Article 46}

The Reich President appoints and discharges Reich Beamte and officers, unless specified otherwise by Reich law. He may have other administrations take charge of

\section{Article 47}

The Reich President has the supreme command over the armed forces, in their entirety.

\section{Article 48}

If a state does not fulfil the obligations laid upon it by the Reich constitution or the Reich laws, the Reich President may use armed force to cause it to oblige. In case public safety is seriously threatened or disturbed, the Reich President may take the measures necessary to reestablish law and order, if necessary using armed force. In the pursuit of this aim he may suspend the civil rights described in articles 114, 115, $117,118,123,124$ and 154, partially or entirely.

The Reich President has to inform Reichstag immediately about all measures undertaken which are based on paragraphs 1 and 2 of this article. The measures have to be suspended immediately if Reichstag demands so.

If danger is imminent, the state government may, for their specific territory, implement steps as described in paragraph 2. These steps have to be suspended if so demanded by the Reich President or the Reichstag. Further details are provided by Reich law.

\section{Article 49}

The Reich President exercises the right of amnesty. Reich amnesties require a Reich law. 


\section{Article 50}

All orders and edicts by the Reich President, including such pertaining the armed force, in order to gain validity, require the countersignature of the Reich Chancellor or the responsible Reich ministers. The countersignatory assumes responsibility.

\section{Article 51}

In case the Reich President is unavailable, he is briefly substituted by the Reich Chancellor. Is it a presumably longer lasting situation, his substitution has to be regulated by a Reich law.

The same applies in case a presidency ends prematurely, until the next election is held.

\section{Article 52}

The Reich government consists of the chancellor and the Reich ministers.

\section{Article 53}

The Reich chancellor, and, at his request, the Reich ministers, are appointed and dismissed by the Reich President.

\section{Article 54}

The Reich chancellor and the Reich ministers, in order to exercise their mandates, require the confidence of Reichstag. Any one of them has to resign, if Reichstag votes by explicit decision to withdraw its confidence.

\section{Article 55}

The Reich chancellor presides the Reich government and conducts its affairs according to the rules of procedure, to be decided upon by Reich government and to be approved by the Reich president.

\section{Article 56}

The Reich chancellor determines the political guidelines and is responsible for them to Reichstag. Within these guidelines every Reich minister leads his portfolio independently, and is responsible to Reichstag.

\section{Article 57}

Reich ministers have to present all law drafts, as well as matters for which constitution or laws proscribe this procedure, and divergent opinions in questions which relate to the portfolios of several Reich ministers, for consultation and decision.

\section{Article 58}

Reich government decides by majority of votes. In case of a stalemate the president's vote is decisive.

\section{Article 59}

Reichstag is entitled to accuse Reich President, Reich chancellor and the Reich ministers at the Supreme Court, in the name of the German Reich, of having guiltconsciously having violated the Reich constitution or a Reich law. The move to accuse must be signed by at least a hundred members and requires the approval of the majority necessary to amend the constitution.

Further details are regulated by the Reich law concerning the Supreme Court. 


\section{Fourth Chapter : The Reichsrat}

\section{Article 60}

To represent the German states in Reich legislation and administration, a Reichstag is formed.

\section{Article 61}

Every state has minimum one vote in the Reichstag. In case of larger states, they have one vote for every 700.000 inhabitants. If there is a surplus of 350.000 inhabitants, they are calculated as 700.000. No state may have more than two fifth of all votes.

Deutsch sterreich is entitled, after its integration into the German Reich, to send the number of delegates to the Reichsrat which corresponds to its population. Until then, the representatives of Deutschosterreich have only advisory vote.

The number of votes will be newly established after every general census.

\section{Article 62}

No state is represented by more than one delegate in the committees formed by the Reichsrat.

\section{Article 63}

In the Reichsrat, the states are represented by members of their respective governments. However, half the number of the Prussian delegates will be sent by the Prussian provincial administrations, in accordance to a Prussian state law.

The states are entitled to send as many delegates to the Reichsrat as they have votes.

\section{Article 64}

The Reich government has to call for Reichsrat to assemble if one third of the Reich Council members demand so.

\section{Article 65}

Presidency in the Reichsrat and in its committees is exercised by a member of Reich government. The members of Reich government have the right, and upon request are obliged to join meetings of the Reich Council and its committees. During the deliberations they have to be heard any time.

\section{Article 66}

Reich government and every individual member of Reichsrat are entitled to propose a move in the Reichsrat.

Reichsrat regulates its course of business by its rules of procedure.

Plenary assemblies are public. According to the rules of procedure, in case certain topics are discussed, the public may be excluded.

Simple majority of the voters decides a vote.

\section{Article 67}

Reich ministers have to inform Reichsrat over the conduct of Reich administration. In case important topics are discussed, the Reich ministries shall consult the respective Reichsrat committee.

\section{Fifth Chapter : Reich Legislation}




\section{Article 68}

Law drafts are proposed by members of the Reich government or from Reichstag members.

Laws are passed by Reichstag.

\section{Article 69}

Law drafts proposed by the Reich government require the approval of Reichsrat. If Reich government and Reichsrat cannot agree, Reich government may still propose the law, but has to present the divergent Reichsrat opinion as well. If Reichsrat passes a law draft which is not approved by the Reich government, the latter has to present the draft, with its divergent comment, to Reichstag.

\section{Article 70}

The Reich president has to sign laws which have been passed according to the constitutional process, and to publish them within one month in the Reich law gazette.

\section{Article 71}

Unless otherwise specified, Reich laws take force 14 days after being published in the Reich law gazette in the Reich capital.

\section{Article 72}

The proclamation of a Reich law has to be postponed for two months, if one third of the Reichstag members demand so. Laws labelled urgent by both Reichstag and Reichsrat can be proclaimed by the Reich president, disregarding the demand aforementioned.

\section{Article 73}

A law passed by Reichstag has to be presented in a plebiscite, if the Reich president decides so, within the period of one month.

A law, the proclamation of which has been suspended because of a move supported by minimum one third of the members of Reichstag has to be presented in a plebiscite, if one twentieth of the enfranchised voters demand so.

A plebiscite also has to be held if one tenth of the enfranchised voters demand a law draft to be presented. In order for a referendum petition to be approved, a law draft must be prepared. It has to be presented to Reichstag by the government, accompanied by the latter's comment.

The plebiscite will not be held, if the law draft in question has been accepted unaltered by Reichstag.

In regard to the budget, taxation laws and pay regulations, only the Reich president can request a plebiscite. Plebiscite and referendum petitions are regulated by a Reich law.

\section{Article 74}

Reichsrat has the right to object to laws passed by Reichstag. The Reich government has to be notified of that objection within two weeks after the final decision in Reichstag, and has to be justified, at the latest, within a period of another two weeks.

In case of an objection the law will be presented a second time to Reichstag. If an agreement between Reichstag and Reichsrat cannot be achieved, the Reich president may, within a period of three months, call for a plebiscite.

If the president does not make use of this instrument, the law is to be regarded as not passed. Has Reichstag decided against Reichsrat objection with a vote of more than two 
thirds, the Reich president has, within three months, either to proclaim the law as decided or to call for a plebiscite.

\section{Article 75}

A plebiscite can override Reichstag decisions only if the majority of enfranchised voters participate.

\section{Article 76}

The constitution may be amended by legislation. Constitutional changes become valid only if at least two thirds of the members are present and at least two thirds of the present members vote in favour of the amendment.

Decisions of Reichsrat regarding a constitutional amendment also require a two-thirdsmajority. If, requested by referendum petition, a constitutional amendment shall be decided by plebiscite, the majority of the enfranchised voters is required in order for the amendment to pass.

If Reichstag decided on a constitutional amendment against Reichsrat objection, the Reich president may not proclaim the amendment, if Reichsrat, within a period of two weeks, demands a plebiscite to be held.

\section{Article 77}

Unless laws do not specify otherwise, the government will establish general administrative regulations. These require the approval of Reichsrat, if the execution of the Reich laws is the responsibility of State authorities.

\section{Sixth Chapter : Reich administration}

\section{Article 78}

Foreign relations are a matter of the Reich exclusively.

In matters which underlie state legislation, the states may sign treaties with foreign countries; these treaties have to be approved by the Reich.

Agreements with foreign countries concerning changes of the Reich borders may only be established if based on a Reich law, unless it is merely about a correction of the border in uninhabited areas.

In order to guarantee the representation of interests. which, for certain states, emerge out of special economic relations with or proximity to neighbouring countries, the Reich will decide appropriate institutions and measures in close consultation with the concerned states.

\section{Article 79}

Reich defense is a Reich matter. Military service will be regulated uniform, with consideration to regional traditions.

\section{Article 80}

Colonial affairs are exclusively Reich responsibility.

\section{Article 81}

All German merchant vessels form a uniform merchant fleet.

\section{Article 82}

Germany forms one customs and trade territory, surrounded by a common customs 
border.

This customs border coincides with the border separating Germany from foreign countries. On the sea, the coastline of the mainland and of the islands belonging to the Reich form the customs border. Concerning the customs border on the sea and at other bodies of water, alterations may be arranged.

Foreign state territories or parts thereof may be attached to the customs territory by international treaty or agreement.

Certain areas may be excluded from the customs territory, if certain special conditions apply. Concerning free ports, this exclusion can only be lifted by a constitution amending law.

Territories excluded from the German customs territory may be attached to a foreign customs territory by international treaty.

All products of nature. of craftsmanship and industry, which are freely traded within the Reich, may be ex-, imported and transported across the Reich. Exceptions, based on a Reich law, are permissible.

\section{Article 83}

Customs and consumption taxes are managed by the Reich administration.

When it comes to the management of Reich taxation by Reich offices, institutions have to be established which safeguard special state interests in the areas of agriculture, trade and industry.

\section{Article 84}

The Reich, by the means of legislation, establishes regulations for :

1. the establishment of state taxation management, inasmuch a uniform and equanimous application of Reich taxation laws require;

2. the establishment and authority of the administration branches responsible for the supervision of the execution of Reich taxation laws;

3. the clearing with the states;

4. compensation for the costs of administration caused by the execution of Reich taxation laws.

\section{Article 85}

All Reich revenues and expenses have to be calculated for every single financial year and have to be included in the budget.

The budget is determined before the financial year begins. Under normal circumstances, the expenses are approved for one year; under extraordinary circumstances they can be approved for a longer period. Otherwise, regulations within the budget extending over the period of one year, or which do not deal with the Reich's revenues or expenses, are not permissible. In the budget, Reichstag may not raise expenses in the budget without the approval of Reichsrat.

Reichsrat approval may be replaced by the specifications in Article 74 .

\section{Article 86}

Regarding the utilization of the Reich's revenues, the minister of finances, in the name of the Reich government, will report to Reichsrat and Reichstag. Auditing will be regulated by a Reich law.

Article 87

Only in case of extraordinary demand, and normally only for the purpose of paying for 
advertisement, may funds be acquired by the means of credits.

Such acquisition, as well as reliability at the Reich's expense, may only be undertaken if based on a Reich law.

\section{Article 88}

Post and telegraph service is to be administrated exclusively by the Reich.

Within the entire Reich, uniform postage stamps are used.

The Reich government establishes, with Reichsrat approval, regulations which fix principles and fees for the use of public infrastructure. It may transfer this authority, with Reichsrat approval, to the minister of posts and telegraphs.

In order to consult it in postal, telegraph and telephone affairs, the Reich government, with Reichsrat approval, establishes an advisory council.

Treaties concerning the communication with foreign countries are exclusively concluded by the Reich.

\section{Article 89}

It is the Reich's task to take over the property of those railroads which serve public transportation, and to administrate them jointly. State claims to acquire private railroads are to be transferred to the Reich on demand.

\section{Article 90}

Together with the transfer of railroads in state property, the Reich claims the authority of expropriation and the state sovereignty rights concerning railroads.

In case of disagreement the supreme court will decide the extent of these rights.

\section{Article 91}

The Reich government, with Reichsrat approval, will establish regulations for the construction and maintenance of railways. It may transfer this authority, with Reichsrat approval, to the responsible Reich minister.

\section{Article 92}

The Reich railways are to the administrated as a separate economic enterprise, which has to balance its expenses including the payment of interests and downpayment of debt, and which has to establish a railroad fund, notwithstanding the inclusion of their budget and balance in the general Reich budget and balance.

The size of downpayment rates and of the railroad fund, as well as the utilization of the latter have to be determined by a separate law.

\section{Article 93}

The Reich government, with Reichsrat approval, establishes advisory councils to advise it in affairs concerning railroads and tariffs.

\section{Article 94}

If the Reich has taken over the railways serving general transportation in a certain area, only the Reich may construct new railways serving general transportation. If the construction of new railway lines or the alteration of existing railway lines interferes with state authority, the Reich railway administration has, before making a decision, to consult the state authorities.

In areas where the Reich has not yet taken railway lines serving general traffic under its administration, it may, even against the objection of those states whose territory is 
crossed, but without violating state sovereignty, construct railways at its own expense of have the railway construction to a third party, if necessary granting it the right to expropriate.

Every railway administration has to accept the connection of other railways, at the latter's expense.

\section{Article 95}

Railways serving general transportation, which are not administrated by the Reich, are subject to Reich supervision.

Railways under Reich supervision have to be constructed and equipped according to the same principles. They have to be maintained, to meet safety standards, and they have to be expanded if necessary. Persons and goods have to be transported in accordance with demand.

When it comes to the supervision of tariffs, emphasis is to be laid on uniform and low railway tariffs.

\section{Article 96}

All railways not serving general transportation have, in case of need, for the purpose of national defense, follow Reich instructions.

\section{Article 97}

It is the Reich's task to take waterways serving general transportation into Reich property and administration.

After the Reich has taken them over, new waterways may be constructed, and existing ones expanded, only by the Reich or with its approval.

When it comes to the administration, expansion or new construction of waterays, requirements state culture and water administration have to be considered, in communication with state authorities. The progress of state culture and water administration has to be considered.

Every waterway administration has to accept the connection of other inland waterways at the expense of the connecting entrepreneur. The same obligation is valid concerning the connection of inland waterways and railways.

Together with the transfer of the waterways the Reich claims the authority to expropriate, the authority to regulate tariffs and river police.

The Strombauverband responsibilities in the Rhine, Weser and Elbe areas are to be taken over by the Reich.

\section{Article 98}

The Reich government, with Reichsrat approval, establishes advisory councils to advise in waterways affairs.

\section{Article 99}

On natural waterways, fees may only be collected for works, institutions and installations which facilitate traffic. In case of state of communal installations they may not exceed the costs for construction and maintenance. In case of installations which do not exclusively serve traffic purposes, may only cover the proportionate fraction of their costs by fees

on shipping. Interest and downpayment on debts taken on to cover construction expenses are to be regarded as construction expenses.

The aforelisted regulations apply to fees collected on artificial waterways, on 
installations adjacent to them and in harbours.

In inland navigation waterway usage fees may be calculated on the basis of an individual waterway, a river basin or a network of waterways.

These regulations also apply for log drifting on navigable waterways. Only the Reich is entitled to establish a set of fees which impose higher fees on foreign ships than those taken from German ships.

In order to acquire the means to maintain and extend the German network of waterways, the Reich may, by the means of a law, ask those concerned with the navigation to contribute in other ways.

\section{Article 100}

To cover the expenses for maintenance and construction of inland waterways, by Reich law, also those can be asked to contribute who profit in ways other than navigation from the construction of artificial dams, if several states are concerned or the Reich finances the dam.

\section{Article 101}

It is the Reich's responsibility to take possession of all nautical marks, especially lighthouses, light vessels, buoys, tons and beacons and to organize their administration and maintenance. After the takeover, nautical marks may only be produced and/or expanded by the Reich or with its approval.

\section{Seventh Chapter : Jurisdiction}

\section{Article 102}

Judges are independent and subject only to the law.

\section{Article 103}

Ordinary jurisdiction is exercised by the Reich court and the state courts.

\section{Article 104}

Judges serving ordinary jurisdiction are appointed for lifetime.

Against their will they can only be suspended temporarily or forced into early retirement or transferred to another location if a judge decided so, based on reasons and according to procedures determined by law. Legislation may establish an age limit, at which judges retire.

Preliminary suspension conform with the law will not be affected.

In case of a change in the institution of courts or their districts the state administration of justice may order the involuntary transfer of judges to another court or out of office, but only under the condition that their salary will be paid continuously.

These regulations do not affect commercial judges, lay assessors and jury members.

\section{Article 105}

Extraordinary courts are inadmissible. Nobody may be deprived of his ordinary judge. Legal regulations concerning military jurisdiction and court martial are not affected hereby. Military courts of honor are abolished herewith.

\section{Article 106}

Military jurisdiction is to be lifted, except in times of war and on board of warships. Further details are given by a Reich law. 
Article 107

In the Reich and in the states administrative courts have to exist, according to the laws, to protect the individual against bureaucratic decrees.

\section{Article 108}

In accordance with a law, a supreme court will be established for the German Reich.

\section{Second Part \\ Basic rights and obligations of the Germans}

\section{First Chapter : The Individual}

\section{Article 109}

All Germans are equal in front of the law.

In principle, men and women have the same rights and obligations.

Legal privileges or disadvantages based on birth or social standing are to be abolished. Noble titles form part of the name only; noble titles may not be granted any more.

Titles may only be granted, if they indicate an office or occupation; academic degrees are not affected by this regulation.

The state may no more bestow orders and medals.

No German may accept titles or orders from a foreign government.

\section{Article 110}

Nationality in the Reich and in the states is acquired and lost according to the specifications of a Reich law. Every state national simultaneously is Reich national. Every German, in every state, enjoys the same rights and obligations as the respective state nationals.

\section{Article 111}

All Germans enjoy freedom to move and settle down. Everybody is entitled to stay and settle anywhere within the Reich, to acquire property and to pursue his trade.

Limitations require a Reich law.

\section{Article 112}

Every German is entitled to emigrate into non-German countries. Emigration can only be limited by a Reich law.

All Reich Germans are entitled to Reich protection against foreign administrations, within and outside of the Reich.

No German may be extradited to a foreign country.

\section{Article 113}

Reich communities speaking a foreign language may not be deprived by legislation of their national identity, especially in the use of their mother language in education, in local administration and jurisdiction.

\section{Article 114}

The rights of the individual are inviolable. Limitation or deprivation of individual liberty is admissible only if based on laws.

Persons deprived of their liberty have to be notified, at the next day on the latest, by which authority and based on which reasons the deprivation of their liberty has been 
ordered; immediately they have to be given the opportunity to protest against the deprivation of liberty.

\section{Article 115}

Every German's home is an asylum and inviolable. Exceptions are admissible only if based on a law.

\section{Article 116}

An action can only be punished if the action has been described as punishable by law, before the action was undertaken.

\section{Article 117}

Privacy of correspondence, of mail, telegraphs and telephone are inviolable. Exceptions are admissible only if based on a Reich law.

\section{Article 118}

Every German is entitled, within the bounds set by general law, to express his opinion freely in word, writing, print, image or otherwise. No job contract may obstruct him in the exercise of this right; nobody may put him at a disadvantage if he makes use of this right.

There is no censorship; in case of the cinema, other regulations may be established by law. Also in order to combat trashy and obscene literature, as well as for the protection of the youth in public exhibitions and performances legal measures are permissible.

\section{Second Chapter : Life within a Community}

\section{Article 119}

Marriage, as the foundation of the family and the preservation and expansion of the nation, enjoys the special protection of the constitution. It is based on the equality of both genders.

It is task of both the state and the communities to strengthen and socially promote the family. Large families may claim social welfare.

Motherhood is placed under state protection and welfare.

\section{Article 120}

It is the supreme obligation and natural right of the parents to raise their offspring to bodily, spiritual and social fitness; the governmental authority supervises it.

\section{Article 121}

Legislation has to create equal preconditions for children born out of wedlock, concerning their bodily, spiritual and social development, as they are given to legitimate children.

\section{Article 122}

Youth is to be protected against exploitation as well as against moral and spiritual dissipation, bodily neglect. State and communities have to take appropriate measures. Measures which interfere by the means of force in the parents' right to raise their children may only be taken if based on a law. 
Article 123

All Germans have the right to assemble peacefully and unarmed; such assemblies do not require any prior notification or special permit.

A Reich law can require prior notification for assemblies taking place in the open, and it can, in case of imminent danger for public security, stipulate that such assemblies in the open may be prohibited.

\section{Article 124}

All Germans are entitled, for means which do not conflict with penal laws, to form clubs or societies. This right may not be limited by preventive measures. These regulations also apply for religious societies.

Every club is free to acquire legal capacity. No club may be denied of it because of it pursuing political, socio-political or religious goals.

\section{Article 125}

Liberty and secrecy of ballot are guaranteed. Further details are specified by election laws.

\section{Article 126}

Every German is entitled to address the respective authority or parliament with petitions or grievances. This right may be exercised both by the individual or jointly by a group of individuals.

\section{Article 127}

Communities and associations of communities are entitled to self-administrations, within the limits set by law.

\section{Article 128}

All citizens, without discrimination, are to be admitted, according to their talents and accomplishments, to public office.

All regulations discrimination against female Beamte are abolished. The status and working conditions of Beamte have to be regulated by Reich law.

\section{Article 129}

Beamte are employed for lifetime, unless specified otherwise by law. Pension and dependents' pensions are regulated by law. Beamte's acquired rights are inviolable. Beamte are entitled to take the course of law to claim their proprietary claims. Only under certain conditions and procedures, specified by law, may Beamte be suspended temporarily or to be retired of to be transferred into another office with lower pay.

The opportunity to appeal against any official penalization, and to request reinstatement, must be given. Negative entries may only then be written in personal records if the respective Beamter has been given the opportunity to comment. The Beamte has to be given access into his personal records.

The inviolability of his acquired rights and the option to take the course of law are guaranteed especially for the professional soldier. Their status otherwise is regulated by Reich law.

Article 130

Beamte serve society in its entirety, not a specific party. All Beamte enjoy freedom of 
political opinion any freedom to join clubs and organizations.

According to legal Reich specification, Beamte will be given specific Beamte representation.

\section{Article 131}

If a Beamter, in exercise of public authority entrusted on him, violates his obligation of office toward a third person, responsibility falls fundamentally upon the state or the corporation in the service of which the Beamte acts. Recourse agaist the Beamte is reserved. The course of law may not be excluded. Further details are to be provided by competent legislation.

\section{Article 132}

Every German is, in accordance with the law, obliged to take on honorary activities.

\section{Article 133}

All citizens are obliged, in accordance with the law, to provide personal services for state and community.

Compulsory military service is regulated by the specifications of the Reich defense law. This also stipulates inhowfar the individual's rights are to be limited in order to uphold discipline and for the Wehrmacht to fulfil its tasks.

\section{Article 134}

All citizens without discrimination contribute in relation to their means to the public burden, in accordance with the laws.

\section{Third Chapter : Religion and Religious Communities.}

\section{Article 135}

All Reich inhabitants enjoy full freedom of liberty and conscience. Undisturbed practise of religion is guaranteed by the constitution and is placed under the protection of the state. General state laws are not affected hereby.

\section{Article 136}

Civil and civic rights and obligations are neither conditioned nor limited by the exercise of freedom of religion. The exercise of civil or civic rights, the admittance to public offices are independent of religios confession.

Nobody is obliged to profess his religious confession publicly. Public authority may only ask for religious affiliation as far as rights and obligations derive or an officialy decreed census requires. Nobody may be forced to participate in a religious act or festivity, to join in religious practices or to swear a religious oath formula.

\section{Article 137}

There is no state church.

Freedom to form religious communities is guaranteed. Regarding the unification of religious communities within the Reich territory there are no limitations.

Every religious community administrates its own affairs without interference of state or community.

Religious communities acquire legal capacity according to general specifications of civil law.

Religious communities, as far as they have been, remain public corporations. 
Other religious societies have to be granted the same rights on application, if they, by the means of their number and constitution, indicate to be lasting. If several religious communities with the status of public corporations form a confederation, the status of public corporation is extended to this confederation.

Religious communities with the status of public corporations are entitled to raise taxes based on fiscal records and in accordance with state regulations.

Religious communities are given equal status with civic organizations which cultivate a philosophy of life.

Inasmuch as the application of these regulations requires further details, these have to be established by state legislation.

\section{Article 138}

State contributions to religious communities, inasmuch they are based on law, treaty or specific legal claim, are to be handled by state legislation.

The Reich provides the principles herefor.

The religious communities' and organization's right to own institutions serving public welfare, education and religious service, to own respective endowments and other property are guaranteed.

\section{Article 139}

Sunday and other state holidays are designated as days of rest from work and spiritual collection and are, as such, protected by law.

\section{Article 140}

Soldiers have to be given appropriate free time to fulfil their religious obligations.

\section{Article 141}

Insofar there is demand for religious service and ministerial work in the army, in hospitals, prisons or other public institutions, religious organizations have to be permitted to take care of these, and they have to ke kept clear of any form of force.

\section{Fourth Chapter : Education and School.}

\section{Article 142}

The arts, science and instruction are free. State provides protection and participates in its cultivation.

\section{Article 143}

The education of the youth has to be provided by public institutions. In their establishment, Reich, states and communities cooperate.

The training of teachers has to be regulated uniform for the Reich, according to principles applying generally for higher education.

Teachers at public schools enjoy the rights and share the duties of state Beamte.

\section{Article 144}

Schooling entirely is placed under state supervision; the state can give a share in that supervision to the communities. School supervision is taken charge of by full-time, professionally qualified Beamte. 


\section{Article 145}

Schooling is obligatory. This obligation is served by the Volksschule with at least 8 school years and the school for further instruction, following on the former, until the completed 18th year. Instruction and learning aids are, at Volksschule and at schools for further instruction, free of charge.

\section{Article 146}

Public schooling has to be organized organically. Middle and high schools are based on an elementary school common for everybody. For the organization of the school system the variety of occupations, for the acceptance of a child into a school his talent and inclination, but not the economic and social position nor the religious confession of his parents are authoritative.

Within the communities, at the request of Erziehungsberechtigten, Volksschulen of their confession or world outlook have to be established, if this does not obstruct the regular operation of the school.

The wish of those Erziehungsberechtigter has, when possible, to be considered. Further details are specified by state legislation, according to principles laid down in a Reich law.

Reich, states and communities have to provide funds to allow poor children access to middle and high schools, to grant financial aid to parents, whose children are regarded qualified for the education on middle and high schools, until their education is ended.

\section{Article 147}

Private schools in lieu of public schools require state approval and are subject to state laws. Approval has to be granted, if the private schools do meet the standards of public schools in their educational goals as well as in their installations and in the qualification of their staff, and if they do not promote any differentiated treatment of children according to the wealth of their parents.

Approval has to be withheld, if the financial security of the teaching staff is insufficiently guaranteed.

Private primary schools are to be approved only, if there is no public primary school for a minority of persons with educational power which have applied for a school of their confession or world outlook according to Art.

146 Par. 2, or if the community recognizes a special educational interest.

Private preschools are to be abolished..

Private schools not competing with public schools continue under existing law.

\section{Article 148}

All schools have to work towards ethical education, patriotic spirit, personal and occupational fitness in the spirit of German nationality and international understanding. In the instruction at public schools it has to be taken into consideration not to hurt the feelings of dissenters.

Civics and teaching by doing are school subjects. Every pupil, upon graduation, will be given a copy of the constitution.

Secondary education, including Volkshochschulen have to be promoted by Reich, states and communities.

\section{Article 149}

Religious instruction is a regular subject at schools, except at schools without confession. Its instruction will be regulated by school legislation. 
It will be taught in accordance with the principles of the respective religious community, nothwithstanding the state's right of supervision.

Religious instruction and participation in religious activities remains a willful activity of teachers; in case of the children participation in religious instruction and ceremonies is left to the decision of those who have to decide over their religious education. Theological departments at universities continue to operate.

\section{Article 150}

Artistic, historical and natural monuments and the landscape enjoy state protection and care.

It is task of the Reich to prevent the export of German cultural property into foreign countries.

\section{Fifth Chapter : The Economy}

\section{Article 151}

The economy has to be organized based on the principles of justice, with the goal of achieving life in dignity for everyone. Within these limits the economic liberty of the individual is to be secured.

Legal force is permissible to realize threatened rights or in the service of superseding demands of public welfare.

Freedom of trade and industry will be realized according to a Reich law.

\section{Article 152}

Freedom of contract is the foundation of economic transactions, according to the laws. Usury is prohibited. Legal transactions offending good manners are invalid.

\section{Article 153}

Property is guaranteed by the constitution. Laws determine its content and limitation. Expropriation may only be decreed based on valid laws and for the purpose of public welfare. It has to be executed with appropriate compensation, unless specified otherwise by Reich law. Regarding the amount of the compensation, the course of law at general courts has to be kept open in case of a controversy, unless Reich laws specify otherwise. Expropriations by the Reich at the expense of the states, communities or charitable organizations may only be executed if accompanied by appropriate compensation. Property obliges. Its use shall simultaneously be service for the common best.

\section{Article 154}

The right of inheritance is guaranteed according to civil law. The state's share in the inheritance is determined by the laws.

\section{Article 155}

The distribution and usage of real estate is supervised by the state in order to prevent abuse and in order to strive to secure healthy housing to all German families, especially those with many children. War veterans have to be given special consideration in the homestead law to be written.

Real estate, the acquisition of which is necessary to answer the demand for housing, to promote settlement and cultivation of the soil and to elevate agricultural cultivation, may be expropriated. Fideicommissa are to be abolished.

The owner of the soil is obliged to the community to cultivate and exploit the soil. Any 
increase in the value of the real estate which does not result from the investment of labour or capital has to be made utilizable to the community.

All mineral wealth and all economically utilizable natural energy sources are under state supervision. Private rights are to be transferred into state property by the means of legislation.

\section{Article 156}

The Reich may transfer economic enterprises suited for nationalization into common property, if the regulations for expropriation are obeyed and if compensation is not violated. It may join in the administration of economic enterprises or syndicates or may order the states or communities to do so, or ot may otherwise assure decisive influence. In case of urgent demand the Reich furthermore may enforce the merger of economic enterprises and syndicates for the benefit of public welfare with the aim to assure the cooperation of all producing sections of the people,

in order to participate employers and employees in the administration, in order to regulate production, distribution, usage, pricing, im- and export of wares according to principles of the social economy.

Consumer and economic cooperatives and their federations are, upon their request and in consideration of their constitution and character, to be included in the social economy.

\section{Article 157}

Labour enjoys the special protection of the Reich. The Reich will provide uniform labour legislation.

\section{Article 158}

Intellectual creation, the rights of authors, inventors and artists enjoy protection and care of the Reich.

The achievements of German science, art and technology have to be given recognition and protection abroad by the means of international treaties.

\section{Article 159}

The right to form unions and to improve conditions at work as well as in the economy is guaranteed to every individual and to all occupations. All agreements and measures limiting or obstructing this right are illegal.

\section{Article 160}

Who is in the service or employment, be it as a worker or salaried employee, is entitled to make use of his civic rights, and, insofar no considerable economic damage results of it for the enterprise, to be granted the required free time for the exercise of public honorary offices bestowed upon him.

Insofar he is entitled to continue to receive his pay will be determined by law.

\section{Article 161}

In order to maintain health and the ability to work, in order to protect motherhood and to prevent economic consequences of age, weakness and to protect against the vicissitudes of life the Reich establishes a comprehensive system of insurances, based on the critical contribution of the insured. 


\section{Article 162}

The Reich advocates an international regulation of the rights of the workers, which strives to safeguard a minimum of social rights for humanity's working class.

\section{Article 163}

Notwithstanding his personal liberty, every German is obliged to invest his intellectual and physical energy in such a way as necessary for public benefit.

Every German shall be given the opportunity to earn his living by economic labor.

In case appropriate job openings can not be provided, he will receive financial support. Further details are specified by Reich law.

\section{Article 164}

The interests of the self-employed in agriculture, industry and trade are to be promoted in legislation and administration, and they are to be protected against takeover and overburdening.

\section{Article 165}

Workers and employees are called upon to participate, on an equal footing and in cooperation with the employers, in the regulation of wages and working conditions as well as in the economic development of productive forces. The organizations formed by both sides and their mutual agreements are recognized.

Workers and employees are granted, in order to represent their social and economic interests, legal representations in Enterprise Workers' Councils as well as in District Workers' Councils, organized for the various economic areas, and in a Reich workers' council.

District workers' councils and the Reich workers' council, in order to fulfill the economic tasks and to execute the socialization laws in cooperation with the employers, join District economic councils and a Reich economic council, in which the employers' representatives and other concerned circles also participate.

The district economic councils and the Reich economic council are to be organized in such a way, that all important professions are represented according to their economic and social importance.

Basic law drafts of social-political and economic character are to be presented by the Reich government to the Reich economic council for approval, before they are presented to Reichstag. The Reich economic council is entitled to propose such law drafts. If the Reich government does not approve to such a draft, it has to present the draft to Reichstag, accompanied by an explanation of its diverting position. The Reich economic council is entitled to have one of its members represent the draft in the Reichstag.

Supervision and administration authority may be transferred to the workers' and economic councils within the area they are responsible for.

The regulation of consistence and tasks of the workers' and economic councils, as well as their relation to other bodies of self-administration is exclusively a Reich matter.

\section{Transition and Final Decrees}

\section{Article 166}

The Reich court will establish an election supervision court in lieu of the Reich administration court, until the latter is established. 


\section{Article 167}

The regulations of Article 18 Paragraphs 3 and 6 will take force only 2 years after the proclamation of the Reich constitution.

In the Prussian province of Upper Silesia, within two months after the German administration will have taken control of the currently occupied area, a plebiscite will be held according to article 18 paragraph 4.1 and paragraph 5, answering the question if a separate state of Upper Silesia shall be formed.

If this question is affirmed, the state has to be created immediately, without the necessity to pass a Reich law. Following conditions have to be observed :

1. a state assembly has to be elected, which, within 3 months after the proclamation of the official final result of the plebiscite, has to form a state government and to call for the vote on a state constitution. The Reich president will decree election regulations according to the Reich election law, and will fix a day for the election.

2. The Reich president, in agreement with the Upper Silesian state assembly, will determine when the state is to be regarded as established.

3. All those acquire Upper Silesian nationality who :

a) are adult Reich nationals who reside or permanently dwell in Upper Silesia on the day the state is established

b) other adult Prussian nationals who have been born in Upper Silesia and who declare within a year of the establishment of the state that they desire to acquire Upper Silesian nationality

c) all Reich nationals who follow persons listed under a or by by birth, legitimation or marriage

\section{Article 168}

Until the state law mentioned in article 63 is passed, but until July 1st 1921 at the latest, the Prussia will be represented in the Reichsrat by members of the Reich government.

\section{Article 169}

The time when article 83 paragraph 1 will take force will be determined by the Reich government.

Within an adequate transition period the raise and administration of customs and consuption taxes may be left to the states, at their request.

\section{Article 170}

The Bavarian and Württemberg postal and telegraph services will be transferred to the Reich, on April 1st 1921 at the latest.

If no agreement over the conditions of the transfer have been made by October 1st 1920, the Reich supreme court will decide.

Until the transition Bavaria's and Württemberg 's traditional rights and obligations remain in force. Postal and telegraph connections with foreign countries are to be handled by the Reich exclusively.

\section{Article 171}

State railways, waterways and navigational aids are transferred into Reich property by April 1st 1921, at the latest.

Unless no agreement has been achieved regarding the transfer, the supreme court will decide. 


\section{Article 172}

Until the law concerning the supreme court takes force, its authority is exercised by a Senate of seven members, four of whom are delegated from Reichstag, three from Reichsrat. It regulates its own procedures.

\section{Article 173}

Until a Reich law will be proclaimed according to article 138, present state disbursements to religious organizations, based on law, treaty or other legal titles, will continue.

\section{Article 174}

Until a Reich law will be proclaimed according to article 146 paragraph 2 the present legal situation will remain valid. The law has to give special consideration to Reich areas where schools are not organized according to confessions.

\section{Article 175}

The specifications of article 109 to not apply to orders and medals which were awarded for merits in the war years 1914-1919.

\section{Article 176}

All public servants and Wehrmacht dependents are to take an oath on this constitution. Further details are to be determined by the Reich president.

\section{Article 177}

Where, in existing laws, it is stipulated that an oath has to include a religious formula, the oath also may be taken by the swearing person, while omitting the religious formula, declares : "I swear". Otherwise the oath formula as stipulated in the laws remains unchanged.

\section{Article 178}

The constitution of the German Reich of April 15th 1871 and the law concerning temporary Reich administration are suspended.

The other Reich laws and decrees remain in force, unless they contradict the constitution. The stipulations of the peace treaty signed on June 28th 1919 are not affected by this constitution. Concerning the negotiations on the acquisition of the island of Helgoland an agreement with the native population diverting from article 17 paragraph 2 may be reached.

Official decrees, which were formulated on hitherto valid law remain valid until they are suspended by other decrees or by legislation.

\section{Article 179}

Inasmuch laws or decrees refer to institutions which have been abolished by this constitution, the respective regulations and institutions described in this constitution take their place. Expressis verbis the national assembly is succeeded by the Reichstag, the state committee by the Reichsrat, the president elected according to the law on preliminary Reich government by the president elected in accordance with this constitution.

The authority hitherto of the state committee regarding the right to sign decrees is transferred to the Reich government; Reich government decrees require the approval of Reichsrat, in accordance with this constitution. 


\section{Article 180}

Until the first Reichstag will convene, this national assembly is regarded as Reichstag. The Reich president elected by the national assembly will serve in office until June 30th 1925.

\section{Article 181}

The German people, by the means of its national asembly, has passed and ratified this constitution. It takes force on the day of its proclamation. 


\subsection{Decreto do Incêndio do Reichstag, 28 de fevereiro de $1933^{228}$.}

\section{Order of the Reich President for the Protection of People and State}

On the basis of Article 48 paragraph 2 of the Constitution of the German Reich, the following is ordered in defense against Communist state-endangering acts of violence:

$\S 1$. Articles 114, 115, 117, 118, 123, 124 and 153 of the Constitution of the German Reich are suspended until further notice. It is therefore permissible to restrict the rights of personal freedom [habeas corpus], freedom of opinion, including the freedom of the press, the freedom to organize and assemble, the privacy of postal, telegraphic and telephonic communications, and warrants for house searches, orders for confiscations as well as restrictions on property, are also permissible beyond the legal limits otherwise prescribed.

${ }^{228}$ http://www.reference.com/ consultado em 07/07/2009, às 15 h00 


\subsection{Ato do Reichstag de 23 de março de $1933^{229}$.}

\section{Law to Remedy the Distress of the People and the Nation (Enabling Act)}

The Reichstag has enacted the following law, which is hereby proclaimed with the assent of the Reichsrat, it having been established that the requirements for a constitutional amendment have been fulfilled:

\section{Article 1}

In addition to the procedure prescribed by the constitution, laws of the Reich may also be enacted by the government of the Reich. This includes the laws referred to by Articles 85 Paragraph 2 and Article 87 of the constitution ${ }^{230}$.

\section{Article 2}

Laws enacted by the government of the Reich may deviate from the constitution as long as they do not affect the institutions of the Reichstag and the Reichsrat. The rights of the President remain undisturbed.

\section{Article 3}

Laws enacted by the Reich government shall be issued by the Chancellor and announced in the Reich Gazette. They shall take effect on the day following the announcement, unless they prescribe a different date. Articles 68 to 77 of the Constitution do not apply to laws enacted by the Reich government ${ }^{231}$.

\section{Article 4}

Treaties of the Reich with foreign states which affect matters of Reich legislation shall not require the approval of the bodies of the legislature. The government of the Reich shall issue the regulations required for the execution of such treaties.

\section{Article 5}

This law takes effect with the day of its proclamation. It loses force on 1 April 1937 or if the present Reich government is replaced by another.

\footnotetext{
${ }^{229}$ http://www.reference.com/ consultado em 07/07/2009, às 15h00.

${ }^{230}$ Article 85 outlined the process by which the Reichstag and Reichsrat approved the Reich budget. Article 87 restricted government borrowing.

${ }^{231}$ Articles 68 to 77 stipulated the procedures for enacting legislation in the Reichstag.
} 


\subsection{Discurso de Adolf Hitler em 23 de Março de $1933^{232}$}

\section{No Reichstag, Berlim}

\section{O Discurso}

"Em novembro de 1918, as organizações marxistas apossaram-se do poder executivo por meio de uma revolução. Os monarcas foram destronados, as autoridades do Reich e dos Estados afastados do governo, violando-se, portanto, a Constrição. O sucesso da revolução no sentido material protegeu os partidos culpados contra a ação da lei. Procuraram justificar moralmente tal cousa afirmando que a Alemanha ou seu governo fora responsável pela irrupção da guerra.

"Esta asserção era deliberada e possivelmente mentirosa. Em conseqüência dela, todavia,estas acusações mentirosas feitas no interesse dos nossos antigos inimigos levaram à mais severa opressão de toda a nação alemã e à quebra das garantias que nos foram dadas pelos quatorze pontos de Wilson, e assim lançaram a Alemanha, isto é as classes trabalhadoras do povo alemão, numa época de infinita desgraça...”

"A divisão da nação em grupos com opiniões inconciliáveis, provocada sistematicamente pelas doutrinas falsas do marxismo, significa a destruição da base de uma possível vida comunal...É somente a criação de uma verdadeira comunidade nacional, erguendo-se acima dos interesses e das diferenças de classe, que pode fechar permanentemente a fonte de nutrição de tais aberrações do espírito humano. $\mathrm{O}$ estabelecimento dessa solidariedade de opiniões no corpo da nação e tanto mais importante quanto só por esse meio é que surge possibilidade de manutenção de relações amigas com potencias estrangeiras, independentemente das tendências ou princípios gerais por que se governem, pois a eliminação do comunismo na Alemanha é uma assunto puramente interno.

"Simultaneamente com essa política de purificação de nossa vida pública, o governo do Reich procederá um inteiro expurgo moral do corpo da nação. Todo sistema educacional, o teatro, o cinema a literatura a imprensa e o rádio- tudo será empregado como um meio para este fim e dessa forma avaliado. Todos estes elemento devem servir para a manutenção dos valores eternos presentes no caráter essencial de nosso povo. A arte sempre ficará sendo a expressão e o reflexo dos anseios e das realidades de uma época. Atitude neutral e internacional de alheiamento está desaparecendo rapidamente. O heroísmo avançará apaixonadamente e no futuro moldará e norteará o destino político. A tarefa da arte é ser a expressão desse espírito determinante da época. Sangue e raça serão mais uma vez fonte da intuição artística..."

"Nossas instituições legais devem servir acima de tudo para a manutenção dessa comunidade nacional. A inamovibilidade dos juízes deve assegurar um senso de responsabilidade e o exercício da discreção nos seus julgamentos dentro do interesse da sociedade. Não o indivíduo mas somente a nação como um todo é que pode ser o centro da solicitude legislativa. A alta traição e a perfídia para com a nação serão no futuro impiedosamente extirpadas. Os fundamentos da existência da justiça não podem ser outros senão os fundamentos da existência da nação.

"O governo, resolvido a proceder a purificação moral e política de nossa vida pública, está criando e mantendo as condições necessárias para um renascimento verdadeiramente profundo da vida religiosa.

${ }^{232}$ HITLER, Adolf, Op. cit., 1943, p. 123. 
“As vantagens da natureza política e pessoal que possam surgir de transigência com organizações ateísticas não sobrepujarão as conseqüências que surgiriam com a destruição dos valores morais básicos gerais. O governo nacional considera as duas religiões cristãs como os mais ponderáveis fatores para a manutenção de nossa nacionalidade. O governo respeitará os acordos concluídos entre ele e os Estados Federais. O direitos deste não serão infringidos. Mas o governo confia e espera que o trabalho de regeneração moral e nacional de nossa nação, a tarefa que ele se impôs, seja, por outro lado, tratada com o mesmo respeito..."

"Grandes são as tarefas do governo nacional na esfera da vida econômica.

"Aqui todas as ações devem ser governadas por uma lei: o povo não vive para o comércio e o comércio não existe para o capital, mas o capital serve o comercio e o comércio serve o povo. Em princípio o governo não protegerá os interesses econômicos do povo alemão pelo método tortuoso de uma burocracia econômica a ser organizada pelo Estado, mas pelo máximo fomento da iniciativa particular e pelo reconhecimento dos direitos de propriedade ..."

“Ademais, é perfeitamente claro para o governo nacional que a debelação final das dificuldades, tanto no comercio agrícola como no das cidades, depende da absorção do exército dos desempregados no processo de produção. Esta constitue a segunda das grandes tarefas econômicas. Ela só pode ter solução como uma satisfação geral, na aplicação de princípios econômicos sãos e naturais e de todas as mediadas necessárias, mesmo que, no momento, elas não possam contar com qualquer grau de popularidade. O oferecimento de trabalho e a contribuição obrigatória de serviço dão, a este respeito, apenas medidas individuais dentro do âmbito de toda a proposta..."

"Temos presente que a posição geográfica da Alemanha, com a sua falta de matérias primas, não permite inteiramente a autonomia econômica do Reich. Nunca será demasiado afirmar que nada esta mais longe do pensamento do governo do Reich do que a hostilidade para com a exportação. Estamos plenamente advertidos de que necessitaremos da ligação com o mundo exterior, e que a colocação dos produtos alemães no mercado mundial assegura a existência de muitos milhões de nosso concidadãos.

“Também sabemos quais são as condições necessárias para uma boa troca de serviços entre as nações do mundo. Porque a Alemanha como um participante ativo na troca de produtos não pertence tanto a política comercial como a política financeira. Enquanto não nos concedem uma amortização razoável da nossa dívida estrangeira em correspondência com a nossa capacidade de produção, somos degraçadamente compelidos a manter nosso controle cambial estrangeiro. O governo do Reich também é, por esse motivo, obrigado a manter as restrições ao escoamento do capital fora das fronteiras da Alemanha.

“A proteção das fronteiras do Reich e,portanto, da vida de nosso povo e da existência de nosso comércio está agora nas mãos do Reichswehr, que, de acordo com os termos que nos foram impostos pelo Tratado de Versalhes, deve ser considerado o único exército verdadeiramente desarmado do mundo. A despeito de sua pequenez forçada e do seu armamento completamente ineficiente, o povo alemão deve olhar para a sua Reichswehr com orgulhosa satisfação. Esse pequeno instrumento de nossa defesa nacional surgiu dentro das mais difíceis condições. O espírito de que ele está imbuído é o das nossas melhores tradições militares. A nação alemã tem,pois, tem cumprido com dolorosa concienciosidade as obrigações que lhe foram impostas pelo Tratado de Paz; com efeito, até a substituição então sancionada dos navios de nossa frota, infelizmente, talvez me seja permitido dizer, foi apenas realizada em pequena parte. 
"Durante anos a Alemanha tem esperado em vão o cumprimento das promessas de desarmamento que lhe foram feitas pelos outros. É desejo sincero do governo nacional poder abster-se de aumentar o nosso exercito e as nossas armas, desde que o resto do mundo também esteja pronto para cumprir agora suas obrigações em matéria de desarmamento radical. Porque a Alemanha não deseja outra cousa além de um direito igual para viver em igual liberdade.

"Em qualquer caso, o governo nacional educará o povo alemão neste espírito de desejo de liberdade. A honra nacional, a honra do nosso exercito e o ideal de liberdade devem mais uma vez ser sagradas para o povo alemão!

“A nação alemã deseja viver em paz com o resto do mundo. Mas é por esta mesma razão que o governo do Reich empregará todos os meios para obter o termo final das divisões das nações do mundo em duas categorias. O manter aberta essa ferida leva a desconfiança de um lado e ao ódio de outro, e desta forma a um sentimento geral de insegurança. O governo nacional está pronto a estender a mão em sincero entendimento a todas as nações que finalmente estejam dispostas a por um termo ao trágico passado. A dificuldade econômica internacional só poderá desaparecer quando forem estabelecidas as bases de relações políticas estáveis e quando as nações tenham recuperado a sua confiança mútua.

"Para vencer a catástrofe econômica três cousas são necessárias:

“1. Governo absolutamente autoritário nos assuntos internos, afim de criar confiança na estabilidade das condições.

"2. A garantia, pelas grande nações, de uma paz duradoura, afim de restaurar a confiança entre as nações.

"3. A vitória final dos princípios do bom senso na organização e orientação do comércio, e também um desobrigação geral nas reparações e responsabilidades impossíveis pelas dividas e juros.

"Defronta-se-nos infelizmente o fato de que a Conferência de Genebra, a despeito de longas negociações, não chegou ate agora a nenhum resultado prático. A decisão concernente à garantia de uma medida real de desarmamento tem sido constantemente protelada por questões de detalhes técnicos e pela introdução de problemas de que nada tem a ver com o desarmamento. Essa tática é inútil.

"A condição ilegal do desarmamento unilateral e a resultante insegurança nacional da Alemanha não pode continuar por mais tempo.

Reconhecemos como um sinal de senso de responsabilidade e da vontade do governo inglês o fato de que tenha procurado, por intermédio da proposta de desarmamento, levar a Conferência a alcançar finalmente soluções rápidas. O governo do Reich apoiará qualquer esforço para a verdadeira execução de um desarmamento geral. Durante quatorze anos estivermos desarmados, e durante quatorze meses estivemos a esperar os resultados da Conferência do Desarmamento. De muito maior alcance é o plano do chefe de governo italiano, que faz uma tentativa esclarecida e vasta para conseguir um desenvolvimento pacífico e coerente de toda a política européia. Damos a maior importância a este plano, e estamos prontos a cooperar com absoluta sinceridade dentro das bases por ele estabelecidas, afim de unir as quatro Grandes Potências. Inglaterra, França, Itália e Alemanha, numa cooperação antiga para atacar com resolução e coragem os problemas de cuja solução depende o destino da Europa.

"É por esta razão que somos particularmente gratos pela sinceridade apreciativa com que o renascimento nacional da Alemanha tem sido recebido pela Itália...”

"Do mesmo modo, o governo do Reich, que considera o cristianismo como fundamento inabalável da moral e do código moral da nação, empresta o maior valor as relações de amizades com a Santa Fé, e esforça-se por desenvolvê-las. Sentimos simpatia para com 
a nossa irmã Áustria nas suas perturbações e dificuldades. Em tudo o que faz o governo alemão esta consciente da conexão existente entre o destino de todas as raças germânicas. Sua atitude para com as outras potências estrangeiras pode ser depreendida do que já foi dito. Mas até no caso de que as nossas relações estejam assoberbadas de dificuldades, procuraremos chegar a um entendimento. Mas em caso algum as bases para a compreensão jamais poderão ser distinção entre vencedores e vencido.

"Estamos convencidos de que tal entendimento é possível em nossas relações com a França, se os governos atacarem os problemas que as atingem em ambos os lados, fazendo-o de maneira esclarecida. O governo do Reich está pronto para cultivar com a União Soviética relações amigas proveitosas a ambas as partes. É acima de tudo o governo da Revolução Nacional que se sente em posição de adotar semelhante política positiva para com a União Soviética. A luta contra o comunismo na Alemanha é nosso assunto interno no qual jamais permitiremos interferência do exterior...”

"Levamos particularmente a peito o destino dos alemães que vivem fora das fronteiras da Alemanha e nos estão ligados pela fala, cultura e costumes, e têm de lutar duramente para manter esses valores. O governo nacional está disposto a usa todos os meios ao seu alcance para defender os direitos internacionalmente garantidos as minorias alemãs.

"Recebemos de bom-grado o plano para a Conferência Econômica Mundial e aprovamos a reunião em data próxima. O governo do Reich está pronto a tomar parte dessa conferência, afim de que finalmente se chegue a resultados positivos...” 